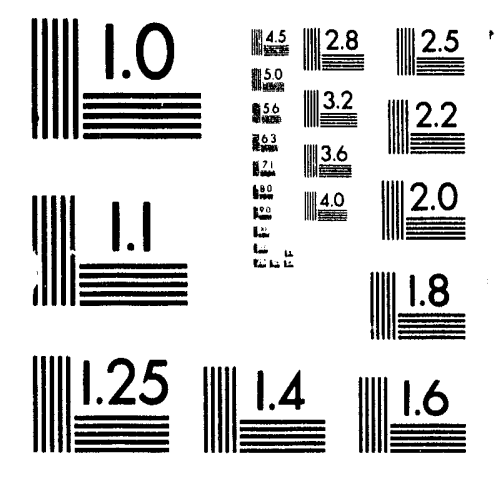



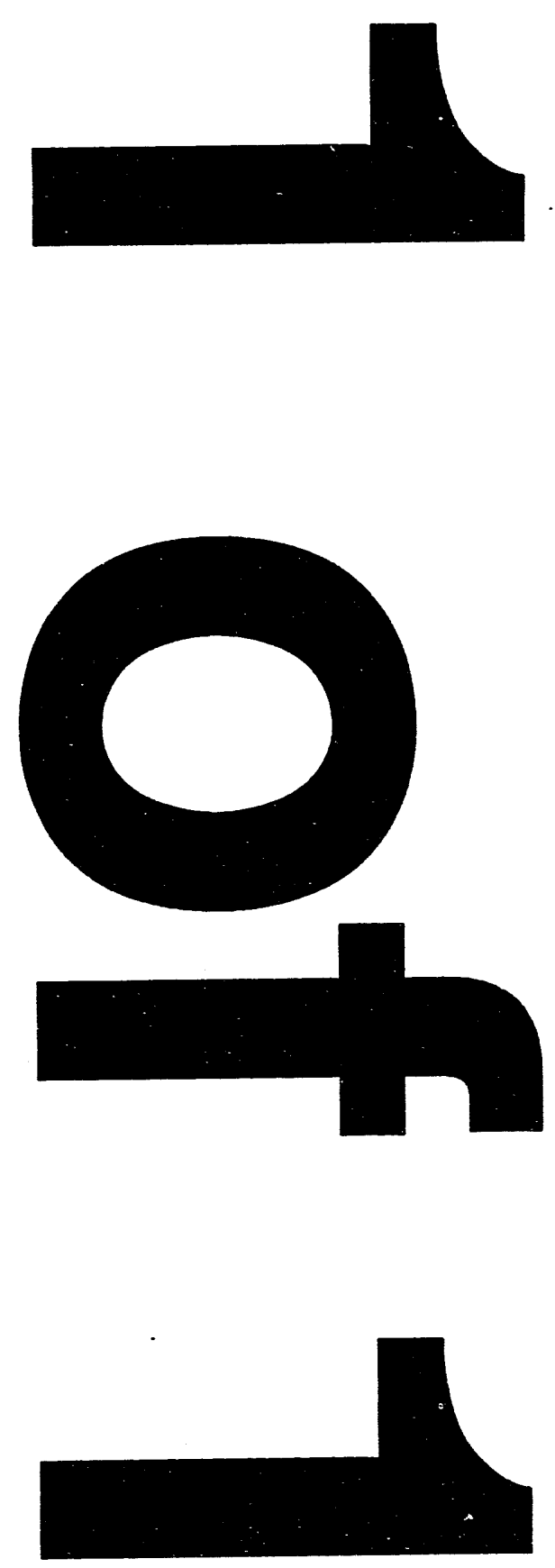


\section{FINAL EXAMINATION OF IDMS CORROSION COUPONS (U)}

by

K. J. Imrich

Westinghouse Savannah River Company

Savannah River Site

Aiken, South Carolina 29808

C. F. Jenkins
05027933

OSTI

This paper was prepared in connection with work done under the above contract number with the U.S.

Department of Energy. By acceptance of this paper, the publisher and/or recipient acknowledges the U.S.

Government's right to retain a nonexclusive, royalty-free license in and to any copyright covering this paper, along with the right to reproduce and to authorize others to reproduce all or part of the copyrighted paper. 


\section{DISCLAIMER}

This report was prepared as an account of work sponsored by an agency of the United States Government. Neither the United States Government nor any agency thereof, nor any of their employees, makes any warranty, express or implied, or assumes any legal liability or responsibility for the accuracy, completeness, or usefulnezs of any information, apparatus, product, or process disclosed, or represents that its use would not infringe privately owned rights. Reference herein to any specific commercial product, process, or service by trade name, trademark, manufacturer, or otherwise does not necessarily constitute or imply its endorsement, recommendation, or favoring by the United States Government or any agency thereof. The views and opinions of authors expressed herein do not necessarily state or reflect those of the United States Government or any agency thereof.

This report has been reproduced directly from the best available copy.

Available to DOE and DOE contractors from the Office of Scientific and Technical Information, P. O. Box 62, Oak Ridge, TN 37831; prices available from (615) $576-8401$.

Available to the public from the National Technical Information Service, U. S. Department of Commerce, 5285 Poit Royal Rd., Springfield, VA 22161 
WSRC-TR-93-461

FINAL EXAMINATION OF IDMS CORROSION COUPONS (U)

By

K. J. Imrich

and

C. F. Jenkins

September 16, 1993

\section{Westinghouse Savannah River Company \\ P.O. Box 616 \\ Aiken, SC 29802}

Prepared For The U.S. Department Of Energy Under Contract DE-AC09-89SR18035 
September 16, 1993

\section{BUBJECT DESCRIBERS}

IDMS

Corrosion

Coupon

Evaluation

DWPF

T-Area

Retention: Lifetime

To: J.R. Zamecnik, 704-1T

Defense Waste Processing Technology

WSRC-TR-93-461

From: K.J. Imrith \& C.F. Jenkins

Materials Technology Section

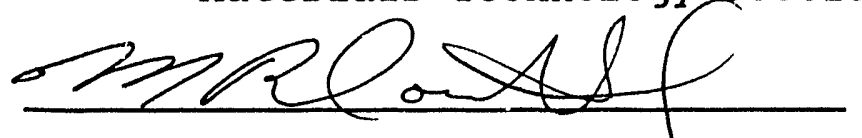

M.R. Louthan Jr., Technical Reviewer

Materials Technology Section

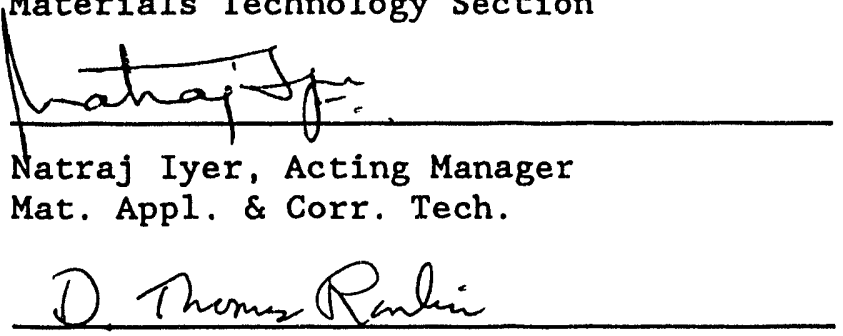

D.T. Rankin, Authorized Derivative Classifier

Materials Technology Section

FINAL EXAMINATION OF IDMS CORROSION COUPONS (U)

\section{summary}

The metallurgical examination of corrosion coupons removed from the Integrated DWPF Melter System (IDMS) was performed as part of the IDMS Materials Evaluation Program. The findings and conclusions of the evaluation program are as follows:

1) No corrosive attack or abnormal wear was observed on coupons in the IDMS Feed Preparation System, including Hastelloy C-276. Exposure represents approximately 4 months ( $1 / 3$ of the anticipated annual throughput) of DWPF operation. An internal inspection of the IDMS Slurry Receipt Adjustment Tank/Slurry Mix Evaporator (SRAT/SME) and Melter Feed Tank is necessary to fully assess any abrasive damage. 
J. R. Zamecnik, 704-T

September 16,1993

Page 2 of 65

WSRC-TR-93-461

2) All coupons in the Quencher Inlet region of the off-Gas system exhibited localized corrosion. Exposure was continuous, representing four years of DWPF operation. Alloys 690 and Al loorr, which are used in DWPF off-Gas system, experienced significant corrosive attack, but not sufficient to affect operating life. Alloys C-22 and 625 exhibited superior corrosion resistance and must be considered for the next generation Quencher.

3) Pitting was observed in the austenitic stainless steel coupons in the off-Gas Condenser vapor inlet and the HEME inlet locations downstream of the Quencher. The IDMS units are of stainless steel construction and inspection for possible damage is recommended. Similar DWPF components are fabricated from Hastelloy C-276 and are not subject to corrosion in this environment.

4) Corrosion coupons from the Melter have not yet been removed for metallurgical examination. These examinations should be performed at the earliest possible time.

\section{Background}

Materials Technology section (MTS) was requested by Defense Waste Processing Technology (DWPT) to examine corrosion coupons removed from the IDMS as part of the IDMS Materials Evaluation Program. This program was established to confirm the performance of Defense Waste Processing Facility (DWPF) reference materials of construction and other to evaluate alternate materials. Generally, the alternate materials are more highly alloyed, and therefore, expected to be more corrosion resistant. The various materials exposed during this study are 1 isted in Table 1.

The IDMS consists of two major portions, the Feed Preparation system and the Melter/Off-Gas system. In addition to the current evaluation, an initial characterization ${ }^{2,3}$ and an interim visual inspection ${ }^{4}$ of the corrosion coupons were conducted as part of the IDMS Materials Evaluation Program. Coupons selected for this study were placed throughout the IDMS and consisted of standard flat and U-bend specimens. Some of the coupons were welded with matching filler metal and are designated with a "W" in the coupon identification number. In order to evaluate the effects of crevice corrosion, crevice washers were used on most specimens. In addition, coupons were inspected for evidence of general corrosion, pitting, stress corrosion cracking, and abrasive wear.

Removal of all corrosion racks except those from the melter and melter stack was performed in April, 1993. The following list contains the locations of the thirteen corrosion racks which were evaluated as part of this study (Figure 1): 
J. R. Zamecnik, 704-T

September 16,1993

Page 3 of 65

WSRC-TR-93-461

\section{Feed Preparation system}

1a) Slurry Receipt Adjustment Tank and Slurry Mix Evaporator (SRAT/SME) - Vapor Space,

1b) SRAT/SME - Liquid/Vapor Zone,

2) SRAT/SME Condenser - Vapor Inlet,

3) Mercury Water Wash Tank (MWWT) - Vapor Space,

4a) Melter Feed Tank - Vapor Space,

4b) Melter Feed Tank - Liquid/Vapor Zone,

Melter/Off-Gas System
5) Quencher - Inlet,
6) Quencher - outlet,
7a) Off-Gas Condensate Tank (OGCT) - Vapor Space,
7b) Off-Gas Condensate Tank - Liquid Zone,
8) Off-Gas Condenser - Vapor Inlet,
9) Off-Gas Condenser - Drain,
10) Steam Atomized Scrubber (SAS) - Drain Line,
11) High Efficiency Mist Eliminator (HEME) - Inlet,
12) HEME - outlet, and
13) High Efficiency Particulate Air (HEPA) Filter - Inlet.

\section{Operating History}

The Feed Preparation system and the Melter system have been exposed to a total of 20 batches of sludge and frit since the system was started in April, 1989. Sixteen of the batches were processed prior to the interim visual inspection in January, 1992. Sludge for the 16 tests contained reference levels of all materials, including halides and sulfates. Nominal compositions of several of the sludge-slurry feed simulants are presented in Table 2. Mercury, noble metals, selenium (Se) and tellurium ( $\mathrm{Te}$ ) were added to several of the batches. The following lists the sludge-slurry types used for the various test runs processed in IDMS between 1989 and 1992:

- Coupled Feed Runs ${ }^{5} 1,2$, and 3:

- Batch 1 type sludge was used for all three runs.

- Mercury Runs6 1, 2, and 3:

- Batch 1 type sludge with approximately $1.2 \%$ mercury, was used for all three runs.

- Blend Runs 1 and 2:

- Blend type sludge was used in both runs with se, Te and noble metals all at reference levels together with mercury at approximately $1.6 \%$. 
J. R. Zamecnik, 704-T

September 16, 1993

Page 4 of 65

WSRC-TR-93-461

- Blend Run 3 :

- Blend type sludge with no mercury additions.

- H Modified (HM) Run 1:

- HM type sludge with no mercury.

- HM Runs 2 and 3 :

- HM type sludge with Se, Te and noble metals all at reference levels. Sludge for these runs contained no mercury.

- Purex Runs 1 and 2:

- Purex type sludge with Se, Te and noble metals all at HM sludge (or high heat purex) reference levels. Sludge for these runs contained no mercury.

- Hanford Runs ${ }^{9} 1$ and 2:

- Hanford type sludge which contained noble metals at reference levels and no mercury.

For mercury runs 1,2 , and 3 , the concentration of $\mathrm{Hg}\left(\mathrm{NO}_{3}\right)_{2}$ in the SRAT/SME condenser condensate was up to $11,000 \mathrm{mg} / \mathrm{liter}$. The mercury in the melter feed ranged from 6 to $37 \mathrm{mg} / \mathrm{liter}$. The concentration of mercury compounds in the melter off-gas condensate was up to 15 $\mathrm{mg} / \mathrm{liter}$. Analyses indicated that mercury existed primarily as Hgo or $\mathrm{HgCl}_{2}$ while lower concentrations of metallic $\mathrm{Hg}$ and $\mathrm{Hg}_{2} \mathrm{Cl}_{2}$ were present 6 . These concentrations are consistent with those anticipated in DWPF.

After the interim visual inspection was conducted in January, 1992, four additional runs were completed, three of which were fed to the melter. All of these runs were processed using the nitric acid flow sheet. Two of the runs were with hydroxylamine nitrate (HAN) type Precipitate Hydrolysis Aqueous (PHA) and two were with simulated Late Wash PHA. Noble metals were at HM sludge concentrations and mercury was nominally 3.2 wto on a dry (solids only) basis. The sludges used for the four runs were one HM type and three Purex types.

The IDMS has been in operation for approximately 4 years during which a total of 20 batches of sludge have been processed as described above. In comparison, DWPF anticipates processing approximately 70 batches of sludge per year, approximately $75 \%$ of full operating capacity, without a significant amount of idle time. During the 4 years there has been much idle time in which sludge was not being prepared and fed to the melter. However, while the Feed Preparation System was down, the melter was maintained at operating temperature (vapor space temperature 
J. R. Zamecnik, 704-T

September 16,1993

Page 5 of 65

WSRC-TR-93-461

$800^{\circ} \mathrm{C}$ ) and contained a full charge, approximately $6 \mathrm{ft}^{3}$, of molten glass from the previous batch. Most of the corrosive species, which would normally have been entrained in the vitrified glass, were volatilized and exited the melter through the off-Gas system. This may represent a slightly more corrosive environment.

\section{Observations And Test Results}

As part of this investigation all coupons were photographed before and after cleaning. Cleaning was performed in accordance with ASTM G1 ${ }^{10}$. In most cases the use of a soft brush with light pressure and mild soap mixed with domestic water was sufficient to remove any deposits. Coupons requiring additional cleaning to remove deposits or elemental mercury were immersed for several minutes in a $5 \%$ nitric acid solution at room temperature.

Coupon evaluation included visual and microscopical examinations, dye penetrant testing and weight change measurements. Destructive metallography was performed on only those coupons that showed evidence of significant corrosive attack or wear. Visual and microscopic examinations of the coupons included inspection of the areas beneath the crevice washers, in the fusion and heat affected zones of the welds and in the parent metal including the edges of the coupons. Dye penetrant tests were performed and documented by site services Quality/Quality Control (SSQ/QC) ${ }^{11,12}$. These tests were performed to identify any surface flaws, including stress corrosion cracks, which may have resulted from exposure to the different IDMS process environments. All observations and test results will be presented in this document on a rack by rack basis. Data was recorded in Lab Notebook WSRC-NB-93-30.

\section{SRAT/BME (Vapor space And Liquid/Vapor Zone)}

Coupon Rack And Washer Material: Hastelloy C-276 / Teflon crevice washers on all coupons.

Visual Examination Before cleaning: Coupons were covered with hard brownish deposits from the slurry. The deposit was packed tightly between the coupons. Elemental mercury was observed on all coupons (Figures 2 and 3 ). The coupons were difficult to clean with mild soap and water and therefore required additional cleaning in dilute nitric acid.

Visual And Microscopic Examination After cleaning: Slight brown stains remained on some samples. Grinding marks from the initial fabrication were still clearly visible on all samples. No general or crevice corrosion or pitting attack was evident on any of the coupons (Figure 4 ). 
J. R. Zamecnik, 704-T

September 16, 1993

Page 6 of 65

WSRC-TR-93-461

Weight And Dimensions: No significant weight or dimensional change was observed for any of the coupons (see Table 3 and 4).

Dye penetrant Tests: No indication of any surface flaws was noted.

Metallography And scanning Electron Microscope (8EM):

Examinations were not necessary.

SRAT/SME Condenser (Vapor Inlet)

Coupon Rack And Washer Material: Hastelloy C-276 / Teflon crevice washers on all coupons.

Visual Examination Before cleaning: Coupons were coated with a thin brown layer. This layer was adherent and required extra pressure during the cleaning with mild soap and water. No elemental mercury was observed on these specimens (Figure 5).

Visual And Microscopic Examination After cleaning: A thin dark brown deposit remained after cleaning. Grinding marks from the initial fabrication were still clearly visible on all samples. No pitting attack, general or crevice corrosion was evident on any of the specimens (Figure 6).

Weight And Dimensions: No significant weight or dimensional change was noted for any of the coupons (see Table 3 and 4).

Dye Penetrant Tests: No indication of any surface flaws was noted.

Metallography And 8EM: Examinations were not necessary.

Mercury Water Wash Tank (Vapor space)

Coupon Rack And washer Material: Type 304L / Teflon crevice washers on all coupons.

Visual Examination Before cleaning: Coupons were coated with a dark brown, almost black, deposit. Elemental mercury was evident on all coupons. A tar-like substance was observed on portions of these coupons (Figure 7).

Visual And Microscopic Examination After cleaning: Removal of the black tarry substance and the elemental mercury required additional cleaning in dilute nitric acid. Grinding marks from the initial fabrication were still clearly visible on all samples. The coupons did not exhibit any signs of general or crevice corrosion or pitting attack (Figure 8). 
J. R. Zameanik, 704-T

September 16,1993

Page 7 of 65

WSRC-TR-93-461

Weight And Dimensions: No significant weight or dimensional change was noted for any of the coupons (see Table 3 and 4).

Dye Penetrant Tests: No indication of any surface flaws was noted.

Metallography And sEM: Examinations were not necessary.

\section{Melter Feed Tank (Vapor Space And Liquid/Vapor zone)}

Coupon Rack And Washer Material: Hastelloy C-276 / Teflon crevice washers on all coupons.

Visual Examination Before cleaning: A brittle light brown coating was evident on coupons from both locations. The deposits were packed tightly between all the specimens. Coupons in the vapor region were not coated as heavily as those in the liquid/vapor region. The deposits did not appear to contain any elemental mercury (Figures 9 and 10).

Visual And Microscopic Examination After Cleaning: Coupons cleaned up well in mild soap and water. A very thin light brown stain remained on coupons from the liquid/vapor zone. Grinding marks from the initial fabrication were still clearly visible on all samples. Coupons did not exhibit any signs of general or crevice corrosion or pitting attack (Figure 11).

Weight And Dimensions: No significant weight or dimensional change was noted for any of the coupons (see Table 3 and 4).

Dye Penetrant Tests: No indication of any surface flaws was noted.

Metallography And SEM: Examinations were not necessary.

Quencher (Inlet)

Coupon Rack And Washer Material: Hastelloy C-276 / Flat ceramic washers on all coupons.

Visual Examination Before cleaning: Quencher inlet coupons were covered with a thick porous black soot-like material (Figure 12). This layer was easily removed with a soft brush but the metal surfaces remained discolored (blackened).

Visual And Microscopic Examination After Cleaning: An adherent thin black layer was visible on all the coupons from this rack even after cleaning using a soft brush with soap and water (Figure 13). The layer remained even after vigorous scrubbing 
J. R. Zamecnik, 704-T

September 16, 1993

Page 8 of 65

WSRC-TR-93-461

with a stiff bristle brush. Since these coupons may be examined in more detail in the future, further cleaning was not performed. Crevice corrosion, pitting and end-grain attack were evident on a number of these coupons, as indicated in Table 5. Photographs showing end-grain attack and general surface condition are shown in Figures 14 - 19. Pit depths, lengths and widths of representative pits are presented in Table 6.

Weight And Dimensions: All coupons experienced some weight loss; however, dimensional changes were not significant isee Table 3 and 4). The apparent inconsistency in the results is due to the highly localized nature of the attack.

Dye Penetrant rests: Indeterminate due to the amount of pitting on the samples.

Metallography And SEM: Photomicrographs and SEM images of the Inconel 690 and Allcorr samples are shown in Figures 20 and 21 . pitting and end-grain attack are shown.

Quencher (outlet)

Coupon Rack And washer Material: Hastelloy C-276/Teflon crevice washers on all coupons.

visual Examination Before cleaning: Coupons were coated with a very thin black glassy substance. Both grinding marks from the initial fabrication and identification marks could be seen under the coating (Figure 22 ).

Visual And Microscopic Examination After cleaning: A thin black coating remained on several of the coupons. Coupons did not exhibit any signs of general or crevice corrosion or pitting attack. End-grain attack was not observed on any coupon (Figure 23).

Weight And Dimensions: No significant weight or dimensional change was noted for any of the coupons (see Table 3 and 4).

Dye Penetrant Tests: No indication of any surface flaws was noted.

Metallography And sEM: Examinations were not necessary.

Off-Gas Condensate Tank (Vapor Space And Liquid Zone)

Coupon Rack And Washer Material: Hastelloy C-276/Teflon crevice washers on all coupons. 
J. R. Zamecnik, 704-T

September 16, 1993

Page 9 of 65

WSRC-TR-93-461

Visual Examination Before cleaning: These coupons were removed from the rack before they were documented. However, photographs of the coupons were taken before they were cleaned and are presented in Figures 24 and 25. A dark brown or black deposit was observed on coupons from both vapor and liquid regions.

Visual And Microscopic Examination After cleaning: Deposits were completely removed by cleaning with mild soap and water. Grinding marks from the initial fabrication were still clearly visible on all samples. Coupons did not exhibit any signs of general or crevice corrosion or pitting attack (Figure 26).

Weight And Dimensions: No significant weight or dimensional change was noted for any of the coupons (see Table 3 and 4).

Dye Penetrant Tests: No indication of any surface flaws was noted.

Metallography And SEM: Examinations were not necessary.

off-Gas Condenser (Vapor Inlet)

Coupon Rack And Washer Material: Hastelloy c-276/Teflon crevice washers on standard coupons, and flat Teflon washers on U-bend specimens.

Visual Examination Before cleaning: only small localized staining of these coupons was noted. The stains were light brown in color. Grinding marks from the initial fabrication were still clearly visible all samples (Figure 27).

Visual And Microscopic Examination After Cleaning: All stains were removed during cleaning with soap and water (Figure 28). Some pitting attack was observed under the flat washer on the $317 \mathrm{LW}$ (1) U-bend specimen. The pitting was not extensive and did not affect regions away from the washer (Figure 29). Other specimens on this rack did not show any signs of general, crevice or pitting corrosion.

Weight And Dimensions: Weight loss on the $317 \mathrm{LW}$ (1) U-bend specimen was not significant since the pitting was limited to only a small area under the washers. No significant weight or dimensional change was noted in any of the other coupons (see Table 3 and 4 ).

Dye Penetrant Tests: No indication of any surface flaws was noted.

Metallography And sEM: The extent of the pitting on the 317LW (1) U-bend specimen is shown in Figure 29a. Photomicrographs of the pitted region are shown in Figure 29b. No cracking was 
J. R. Zamecnik, 704-T

September 16, 1993

Page 10 of 65

WSRC-TR-93-461

observed inside the pits. Pit depths, lengths (longest dimension) and widths (shortest dimension) of representative pits are presented in Table 7.

Off-Gas Condenser (Drain)

Coupon Rack And washer Material: Hastelloy C-276 / Teflon crevice washers on standard coupons, and flat Teflon non-crevice washers on $\mathrm{U}$-bend specimens.

Visual Examination Before cleaning: only small localized staining of these coupons was noted. The stains were light brown in color (Figure 30).

Visual And Microscopic Examination After Cleaning: Stains were removed with mild soap and water. Grinding marks from the initial fabrication were still clearly visible all samples. The coupons did not exhibit any signs of general or crevice corrosion or pitting attack (Figure 31 ).

Weight And Dimensions: No significant weight or dimensional change was noted for any of the coupons (see Table 3 and 4).

Dye Penetrant Tests: No indication of any surface flaws was noted.

Metallography And sEM: Examinations were not necessary.

\section{Steam Atomized scrubber (Drain)}

Coupon Rack And washer Material: Hastelloy C-276 / Teflon crevice washers on all coupons.

Visual Examination Before cleaning: Coupons exhibited a light brown uniform coating. However, grinding marks from the initial fabrication were still clearly visible all samples (Figure 32 ).

Visual And Microscopic Examination After Cleaning: All deposits were removed by cleaning with soap and water. No evidence of general or crevice corrosion was observed on any of the coupons (Figure 33).

Weight And Dimensions: No significant weight or dimensional change was observed for any of the coupons (see Table 3 and 4 ).

Dye Penetrant Tests: No indication of any surface flaws was noted. 
J. R. Zamecnik, 704-T

September 16, 1993

Page 11 of 65

WSRC-TR-93-46I

Metallography And 8EM: Examinations were not necessary.

HEME (Inlet)

Coupon Rack And Washer Material: Hastelloy C-276/Teflon crevice washers on standard coupons, and flat Teflon non-crevice washers on U-bend specimens.

Visual Examination Before cleaning: Small localized reddish brown stains were visible on all the coupons. Grinding marks from the initial fabrication were still clearly visible on all samples (Figure 34 ).

Visual And Microscopic Examination After Cleaning: All stains were removed with soap and water (Figure 35). Pitting was observed under the flat washers on the $304 \mathrm{LW}$ (1) and $316 \mathrm{LW}$ (2) Ubend specimens, with pitting attack more severe on the 304 coupon (Figure 36). No pits were seen in the region outside the washers on either of these coupons. Pitting was more extensive on these coupons than on the $317 \mathrm{LW}$ coupon from the off-Gas Condenser. other coupons on this rack did not exhibit any signs of general or crevice corrosion or pitting attack.

Weight And Dimensions: Weight measurements of the $316 \mathrm{LW}$ (2) and $304 \mathrm{LW}$ (1) U-bend specimens showed some weight loss due to the pitting in the washer region. No significant weight or dimensional changes were noted for any of the other coupons (see Table 3 and 4 ).

Dye Penetrant Tests: No indication of any surface flaws was noted.

Metallography And SEM: No SCC was observed at the base of the pits in either of the coupons. Pit depths, lengths and widths of representative pits are presented in Table 8 .

HEME (outlet)

Coupon Rack And Washer Muterial: Type 316L / Teflon crevice washers on all coupons.

Visual Examination Before cleaning: only localized staining of these coupons was noted. Stains were reddish brown in color (Figure 37).

Visual And Microscopic Examination After cleaning: Stains were removed with mild soap and water. The coupons did not exhibit any signs of general or crevice corrosion or pitting attack

(Figure 38). 
J. R. Zamecnik, 704-T

September 16,1993

Page 12 of 65

WSRC-TR-93-461

Weight And Dimensions: No significant weight or dimensional change was noted for any of the coupons (see Table 3 and 4 ).

Dye Penetrant Tests: No indication of any surface flaws was noted.

Metallography And SEM: Examinations were not necessary.

HEPA (Inlet)

Coupon Rack And Washer Material: Type 316L / Teflon crevice washers on all coupons.

Visual Examination Before cleaning: A light haze was observed in several small areas on these coupons. Grinding marks from the initial fabrication were still clearly visible on all samples (Figure 39).

Visual And Microscopic Examination After cleaning: Haze was almost completely removed from all coupons. These coupons did not exhibit any signs of general or crevice corrosion or pitting attack (Figure 40 ).

Weight And Dimensions: No significant weight or dimensional change was noted for any of the coupons (see Table 3 and 4).

Dye Penetrant Tests: No indication of any surface flaws was noted.

Metallography And SEM: Examinations were not necessary •

\section{Discussion}

Coupons from the Feed Preparation System, including the SRAT/SME, SRAT/SME Condenser, MWWT and the MFT, exhibited no evidence of any form of corrosion or abnormal wear. However, coupons from the SRAT/SME and the MFT were heavily coated with solidified sludge/frit. This thick coating may act as a barrier to protect these coupons from both corrosive attack and abrasive wear. Abnormal wear of full scale equipment at TNX, i.e., agitator blades and coil supports, was observed previously ${ }^{13,14}$. Thus, a thorough internal inspection of the SRAT/SME vessel should be performed immediately.

To prevent the accumulation of sludge/frit on the coupons from the SRAT/SME and the MFT, the coupons should be spaced further apart. In addition, these racks should be cleaned prior to processing each new batch of sludge/frit. 
J. R. Zamecnik, 704-T

September 16, 1993

Page 13 of 65

WSRC-TR-93-461

Coupons from the Melter off-Gas System, in particular the Quencher Inlet, experienced various types of localized and general corrosive attack. Although the IDMS is run on an intermittent (batch) basis, the Melter and the off-Gas system are operated continuously. Therefore, the Quencher Inlet coupons have experienced approximately four years of exposure. Table 5 summarizes the various types of corrosion and the relative degree of attack observed on each of the coupons from the Quencher Inlet. In addition, the materials in the table are ranked based on performance, with pitting and crevice corrosion given the most weight, respectively. Localized attack was observed on the Inconel 690 and Teledyne-Allvac Allcorr coupons. This is significant since these materials are currently used in the DWPF off-Gas System, including the off-Gas Film Cooler and Quencher. The environment in this region of the system is severe, containing such corrosive species as $\mathrm{Cl}, \mathrm{F}$, sulfur and $\mathrm{SO}_{4}$ with temperatures in excess of $350^{\circ} \mathrm{C}^{15}$.

Based on the results of this study, Hastelloy c-22 and Inconel 625 possess superior corrosion resistance to the environment in the inlet region of the Quencher. Although Inconel 690 and Teledyne-Allvac Allcorr did not perform as well as Hastelloy $\mathrm{C}-22$ and Inconel 625, these alloys should meet the design life requirements in DWPF. Design life for the DWPF Melter is between 2 and 5 years while jumpers, including the one containing the quencher, are designed for up to 5 years of service life.

A visual examination of the IDMS off-Gas Film cooler and Quencher, which are fabricated from Inconel 690 and Hastelloy C-276 respectively, is recommended since additional information concerning the performance of these alloys under actual operating environments would be beneficial. This information is pertinent to DWPF since the DWPF offGas Film Cooler and the replacement Quenchers are fabricated from Inconel 690 and Hastelloy c-276, respectively.

The only other coupons from the Melter off-Gas system that showed any signs of localized or general corrosive attack were from the off-Gas Condenser Vapor Inlet and the HEME Inlet. Pitting was observed on the $317 \mathrm{~L}$ stainless steel coupon from the off-Gas condenser and on the $304 \mathrm{~L}$ and $316 \mathrm{~L}$ stainless steel coupons from the HEME Inlet. In each case these were the least corrosion resistant material on the corrosion racks. Hastelloy $\mathrm{c}-276$, the material of construction for these components in DWPF, suffered no degradation. Therefore, under conditions expected in the DWPF off-Gas Condenser and HEME, Hastelloy C-276 is expected to perform satisfactorily. However, because the IDMS components are fabricated from $304 \mathrm{~L}$ stainless steel, periodic inspections should be performed.

Corrosion coupons exposed in the melter, including the melter vapor and spray zones, were not examined at this time. They are attached to the melter thermowell and could not be removed due to an unknown 
J。R. Zamecnik, 704-T

September 16, 1993

Page 14 of 65

WSRC-TR-93-461

obstruction. Important material performance data would be acquired from evaluation of the various coupons exposed in this region, therefore, they should be removed and examined as soon as possible.

\section{Findings and Conclusions}

The findings presented in this investigation lead to the following conclusions:

1) No corrosive attack or abnormal wear was observed on any of the coupons from the Feed Preparation System in IDMS. Hastelloy C-276, the DWPF reference material of construction for the Feed Preparation system process vessels, should perform satisfactorily in DWPF. However, internal inspections of the IDMS SRAT/SME and MFT are still necessary to fully assess the abrasive behavior of the sludge/frit slurry.

2) Teledyne-Allvac Allcorr and Inconel 690 showed evidence of localized corrosive attack in the IDMS Quencher Inlet region. However, the degradation was not severe and would not be expected to result in a component failure in DWPF within the design life of the system.

Further inspection of IDMS off-Gas components, i.e., Film Cooler and Quencher, are necessary to fully assess the corrosion behavior of the Inconel 690 and Hastelloy c-276.

3) Hastelloy $\mathrm{C}-22$ and Inconel 625 exhibited superior resistance to localized corrosion compared to that of Inconel 690 and Allcorr in the Quencher Inlet region of the Melter off-Gas system. Consideration needs to be given to using these alloys for the next generation Quencher.

4) The pitting of the austenitic stainless steels (304L, 316L and 317L) from the off-Gas Condenser Vapor Inlet and the HEME Inlet is a concern in IDMS only. Corrosive attack of these regions in DWPF is not expected because DWPF components are fabricated from the more corrosion resistant Hastelloy $\mathrm{C}-276$.

\section{Recommendations}

The following are recommendations based on the results of this investigation:

1) Internal inspections of the IDMS SRAT/SME and MFT are required to fully assess the abrasive behavior of the sludge/frit slurry. Replacement coupons installed in the SRAT/SME and in the MFT should be spaced further apart to avoid accumulation of sludge. Furthermore, it is suggested that these coupon racks be cleaned prior to processing each new batch of sludge. 
J. R. Zamecnik, 704-T

September 16,1993

Page 15 of 65

WSRC-TR-93-461

2) The IDMS off-Gas Film Cooler and Quencher should be visually at the earliest opportunity inspected for signs of localized corrosion.

3) The IDMS off-Gas Condenser Vapor Inlet and the HEME Inlet should be visually inspected for indications of crevice and pitting corrosion.

4) The coupons exposed in the melter vapor space and spray zone should be removed as soon as possible for metallurgical evaluation.

\section{References}

1. S.M. Nordwick and J.R. Zamecnik, DWPT Task Plan IDMs Materials Inspections, DWPTQA-89-0042, Savannah River Site, Aiken, SC 29802 (December 12, 1989).

2. S.M. Nordwick, Equipment Engineering Division Area Metallurgical Report, IDMs Corrosion Coupons, EED890385, Savannah River Site, Aiken, SC 29802 (March 27, 1989).

3. M.E. Smith, N.D. Hutson, D.H. Miller, J. Morrison, H.B. Shah, J.A. Shuford, J. Glascook, F.H. Wurzinger, and J.R. Zamecnik, Checkout And startup of The Integrated DWPF Melter system (U), WSRC-RP-89321, Savannah River Site, Aiken, SC 29802 (November 11, 1989).

4. K.J. Imrich and J.R. Zamecnik, Examination of IDMs corrosion Coupons, EES920128, Savannah River Site, Aiken, SC 29802 (July 15, 1992).

5. J.A. Ritter, N.D. Hutson, M.E. Smith, M.K. Anderson, D.H. Miller, and J.R. Zamecnik, Integrated DWPF Melter system Campaign Raport Coupled Feed operation (U), WSRC-TR-90-131, Savannah River Site, Aiken, SC 29802 (March 1, 1990).

6. N.D. Hutson, J.R. Zamecnik, M.E. Smith, D.H. Miller, J.A. Ritter, Integrated DWPF Melter system (IDMS) Campaign Report - Mercury operation, WSRC-TR-91-0363, Savannah River Site, Aiken, SC 29802 (May 22, 1991).

7. N.D. Hutson, J.R. Zamecnik, M.E. Smith, D.H. Miller, and J.A. Ritter, Integrated DWPF Melter system (IDMB) Campaign Report - The First Two Noble Metals operations (U), WSRC-TR-91-0400, Savannah River Site, Aiken, SC 29802 (June 6, 1991).

8. J.R. Zamecnik, N.D. Hutson, M.E. Smith, D.H. Miller, and J.A. Ritter, Integrated DWPF Melter system (IDMS) campaign Report - DWPF Cold Run Demonstrations (U), WSRC-RP-93-593 Rev. 0, Savannah River Site, Aiken, SC 29802 (April 21, 1993).

9. N.D. Hutson, Integrated DWPF Melter system (IDMS) Campaign Report: Hanford Waste Vitrification Plant (HWVP) Process Demonstration (U), 
J. R. Zamecnik, 704-T

September 16, 1993

Page 16 of 65

WSRC-TR-93-461

WSRC-TR-92-0403 Rev. 0, Savannah River Site, Aiken, SC 29802 (August 10, 1992).

10. ASTM GI - 90, standard Practice For Preparing, cleaning And Evaluating Corrosion Test specimens, 1292 Annual Book of ASTM Standards, Vol. 3.02, 1992.

11. J.B. Livingston, Liquid Penetrant Examination Report, 93-IR-06-PT0792, Savannah River Site, Aiken, SC 29802 (June 25, 1993).

12. P. Smock, Liquid Penetrant Examination Report, 93-IR-06-PT-0838, Savannah River Site, Aiken, SC 29802 (July 12, 1993).

13. C.F. Jenkins, SRAT/8ME Components Wear, Area Metallurgical Report EED870106, Savannah River Site, Aiken, SC 29802 (March 25, 1987).

14. C.F. Jenkins, ETF slurry Hold Tank - Coil Failure, Area Metallurgical Report EED840027, Savannah River Site, Aiken, SC 29802 (January 13, 1984)

15. C.M. Jansen, Glass Melter off-Gas system Pluggages: Cause, significance, And Remediation (U), WSRC-TR-90-205 Rev. 0, Savannah River Site, Aiken, SC 29802 (May 1990). 
J. R. Zamecnik, 704-T

September 16, 1993

Page 17 of 65

WSRC-TR-93-461

TABLE 1

Material Compositions

\begin{tabular}{|c|c|c|c|c|c|c|c|c|c|c|c|c|c|}
\hline Manufacturer & Material & Ni & $\mathrm{Cr}$ & $\mathrm{Fe}$ & $\mathbf{w}$ & Co & Mo & Mn & Si & $\mathbf{P}$ & $\mathbf{S}$ & C & Other \\
\hline J\&L Speciality & $304 L$ & 8.83 & 18.23 & 69.79 & & 0.10 & 0.24 & 1.79 & 0.61 & 0.030 & 0.018 & 0.026 & $\mathrm{~N} 0.086, \mathrm{Cu} 0.250$ \\
\hline Allegheny-Ludlum & $316 \mathrm{~L}$ & 10.12 & 16.22 & 68.80 & & 0.10 & 2.12 & 1.70 & 0.60 & 0.033 & 0.001 & 0.020 & $\mathrm{~N} 0.040, \mathrm{Cu} 0.250$ \\
\hline Eastern Stainless & $317 L$ & 14.00 & 18.29 & 61.75 & & 0.20 & 3.13 & 1.63 & 0.59 & 0.026 & 0.011 & 0.017 & N $0.072, \mathrm{Cu} 0.280$ \\
\hline Allegheny-Ludlum & AL6XN & 23.92 & 20.67 & 47.80 & & & 6.32 & 0.46 & 0.30 & 0.028 & 0.001 & 0.026 & N $0.230, \mathrm{Cu} 0.250$ \\
\hline Haynes & G-3 & 44.11 & 22.46 & 19.84 & 0.80 & 1.77 & 7.49 & 0.77 & 0.49 & 0.019 & 0.002 & 0.005 & $\mathrm{Cu} 1.880, \mathrm{Cb}+\mathrm{Ta} 0.360$ \\
\hline Duraloy Blaw-Knox & Ma-Re 2* & 48.45 & 32.08 & & 15.72 & & & 0.36 & 0.49 & 0.011 & 0.007 & 0.190 & Al 0.610 \\
\hline Duraloy Blaw-Knox (Cast) & $50 / 50(1657)^{\prime}$ & 50.26 & 47.06 & & & & & 0.15 & 0.36 & 0.020 & 0.002 & 0.010 & $\mathrm{Cb}+\mathrm{Ta} 1.690$ \\
\hline INCO & $671^{*}$ & 53.92 & 45.50 & 0.13 & & & & 0.02 & 0.09 & & 0.003 & 0.050 & $\mathrm{Ti} \quad 0.290$ \\
\hline Haynes & C-22 & 56.00 & 22.00 & 3.00 & 3.00 & 2.50 & 13.00 & 0.50 & 0.08 & & & 0.010 & V 0.350 \\
\hline INCO & $72^{\circ}$ & 56.17 & 43.46 & 0.31 & & & & 0.01 & 0.04 & & & 0.010 & $\mathrm{Cu} 0.010, \mathrm{Ti} 0.610$ \\
\hline Haynes & C-276 & 57.26 & 15.54 & 5.77 & 3.80 & 1.33 & 15.63 & 0.45 & 0.03 & 0.015 & 0.002 & 0.003 & V 0.170 \\
\hline Teledyne-Alivac & Allcorr & 57.99 & 30.93 & 0.11 & & 0.01 & 9.97 & 0.01 & 0.02 & 0.005 & 0.001 & 0.030 & $\begin{array}{c}\text { Al } 0.230, \text { B } 0.002 \\
\mathrm{Zr} 0.010, \mathrm{~V} 0.010, \mathrm{Cb}+\mathrm{Ta} \\
0.420, \mathrm{TI} 0.240 \\
\end{array}$ \\
\hline INCO & $690^{*}$ & 59.40 & 29.10 & 10.48 & & & & 0.42 & 0.30 & & 0.003 & 0.010 & $T I \quad 0.290$ \\
\hline INCO & $625^{*}$ & 60.66 & 21.86 & 4.49 & & & 8.77 & 0.05 & 0.07 & 0.006 & 0.001 & & $\mathrm{Cb}+\mathrm{Ta} 3.570, \mathrm{Tl} 0.260$ \\
\hline Duriron (Cast) & $C W-7 M$ & 61.52 & 18.79 & 1.09 & & & 17.51 & 0.59 & 0.48 & 0.007 & 0.005 & 0.010 & \\
\hline INCO & MA758* & 67.00 & 30.00 & 1.00 & & & & & & & & 0.050 & $\begin{array}{c}\text { Al } 0.300, \text { Ti } 0.500 \\
\text { Y203 } 0.600\end{array}$ \\
\hline Haynes & $556^{*}$ & 22.07 & 21.44 & 31.45 & 2.43 & 17.32 & 3.05 & 1.01 & 0.40 & 0.007 & 0.002 & 0.100 & $\begin{array}{c}\text { Al 0.150, La 0.018, } \\
\text { B } 0.690, \text { Zr } 0.010\end{array}$ \\
\hline Haynes & $8727^{*}$ & 42.49 & 28.76 & 2.31 & 0.10 & 24.35 & 0.05 & 0.38 & 1.50 & 0.005 & 0.001 & 0.057 & \\
\hline Haynes & $188^{\circ}$ & 22.55 & 21.64 & 1.84 & 14.36 & 37.97 & 0.20 & 0.95 & 0.35 & 0.017 & 0.001 & 0.120 & \\
\hline Haynes & 25 & 9.84 & 20.25 & 2.25 & 15.15 & 50.39 & 0.34 & 1.45 & 0.21 & 0.005 & 0.002 & 0.110 & \\
\hline Duraloy Blaw-Knox & Mo-Re 5* & 0.25 & 28.46 & 16.00 & & 53.41 & & 0.87 & 0.84 & 0.020 & 0.030 & 0.120 & \\
\hline Stellite (Cast) & 6 & 3.00 & 30.00 & 3.00 & 5.00 & 54.10 & 1.50 & 1.00 & 1.50 & & & 0.900 & \\
\hline Haynes & $150^{*}$ & 1.37 & 22.42 & 18.94 & & 56.01 & 0.05 & 0.71 & 0.39 & 0.011 & 0.002 & 0.100 & \\
\hline Stellite (Wrought) & $6 \mathrm{~B}$ & 2.25 & 30.02 & 1.74 & 4.13 & 57.45 & 0.97 & 1.68 & 0.65 & 0.013 & 0.001 & 1.100 & \\
\hline Stellite & 6BLC* & 2.73 & 30.35 & 0.10 & 3.98 & 60.35 & 0.10 & 1.70 & 0.58 & 0.011 & 0.004 & 0.100 & \\
\hline
\end{tabular}

- Alloy sample placed in the IDMS Melter

\begin{tabular}{|c|c|c|c|c|c|c|c|c|c|}
\hline Manufacturer & Material & Al2O3 & SiO2 & MgO & Na2O & CaO & Fe2O3 & Cr2O3 & K2O \\
\hline Bolt Technical Ceramics & Alumina & 99.70 & 0.11 & 0.22 & 0.008 & 0.005 & 0.060 & 0.007 & 0.00 \\
\hline
\end{tabular}


J. R. Zamecnik, 704-T

September 16, 1993

Page 18 of 65

WSRC-TR-93-461

TABLE 2

Nominal Cation And Anion

Concentration In sludge-slurry Feed simulants (wt\%, dry)

\begin{tabular}{|c|c|c|c|c|}
\hline Component & Blend (Nd) & Batch 1 & H Modified & Purex \\
\hline \multicolumn{5}{|l|}{ Cation } \\
\hline$\overline{A l}$ & 5.82 & 6.56 & 9.90 & 4.00 \\
\hline $\mathrm{Ba}$ & 0.224 & 0.163 & 0.133 & 0.269 \\
\hline $\mathrm{Ca}$ & 1.89 & 2.16 & 1.35 & 2.19 \\
\hline $\mathrm{Cr}$ & 0.220 & 0.179 & 0.155 & 0.253 \\
\hline $\mathrm{Cu}$ & 0.110 & 0.105 & 0.0445 & 0.132 \\
\hline $\mathrm{Fe}$ & 20.6 & 22.8 & 14.0 & 24.2 \\
\hline $\mathrm{K}$ & 0.298 & 0.248 & 0.130 & 0.258 \\
\hline Mg & 0.183 & 0.156 & 0.213 & 0.134 \\
\hline Mn & 4.97 & 4.68 & 4.89 & 4.72 \\
\hline $\mathrm{Na}$ & 5.56 & 5.68 & 5.97 & 6.47 \\
\hline Nd & 0.433 & 0.249 & 1.04 & 0.0982 \\
\hline $\mathrm{Ni}$ & 1.98 & 1.54 & 0.856 & 2.58 \\
\hline Os & 0.0081 & 0.0046 & 0.0195 & 0.0020 \\
\hline $\mathrm{Pb}$ & 0.255 & 0.278 & 0.156 & 0.312 \\
\hline $\mathbf{S i}$ & 2.98 & 1.44 & 4.60 & 1.04 \\
\hline Sr & 0.101 & 0.060 & 0.250 & 0.020 \\
\hline $\mathrm{Zn}$ & 0.173 & 0.185 & 0.0357 & 0.248 \\
\hline $\mathrm{Zr}$ & 2.17 & 0.768 & 1.41 & 2.57 \\
\hline \multicolumn{5}{|l|}{ Anion } \\
\hline $\mathrm{SO}_{4}$ & 0.650 & 0.665 & 0.494 & 0.735 \\
\hline $\mathrm{PO}_{4}$ & 0.126 & 0.092 & 0.0855 & 0.147 \\
\hline $\mathrm{CO}_{3}$ & 2.26 & 2.92 & 1.15 & 2.88 \\
\hline $\mathrm{NO}_{3}$ & 0.490 & 0.504 & 0.381 & 0.535 \\
\hline $\mathrm{Cl}^{\circ}$ & 0.650 & 0.980 & 0.298 & 0.848 \\
\hline $\mathbf{F}$ & 0.115 & 0.124 & 0.121 & 0.113 \\
\hline I & 0.132 & 0.0184 & 0.000 & 0.0206 \\
\hline $\mathrm{NO}_{2}$ & 7.71 & 7.33 & 8.32 & 7.20 \\
\hline Soluble $\mathrm{OH}$ & 0.634 & 0.738 & 0.654 & 1.46 \\
\hline Organic Carbon & $<0.05$ & $<0.05$ & $<0.05$ & $<0.05$ \\
\hline \multicolumn{5}{|l|}{ Solids Conc. } \\
\hline Total Solids & 15.4 & 15.4 & 15.4 & 15.4 \\
\hline Ins Solids & 13.00 & 12.96 & 12.93 & 12.78 \\
\hline Volume (gal) & 5000 & 5000 & 5000 & 5000 \\
\hline
\end{tabular}


J. R. Zamecnik, 704-T

September 16, 1993

Page 19 of 65

WSRC-TR-93-461

TABLE 3

Final Dimensions of IDMs Coupons

\begin{tabular}{|c|c|c|c|c|c|c|c|}
\hline $\begin{array}{c}\text { IDMS } \\
\text { Rack Location }\end{array}$ & $\begin{array}{l}\text { Coupon } \\
\text { Location }\end{array}$ & $\begin{array}{c}\text { Material } \\
\text { Type }\end{array}$ & $\begin{array}{c}\text { Coupon } \\
\text { No. }\end{array}$ & $\begin{array}{l}\text { Length } \\
\text { (in) }\end{array}$ & $\begin{array}{l}\text { Width } \\
\text { (in) }\end{array}$ & $\begin{array}{l}\text { Hole Dia. } \\
\text { (in) }\end{array}$ & $\begin{array}{c}\text { Thickness } \\
\text { (in) }\end{array}$ \\
\hline SRAT/SME & V & $\mathrm{HC} 22 \mathrm{~W}$ & 1 & 2.005 & 0.750 & 0.391 & 0.115 \\
\hline SRAT/SME & $\mathrm{V}$ & HC276W & 1 & 1.990 & 0.765 & 0.391 & 0.110 \\
\hline SRAT/SME & $\bar{V}$ & $6 \mathrm{~B}$ & 3 & 1.503 & 0.755 & 0.372 & 0.131 \\
\hline SRAT/SME & $\bar{v}$ & ST6 & 1 & 1.609 & 0.859 & 0.370 & 0.233 \\
\hline SRATISME & $\overline{\mathbf{V}}$ & HA25W (s) & 2 & 1.005 & 0.755 & 0.390 & 0.117 \\
\hline SRAT/SME & $\overline{\mathrm{V}}$ & CW7MW & 9 & 2.006 & 0.766 & 0.396 & 0.095 \\
\hline SRAT/SME & V & ALUMINA & 1 & 1.976 & 0.743 & 0.368 & 0.159 \\
\hline SRAT/SME & LN & HC22W & $\overline{2}$ & 2.002 & 0.758 & 0.389 & 0.116 \\
\hline SRATISME & LN & HC276W & 2 & 1.999 & 0.770 & 0.389 & 0.108 \\
\hline SRAT/SME & LN & $6 B$ & 4 & 1.503 & 0.755 & 0.370 & 0.130 \\
\hline SRAT/SME & $\overline{L N}$ & ST6 & 2 & 1.608 & 0.865 & 0.370 & 0.219 \\
\hline SRAT/SME & $\overline{L N}$ & HA25W (s) & 1 & 1.010 & 0.751 & 0.389 & 0.119 \\
\hline SRAT/SME & LN & CW7MW & 2 & 2.019 & 0.745 & 0.390 & 0.098 \\
\hline SRAT/SME & $\overline{L N}$ & ALUMINA & 2 & 1.978 & 0.743 & 0.380 & 0.159 \\
\hline SRAT/SME Condenser & & HG3W (U) & 1 & 3.180 & 0.752 & 0.389 & 0.125 \\
\hline SRAT/SME Condenser & & $316 \mathrm{LW}(U)$ & 1 & 3.175 & 0.750 & 0.389 & 0.112 \\
\hline SRAT/SME Condenser & & AL6XNW (U) & 1 & 3.180 & 0.756 & 0.383 & 0.115 \\
\hline SRAT/SME Condenser & & $317 \mathrm{LW}(\mathrm{U})$ & 1 & 3.125 & 0.757 & 0.389 & 0.095 \\
\hline SRAT/SME Condenser & & $\mathrm{HC} 22 \mathrm{~W}$ & 3 & 2.011 & 0.759 & 0.391 & 0.115 \\
\hline SRAT/SME Condenser & & HC276W & 3 & 1.993 & 0.767 & 0.388 & 0.111 \\
\hline MWWT & & $316 L W$ & 7 & 2.000 & 0.753 & 0.374 & 0.115 \\
\hline MWWT & & $304 \mathrm{LW}$ & 10 & 1.991 & 0.756 & 0.375 & 0.104 \\
\hline MWWT & & AL6X-NW & 5 & 2.001 & 0.761 & 0.388 & 0.108 \\
\hline MWWT & & HC-27бW & 17 & 2.014 & 0.767 & 0.387 & 0.110 \\
\hline MWWT & & $6 B$ & 2 & 1.504 & 0.755 & 0.369 & 0.133 \\
\hline Melter Feed Tank & v & $\mathrm{HC} 22 \mathrm{~W}$ & 5 & 1.999 & 0.758 & 0.389 & 0.119 \\
\hline Melter Feed Tank & $\mathbf{V}$ & HC27бW & 5 & 2.020 & 0.768 & 0.390 & 0.111 \\
\hline Melter Feed Tank & $\bar{V}$ & $6 B$ & 2 & 1.504 & 0.758 & 0.367 & 0.132 \\
\hline Melter Feed Tank & $\mathrm{V}$ & ST6 & 5 & 1.590 & 0.755 & 0.368 & 0.253 \\
\hline Melter Feed Tank & $\mathbf{V}$ & HA25W (s) & 3 & 1.006 & 0.755 & 0.388 & 0.121 \\
\hline Melter Feed Tank & $\mathbf{V}$ & CW7MW & 4 & 2.018 & 0.768 & 0.393 & 0.118 \\
\hline Melter Feed Tank & $\bar{V}$ & ALUMINA & 3 & 1.978 & 0.757 & 0.367 & 0.152 \\
\hline Melter Feed Tank & IN & $\mathrm{HC} 22 \mathrm{~W}$ & 4 & 2.002 & 0.754 & 0.390 & 0.121 \\
\hline Melter Feed Tank & LN & HC276W & 6 & 1.991 & 0.765 & 0.389 & 0.112 \\
\hline Melter Feed Tank & LN & $6 \mathrm{~B}$ & 1 & 1.502 & 0.755 & 0.370 & 0.132 \\
\hline Melter Feed Tank & LN & ST6 & 4 & 1.591 & 0.841 & 0.368 & 0.233 \\
\hline Melter Feed Tank & EN & HA25W (s) & 4 & 1.007 & 0.759 & 0.387 & 0.114 \\
\hline Melter Feed Tank & $\overline{L N}$ & CW7MW & 3 & 2.009 & 0.763 & 0.392 & 0.108 \\
\hline Melter Feed Tank & LN & ALUMINA & 4 & 1.965 & 0.745 & 0.376 & 0.155 \\
\hline Quencher & Inlet & ALLCORRW (s) & 1 & 1.014 & 0.763 & 0.389 & 0.074 \\
\hline Quencher & Inlet & HC276W(s) & 1 & 1.002 & 0.771 & 0.387 & 0.111 \\
\hline Quencher & Inlet & $8727(s)$ & 1 & 1.006 & 0.749 & 0.374 & 0.085 \\
\hline Quencher & Inlet & $\mathrm{HC} 22 \mathrm{~W}(\mathrm{~s})$ & 6 & 2.000 & 0.756 & 0.388 & 0.119 \\
\hline Quencher & Inlet & $1671(\mathrm{~s})$ & 1 & 1.030 & 0.750 & 0.375 & 0.120 \\
\hline Quencher & Inlet & $1690 \mathrm{~W}(\mathrm{~s})$ & 1 & 1.003 & 0.750 & 0.387 & 0.119 \\
\hline Quencher & Inlet & HA556 (s) & 1 & 1.006 & 0.758 & 0.390 & 0.118 \\
\hline Quencher & Inlet & $6 B L C(s)$ & 1 & 1.034 & 0.744 & 0.370 & 0.085 \\
\hline Quencher & Inlet & $1625 \mathrm{~W}(\mathrm{~s})$ & 1 & 1.009 & 0.765 & 0.389 & 0.115 \\
\hline Quencher & Inlet & CW7MW (s) & 1 & 0.997 & 0.760 & 0.390 & 0.117 \\
\hline
\end{tabular}

$V=$ Vapor Zone

$\mathrm{L}=$ Liquid Zone

$L N=$ Liquid/Napor Zone
$W=$ Welded Coupon

$(U)=U-B e n d$ Specimen

$(s)=$ Small Flat Coupon 
J. R. Zamecnik, 704-T

September 16, 1993

Page 20 of 65

WSRC-TR-93-461

TABLE 3 (Cont.)

Final Dimensions of IDMs Coupons

\begin{tabular}{|c|c|c|c|c|c|c|c|}
\hline $\begin{array}{c}\text { IDMS } \\
\text { Rack Location }\end{array}$ & $\begin{array}{l}\text { Coupon } \\
\text { Location }\end{array}$ & $\begin{array}{c}\text { Material } \\
\text { Type }\end{array}$ & $\begin{array}{c}\text { Coupon } \\
\text { No. }\end{array}$ & $\begin{array}{l}\text { Length } \\
\text { (in) }\end{array}$ & $\begin{array}{l}\text { Width } \\
\text { (in) }\end{array}$ & $\begin{array}{l}\text { Hole Dia. } \\
\text { (in) }\end{array}$ & $\begin{array}{c}\text { Thickness } \\
\text { (in) }\end{array}$ \\
\hline Quencher & Outlet & ALLCORRW & 1 & 1.999 & 0.767 & 0.389 & 0.095 \\
\hline Quencher & Outlet & HC276W & 7 & 1.979 & 0.764 & 0.389 & 0.111 \\
\hline Quencher & Outlet & HC276W & 8 & 1.998 & 0.760 & 0.389 & 0.111 \\
\hline Quencher & Outlet & $\mathrm{HC} 22 \mathrm{~W}$ & 7 & 2.000 & 0.755 & 0.389 & 0.117 \\
\hline Quencher & Outlet & $\mathrm{HC} 22 \mathrm{~W}$ & 8 & 2.000 & 0.755 & 0.392 & 0.117 \\
\hline Quencher & Outlel & CW7MW & 5 & 2.013 & 0.768 & $\frac{0.393}{0.394}$ & $\frac{0.113}{0.102}$ \\
\hline Quencher & Outlet & CW7MW & 6 & 2.016 & 0.768 & 0.394 & 0.102 \\
\hline SAS & & ST6 & 6 & 1.647 & 0.804 & 0.370 & 0.230 \\
\hline SAS & & ALLCORRW & 3 & 1.997 & 0.767 & 0.389 & 0.098 \\
\hline SAS & & $6 \mathrm{~B}$ & 7 & 1.502 & 0.756 & 0.370 & 0.131 \\
\hline SAS & & $\mathrm{HC} 22 \mathrm{~W}$ & 14 & 2.000 & 0.758 & 0.391 & 0.115 \\
\hline SAS & & HC276W & 13 & 1.996 & 0.764 & 0.390 & 0.113 \\
\hline Off-Gas Condenser & Drain & $\mathrm{HC} 276 \mathrm{~W}$ & 10 & 1.999 & 0.760 & 0.389 & 0.110 \\
\hline Off-Gas Condenser & Drain & $317 L W(U)$ & 3 & 3.125 & 0.763 & 0.390 & 0.091 \\
\hline Off-Gas Condenser & Drain & $\mathrm{HC} 22 \mathrm{~W}$ & 10 & 1.999 & 0.760 & 0.391 & 0.121 \\
\hline Off-Gas Condenser & Drain & AL6XNW U) & 3 & 3.165 & 0.756 & 0.389 & 0.117 \\
\hline OGCT & v & $\mathrm{HC} 22 \mathrm{~W}$ & 13 & 1.999 & 0.759 & 0.389 & 0.115 \\
\hline OGCT & V & $\mathrm{HC} 276 \mathrm{~W}$ & 11 & 1.998 & 0.766 & 0.390 & 0.108 \\
\hline OGCT & $\bar{V}$ & CW7MW & 7 & 2.006 & 0.768 & 0.392 & 0.098 \\
\hline OGCT & $\bar{V}$ & ST6 & 7 & 1.602 & 0.834 & 0.369 & 0.230 \\
\hline OGCT & $\overline{\mathbf{V}}$ & HA25W (s) & 5 & 0.999 & 0.756 & 0.389 & 0.122 \\
\hline OGCT & $\bar{v}$ & $6 \mathrm{~B}$ & 6 & 1.497 & 0.754 & 0.371 & 0.132 \\
\hline OGCT & $\tau$ & HC22WV & 12 & 1.992 & 0.753 & 0.388 & 0.118 \\
\hline OGCT & $\bar{L}$ & HC276W & 12 & 1.999 & 0.759 & 0.390 & 0.112 \\
\hline OGCT & $\bar{L}$ & CW7MW & 8 & 2.014 & 0.762 & 0.397 & 0.099 \\
\hline OGCT & L & ST6 & 8 & 1.620 & 0.838 & 0.368 & 0.220 \\
\hline HEME & Outlet & $316 \mathrm{LW}$ & 8 & 1.998 & 0.745 & 0.375 & 0.112 \\
\hline HEME & Outlet & $304 \mathrm{LW}$ & 9 & 1.995 & 0.755 & 0.375 & 0.111 \\
\hline HEPA & Inlet & $317 \mathrm{LW}$ & 2 & 2.006 & 0.760 & 0.391 & 0.106 \\
\hline HEPA & Inlet & AL6XNW & 3 & 2.002 & 0.761 & 0.389 & 0.109 \\
\hline HEPA & Inlet & $316 L W$ & 3 & 1.996 & 0.770 & 0.387 & 0.098 \\
\hline HEPA & Inlet & $304 \mathrm{LW}$ & $\overline{3}$ & 1.997 & 0.769 & 0.390 & 0.092 \\
\hline
\end{tabular}

$V=$ Vapor Zone

$L=$ Liquid Zone

LN = Liquid/Napor Zone
$W=$ Welded Coupon

$(U)=U$-Bend Specimen

(s) = Small Flat Coupon 
J. R. Zamecnik, 704-T

September 16,1993

Page 21 of 65

WSRC-TR-93-461

TABLE 4

\section{Final Weights And Weight Change Calculation For IDMs Coupons}

\begin{tabular}{|c|c|c|c|c|c|c|}
\hline $\begin{array}{c}\text { IDMS } \\
\text { Rack Location }\end{array}$ & $\begin{array}{l}\text { Coupon } \\
\text { Location }\end{array}$ & $\begin{array}{c}\text { Material } \\
\text { Type }\end{array}$ & $\begin{array}{c}\text { Coupon } \\
\text { No. }\end{array}$ & $\begin{array}{c}\text { Initial Weight" } \\
\text { (g) }\end{array}$ & $\begin{array}{c}\text { Final Weight } \\
\text { (g) }\end{array}$ & $\begin{array}{c}\text { Weight Change } \\
\text { (g) }\end{array}$ \\
\hline SRAT/SME & $v$ & $\mathrm{HC} 22 \mathrm{~W}$ & 1 & 22.1693 & 22.1717 & 0.0024 \\
\hline SRAT/SME & $\bar{v}$ & $\mathrm{HC} 276 \mathrm{~W}$ & 1 & 22.0781 & 22.0795 & 0.0014 \\
\hline SRAT/SME & V & $6 \mathrm{~B}$ & 3 & 18.1085 & 18.1069 & -0.0016 \\
\hline SRAT/SME & V & ST6 & 1 & 40.3343 & 40.3303 & -0.0040 \\
\hline SRAT/SME & $\bar{V}$ & HA25W (s) & 2 & 11.1865 & 11.1868 & 0.0003 \\
\hline SRAT/SME & $\bar{v}$ & CW7MW & 1 & 18.4065 & 18.4044 & -0.0021 \\
\hline SRAT/SME & $\bar{v}$ & ALUMINA & 1 & 13.3970 & 13.3962 & -0.0008 \\
\hline SRAT/SME & LV & $\mathrm{HC} 22 \mathrm{~W}$ & 2 & 22.8065 & 22.8062 & -0.0003 \\
\hline SRATISME & $\overline{L N}$ & HC275W & 2 & 22.0029 & 22.0028 & -0.0001 \\
\hline SRATISME & LN & $6 \mathrm{~B}$ & 4 & 18.2035 & 18.2020 & -0.0015 \\
\hline SRAT/SME & LN & ST6 & 2 & 38.5938 & 38.5812 & -0.0126 \\
\hline SRATISME & $\overline{L N}$ & HA25W (s) & 1 & 11.2009 & 11.2011 & 0.0002 \\
\hline SRATISME & LN & CW7MW & 2 & 19.4842 & 19.4817 & -0.0025 \\
\hline SRAT/SME & LN & ALUMINA & 2 & 13.3328 & 13.3346 & 0.0018 \\
\hline SRAT/SME Condenser & & HG $3 W(U)$ & 1 & 32.0015 & 32.0192 & 0.0177 \\
\hline SRAT/SME Condenser & & $316 \mathrm{LW}(U)$ & $\frac{1}{1}$ & 28.6703 & 28.6883 & 0.0180 \\
\hline SRAT/SME Condenser & & AL6XNW U) & 1 & 30.4406 & 30.4521 & 0.0115 \\
\hline SRAT/SME Condenser & & $317 L W(U)$ & 1 & 24.4498 & 24.4628 & 0.0130 \\
\hline SRAT/SME Condenser & & $\mathrm{HC} 22 \mathrm{~W}$ & 3 & 23.0813 & 23.0861 & 0.0048 \\
\hline SRAT/SME Condenser & & HC276W & 3 & 22.1704 & 22.1697 & -0.0007 \\
\hline MWWT & & $316 L W$ & 7 & 20.1692 & 20.1685 & -0.0007 \\
\hline MWWT & & $304 \mathrm{LW}$ & 10 & 19.4694 & 19.4685 & -0.0009 \\
\hline MWWT & & AL6X-NW & 5 & 20.4082 & 20.4087 & 0.0005 \\
\hline MWWT & & HC-276W & 17 & 22.3438 & 22.3440 & 0.0002 \\
\hline MWWT & & $6 B$ & 2 & 18.5337 & 18.5336 & -0.0001 \\
\hline Melter Feed Tank & v & $\mathrm{HC} 22 \mathrm{~W}$ & 5 & 22.5704 & 22.5718 & 0.0014 \\
\hline Melter Feed Tank & $\overline{\mathrm{V}}$ & HC276W & 5 & 21.6912 & 21.6925 & 0.0013 \\
\hline Melter Feed Tank & $\bar{V}$ & $6 \mathrm{~B}$ & 2 & 18.2622 & 18.2627 & 0.0005 \\
\hline Melter Feed Tank & v & ST6 & 5 & 37.1386 & 37.1413 & 0.0027 \\
\hline Melter Feed Tank & $\mathrm{V}$ & HA25W (s) & 3 & 11.3039 & 11.3047 & 0.0008 \\
\hline Melter Feed Tank & $\bar{V}$ & CW7MW & 4 & 22.7386 & 22.7395 & 0.0009 \\
\hline Melter Feed Tank & V & ALUMINA & 3 & 13.0519 & 13.0510 & -0.0009 \\
\hline Melter Feed Tank & $\overline{L N}$ & HC22W & 4 & 22.7645 & 22.7681 & 0.0036 \\
\hline Melter Feed Tank & LN & HC276W & 6 & 21.6486 & 21.6528 & 0.0042 \\
\hline Melter Feed Tank & LN & $6 B$ & $\frac{\pi}{1}$ & 18.2145 & 18.2144 & -0.0001 \\
\hline Melter Feed Tank & LN & ST6 & 4 & 38.5446 & 38.5484 & 0.0038 \\
\hline Melter Feed Tank & $\overline{L N}$ & HA25W (s) & 4 & 10.6580 & 10.6590 & 0.0010 \\
\hline Melter Feed Tank & LN & CW7MW & 3 & 20.1882 & 20.1910 & 0.0028 \\
\hline Melter Feed Tank & LN & ALUMINA & 4 & 13.0477 & 13.0534 & 0.0057 \\
\hline Quencher & Inlet & HA556 (s) & 1 & 9.8420 & 9.8142 & -0.0278 \\
\hline Quencher & Inlet & $1625 \mathrm{~W}(\mathrm{~s})$ & 1 & 9.8718 & 9.8381 & -0.0337 \\
\hline Quencher & Inlet & CW7MW (s) & $\frac{1}{1}$ & 9.7851 & 9.7410 & -0.0441 \\
\hline Quencher & Inlet & $\mathrm{HC} 22 \mathrm{~W}(\mathrm{~s})$ & 6 & 22.5802 & 22.3109 & -0.2693 \\
\hline Quencher & Inlet & $1671(\mathrm{~s})$ & 1 & 9.9768 & 9.8179 & -0.1589 \\
\hline Quencher & Inlet & $1690 \mathrm{~W}(\mathrm{~s})$ & 1 & 9.4146 & 9.2497 & -0.1649 \\
\hline Quencher & Inlet & ALLCORRW (s) & 1 & 6.3369 & 6.2233 & -0.1136 \\
\hline Quencher & Inlet & $\mathrm{HC} 276 \mathrm{~W}(\mathrm{~s})$ & 1 & 9.6959 & 9.5026 & -0.1933 \\
\hline Quencher & Inlet & $6 B L C(s)$ & 1 & 7.5153 & 7.3413 & -0.1740 \\
\hline Quencher & Inlet & $8727(\mathrm{~s})$ & 1 & 7.0436 & 6.8187 & -0.2249 \\
\hline
\end{tabular}

- See Reference 2

$V=$ Vapor Zone

$L=$ Liquid Zone

LN = Liquid/Napor Zone
$W=$ Welded Coupon

$(U)=U$-Bend Specimen

(s) = Small Flat Coupon 
J. R. Zamecnik, 704-T

September 16, 1993

Page 22 of 65

WSRC-TR-93-461

TABLE 4 (cont.)

Final Weights And weight Change calculation For IDMs Coupons

\begin{tabular}{|c|c|c|c|c|c|c|}
\hline $\begin{array}{c}\text { IDMS } \\
\text { Rack Location } \\
\end{array}$ & $\begin{array}{l}\text { Coupon } \\
\text { Location }\end{array}$ & $\begin{array}{c}\text { Material } \\
\text { Type }\end{array}$ & $\begin{array}{c}\text { Coupon } \\
\text { No. }\end{array}$ & $\begin{array}{c}\text { Initial Weight" } \\
\text { (g) }\end{array}$ & $\begin{array}{c}\text { Final Weight } \\
(\mathrm{g})\end{array}$ & $\begin{array}{c}\text { Weight Change } \\
\text { (g) }\end{array}$ \\
\hline Quencher & Outlet & ALLCORRW & 1 & 17.4982 & 17.5019 & 0.0037 \\
\hline Quencher & Outlet & ALLCORRW & 2 & 15.7689 & 15.7718 & 0.0029 \\
\hline Quencher & Outlet & $\mathrm{HC} 276 \mathrm{~W}$ & $\overline{7}$ & 21.5529 & 21.5482 & $-0,0047$ \\
\hline Quencher & Outlet & HC276W & 8 & 21.4353 & 21.4303 & -0.0050 \\
\hline Quencher & Outlet & $\mathrm{HC} 22 \mathrm{~W}$ & 7 & 21.5448 & 21.5975 & 0.0527 \\
\hline Quencher & Outlet & $\mathrm{HC} 22 \mathrm{~W}$ & 8 & 22.1526 & 22.1556 & 0.0030 \\
\hline Quencher & Outlet & $1625 W$ & 1 & 20.9760 & 20.9793 & 0.0033 \\
\hline Quencher & Outlet & $1625 \mathrm{~W}$ & 2 & 21.6140 & 21.6179 & 0.0039 \\
\hline Quencher & Outlet & CW7MW & 5 & 21.4257 & 21.4186 & -0.0071 \\
\hline Quencher & Outlet & CW7MW & 6 & 19.1589 & 19.1467 & -0.0122 \\
\hline OGCT & $\mathrm{v}$ & $\mathrm{HC} 22 \mathrm{~W}$ & 13 & 22.0451 & 22.0470 & 0.0019 \\
\hline OGCT & V & HC276W & 11 & 21.1929 & 21.1917 & -0.0012 \\
\hline OGCT & v & CW7MW & 7 & 18.0509 & 18.0449 & -0.0060 \\
\hline OGCT & $\bar{v}$ & ST6 & 7 & 37.6655 & 37.6682 & 0.0027 \\
\hline OGCT & V & HA25W (s) & 5 & No Initial Data & 11.1645 & No Initial Data \\
\hline OGCT & V & $6 \mathrm{~B}$ & 6 & 18.0946 & 18.0906 & -0.0040 \\
\hline OGCT & $\mathrm{L}$ & $\mathrm{HC} 22 \mathrm{~W}$ & 12 & 21.7607 & 21.7627 & 0.0020 \\
\hline OGCT & $L$ & $\mathrm{HC276W}$ & 12 & 21.3489 & 21.3496 & 0.0007 \\
\hline OGCT & $L$ & CW7MW & 8 & 17.9248 & 17.9223 & -0.0025 \\
\hline OGCT & $\bar{L}$ & ST6 & 8 & 37.3585 & 37.3593 & 0.0008 \\
\hline OGCT & $\mathrm{L}$ & HA25W & 6 & No Initial Data & 25.0116 & NoInitial Data \\
\hline OGCT & $L$ & $6 B$ & 5 & 18.0749 & 18.0765 & 0.0016 \\
\hline Off-Gas Condenser & Inlet & HC276W & 9 & 21.6785 & 21.6776 & -0.0009 \\
\hline Off-Gas Condenser & Inlet & $317 \mathrm{LW}(\mathrm{U})$ & 2 & 24.0720 & 24.0659 & -0.0061 \\
\hline Off-Gas Condenser & Inlet & $\mathrm{HC} 22 \mathrm{~W}$ & 9 & 22.4036 & 22.4050 & 0.0014 \\
\hline Off-Gas Condenser & Inlet & AL.6XNW (U) & 2 & 30.2956 & 30.2965 & 0.0009 \\
\hline Off-Gas Condenser & Drain & $\mathrm{HC} 276 \mathrm{~W}$ & 10 & 21.7680 & 21.7696 & 0.0016 \\
\hline Off-Gas Condenser & Drain & $317 \mathrm{LW}(U)$ & 3 & 23.2278 & 23.2285 & 0.0007 \\
\hline Off-Gas Condenser & Drain & $\mathrm{HC} 22 \mathrm{~W}$ & 10 & 22.7220 & 22.7240 & 0.0020 \\
\hline Off-Gas Condenser & Drain & $A L 6 X N W(U)$ & 3 & 30.6502 & 30.6520 & 0.0018 \\
\hline SAS & & ST6 & 6 & 38.0081 & 38.0099 & 0.0018 \\
\hline SAS & & ALLCORRW & 3 & 17.8572 & 17.8586 & 0.0014 \\
\hline SAS & & $6 \mathrm{~B}$ & 7 & 18.1119 & 18.1121 & 0.0002 \\
\hline SAS & & $\mathrm{HC} 22 \mathrm{~W}$ & 14 & 21.7792 & 21.7808 & 0.0016 \\
\hline SAS & & HC276W & 13 & 21.8224 & 21.8230 & 0.0006 \\
\hline HEME & Inlet & AL6XNW & 4 & $30.9693^{\circ}$ & 19.3848 & Initial Data Incorrect \\
\hline HEME & Inlet & HC276W & 14 & 22.0572 & 22.0559 & -0.0013 \\
\hline HEME & Inlet & $316 L W(U)$ & 2 & 28.6703 & 28.6616 & -0.0087 \\
\hline HEME & Inlet & $304 L W(U)$ & 1 & 28.9064 & 28.8586 & -0.0478 \\
\hline HEME & Outlet & $317 L W$ & 1 & 18.3992 & 18.3998 & 0.0006 \\
\hline HEME & Outlet & ALGXNW & 2 & 20.3229 & 20.3248 & 0.0019 \\
\hline HEME & Outlet & $316 L \mathrm{~W}$ & 8 & 19.2118 & 19.2061 & -0.0057 \\
\hline HEME & Outlel & $304 \mathrm{LW}$ & 9 & 19.5396 & 19.5309 & -0.0087 \\
\hline HEPA & Inlet & $317 L W$ & 2 & 18.7209 & 18.7222 & 0.0013 \\
\hline HEPA & Inlet & AL6XNW & 3 & 19.6882 & 19.6901 & 0.0019 \\
\hline HEPA & Inlet & $316 \mathrm{LW}$ & 3 & 18.9071 & 18.9063 & -0.0008 \\
\hline HEPA & Inlet & $304 L W$ & 3 & 16.2592 & 16.2592 & 0.0000 \\
\hline
\end{tabular}

- See Reference 2

$V=$ Vapor Zone

$L=$ Liquid Zone

LN = Liquid/Napor Zone
$W=$ Welded Coupon

$(U)=U$-Bend Specimen

(s) = Small Flat Coupon 
J. R. Zamecnik, 704-T

September 16, 1993

Page 23 of 65

WSRC-TR-93-461

TABLE 5

Results of Examination of Quencher Inlet Corrosion Coupons

\begin{tabular}{|c|c|c|c|c|c|c|}
\hline $\begin{array}{l}\text { Corrosion } \\
\text { Coupon }\end{array}$ & $\begin{array}{c}\text { Machining } \\
\text { Marks }\end{array}$ & $\begin{array}{c}\text { End Grain } \\
\text { Attack }\end{array}$ & $\begin{array}{c}\text { Pitting } \\
\text { Corrosion }\end{array}$ & $\begin{array}{l}\text { Crevice } \\
\text { Corrosion }\end{array}$ & $\begin{array}{c}\text { General } \\
\text { Non-Uniform }\end{array}$ & $\begin{array}{c}\text { Weight Loss } \\
(\%)\end{array}$ \\
\hline $\begin{array}{l}\text { Hastelloy } \\
\text { C-22 }\end{array}$ & $\begin{array}{l}\text { Gone Outside Washer, } \\
\text { Present under washer }\end{array}$ & 1 & 1 & 2 & 3 & 1.19 \\
\hline $\begin{array}{l}\text { Inconel } \\
625\end{array}$ & $\begin{array}{l}\text { Still visible under and } \\
\text { outside washer }\end{array}$ & 1 & 2 & 1 & 2 & 0.34 \\
\hline $\begin{array}{l}\text { Duriron } \\
\text { CW7M }\end{array}$ & $\begin{array}{l}\text { Still visible under and } \\
\text { outside washer }\end{array}$ & 1 & 2 & 1 & 1 & 0.45 \\
\hline $\begin{array}{l}\text { Hastelloy } \\
\text { C-276** }\end{array}$ & $\begin{array}{l}\text { Present under washer } \\
\text { Gone outside washer }\end{array}$ & 2 & 2 & 1 & 4 & 1.99 \\
\hline $\begin{array}{l}\text { Haynes } \\
8727\end{array}$ & $\begin{array}{l}\text { Marks are still somewhat } \\
\text { visible. Material is hard so } \\
\text { marks were not very deep } \\
\text { originally. }\end{array}$ & 2 & 2 & 1 & 3 & 3.19 \\
\hline $\begin{array}{l}\text { Inconel } \\
671\end{array}$ & $\begin{array}{l}\text { Gone outside washer } \\
\text { Present under washer }\end{array}$ & 4 & 3 & 1 & 1 & 1.59 \\
\hline $\begin{array}{l}\text { Inconel } \\
690 \cdots *\end{array}$ & Most are gone & 4 & 3 & 1 & 3 & 1.75 \\
\hline $\begin{array}{c}\text { Haynes } \\
556\end{array}$ & $\begin{array}{l}\text { Slightly visible under } \\
\text { washer }\end{array}$ & 1 & 3 & 3 & 2 & 0.28 \\
\hline $\begin{array}{l}\text { Teledyne-Allvac } \\
\text { Allcorr* }\end{array}$ & $\begin{array}{l}\text { Slightly visible under } \\
\text { washer } \\
\text { Gone outside washer }\end{array}$ & 3 & 3 & 3 & 2 & 1.79 \\
\hline $\begin{array}{l}\text { Stellite } \\
\text { 6BLC }\end{array}$ & $\begin{array}{l}\text { Slightly visible under } \\
\text { washer } \\
\text { Most gone outside washer }\end{array}$ & 1 & 4 & 4 & 4 & 2.32 \\
\hline
\end{tabular}

- Material of construction for DWPF primary Quencher.

-* Material of construction for DWPF backup Quencher and IDMS Quencher.

..* Material of construction for DWPF and IDMS Off-Gas Film Cooler.

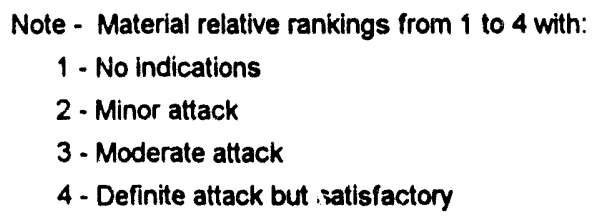


J. R. Zamecnik, 704-T

September 16, 1993

Page 24 of 65

WSRC-TR-93-461

TABLE 6

Pit Dimensions of Quencher Inlet corrosion Coupons

\begin{tabular}{|c|c|c|c|c|}
\hline Alloy & Coupon & $\begin{array}{l}\text { Pit Depth } \\
\text { (in) }\end{array}$ & $\begin{array}{l}\text { Length } \\
\text { (in) }\end{array}$ & $\begin{array}{l}\text { width } \\
\text { (in) }\end{array}$ \\
\hline $\begin{array}{c}\text { Teledyne-Allvac } \\
\text { Allcorr }\end{array}$ & $\begin{array}{l}\text { ALLCORRW } \\
\text { (1) }\end{array}$ & $\begin{array}{l}0.0026 \\
0.0022\end{array}$ & $\begin{array}{l}0.0190 \\
0.0182\end{array}$ & $\begin{array}{l}0.0215 \\
0.0200\end{array}$ \\
\hline $\begin{array}{l}\text { Hastelloy } \\
\quad \mathrm{C}-276\end{array}$ & $\begin{array}{l}\mathrm{HC} 276 \mathrm{~W} \\
(1)\end{array}$ & $\begin{array}{l}0.0012 \\
0.0023\end{array}$ & $\begin{array}{l}0.0137 \\
0.0116\end{array}$ & $\begin{array}{l}0.0113 \\
0.0194\end{array}$ \\
\hline $\begin{array}{c}\text { Hastelloy } \\
\text { C-22 }\end{array}$ & $\begin{array}{l}\mathrm{HC} 22 \mathrm{~W} \\
(6)\end{array}$ & $\begin{array}{l}0.0010 \\
0.0017\end{array}$ & $\begin{array}{l}0.0046 \\
0.0050\end{array}$ & $\begin{array}{l}0.0100 \\
0.0062\end{array}$ \\
\hline $\begin{array}{l}\text { Inconel } \\
690\end{array}$ & $\begin{array}{l}\text { I690W } \\
\text { (1) }\end{array}$ & $\begin{array}{l}0.0012 \\
0.0040\end{array}$ & $\begin{array}{l}0.0101 \\
0.0076\end{array}$ & $\begin{array}{l}0.0305 \\
0.0339\end{array}$ \\
\hline $\begin{array}{l}\text { Inconel } \\
671\end{array}$ & $\begin{array}{c}1671 \\
(1)\end{array}$ & $\begin{array}{l}0.0014 \\
0.0027\end{array}$ & $\begin{array}{l}0.0126 \\
0.0177\end{array}$ & $\begin{array}{l}0.0116 \\
0.0150\end{array}$ \\
\hline $\begin{array}{l}\text { Inconel } \\
\quad 6 ? 5\end{array}$ & $\begin{array}{l}\text { I625W } \\
\text { (1) }\end{array}$ & $\begin{array}{l}0.0011 \\
0.0033\end{array}$ & $\begin{array}{l}0.0365 \\
0.0084\end{array}$ & $\begin{array}{l}0.0398 \\
0.0388\end{array}$ \\
\hline $\begin{array}{l}\text { Haynes } \\
556\end{array}$ & $\begin{array}{l}\text { HA556 } \\
\text { (1) }\end{array}$ & $\begin{array}{l}0.0028 \\
0.0076\end{array}$ & $\begin{array}{l}0.1287 \\
0.0961\end{array}$ & $\begin{array}{l}0.0671 \\
0.1911\end{array}$ \\
\hline $\begin{array}{l}\text { Haynes } \\
8727\end{array}$ & $\begin{array}{c}8727 \\
(1)\end{array}$ & $\begin{array}{l}0.0013 \\
0.0025\end{array}$ & $\begin{array}{l}0.0074 \\
0.0157\end{array}$ & $\begin{array}{l}0.0085 \\
0.0185\end{array}$ \\
\hline $\begin{array}{l}\text { Stellite } \\
\text { 6BLC }\end{array}$ & $\begin{array}{c}\text { 6BLC } \\
(1)\end{array}$ & $\begin{array}{l}0.0022 \\
0.0036\end{array}$ & $\begin{array}{l}0.0602 \\
0.0138\end{array}$ & $\begin{array}{l}0.3127 \\
0.0321\end{array}$ \\
\hline $\begin{array}{l}\text { Duriron } \\
\text { CW7M }\end{array}$ & $\begin{array}{l}\text { CW7MW } \\
\text { (1) }\end{array}$ & $\begin{array}{l}0.0024 \\
0.0025\end{array}$ & $\begin{array}{l}0.0081 \\
0.0124\end{array}$ & $\begin{array}{l}0.0087 \\
0.0122\end{array}$ \\
\hline
\end{tabular}


J. R. Zamecnik, 704-T

September 16,1993

Page 25 of 65

WSRC-TR-93-461

TABLE 7

Pit Dimensions on $317 \mathrm{LW}$ (1) U-Bend specimen From off Gas Condenser vapor Inlet

\begin{tabular}{|c|c|c|}
\hline $\begin{array}{c}\text { Pit Depth } \\
\text { (in) }\end{array}$ & $\begin{array}{c}\text { Length } \\
\text { (in) }\end{array}$ & $\begin{array}{c}\text { width } \\
\text { (in) }\end{array}$ \\
\hline 0.0017 & 0.2176 & 0.0435 \\
\hline 0.0020 & 0.0857 & 0.0580 \\
\hline 0.0046 & 0.1363 & 0.0845 \\
\hline
\end{tabular}

TABLE 8

Pit Dimensions on $316 \mathrm{LW}$ (2) and $304 \mathrm{LW}$ (1) U-Bend specimens From HEME Inlet

\begin{tabular}{|c|c|c|c|c|c|c|}
\hline \multicolumn{3}{|c|}{$304 \mathrm{LW}(1)$} & & \multicolumn{3}{|c|}{$316 \mathrm{LW}$ (2) } \\
\hline $\begin{array}{c}\text { Pit Depth } \\
\text { (in) }\end{array}$ & $\begin{array}{c}\text { Length } \\
\text { (in) }\end{array}$ & $\begin{array}{c}\text { Width } \\
\text { (in) }\end{array}$ & & $\begin{array}{c}\text { Pit Depth } \\
(\text { in) }\end{array}$ & $\begin{array}{c}\text { Length } \\
\text { (in) }\end{array}$ & $\begin{array}{c}\text { Width } \\
\text { (in) }\end{array}$ \\
\hline 0.0122 & 0.1265 & 0.0354 & & 0.0058 & 0.0652 & 0.0478 \\
\hline 0.0029 & 0.1997 & 0.1010 & & 0.0022 & 0.1865 & 0.0820 \\
\hline
\end{tabular}


J. R. Zamecnik, 704-T

September 16, 1993

Page 26 of 65

WSRC-TR-93-461

FIGURE 1

\section{Bchematic of IDMs showing Locations of Corrosion Coupons And The Materials of Construction of The various Process Vessels}

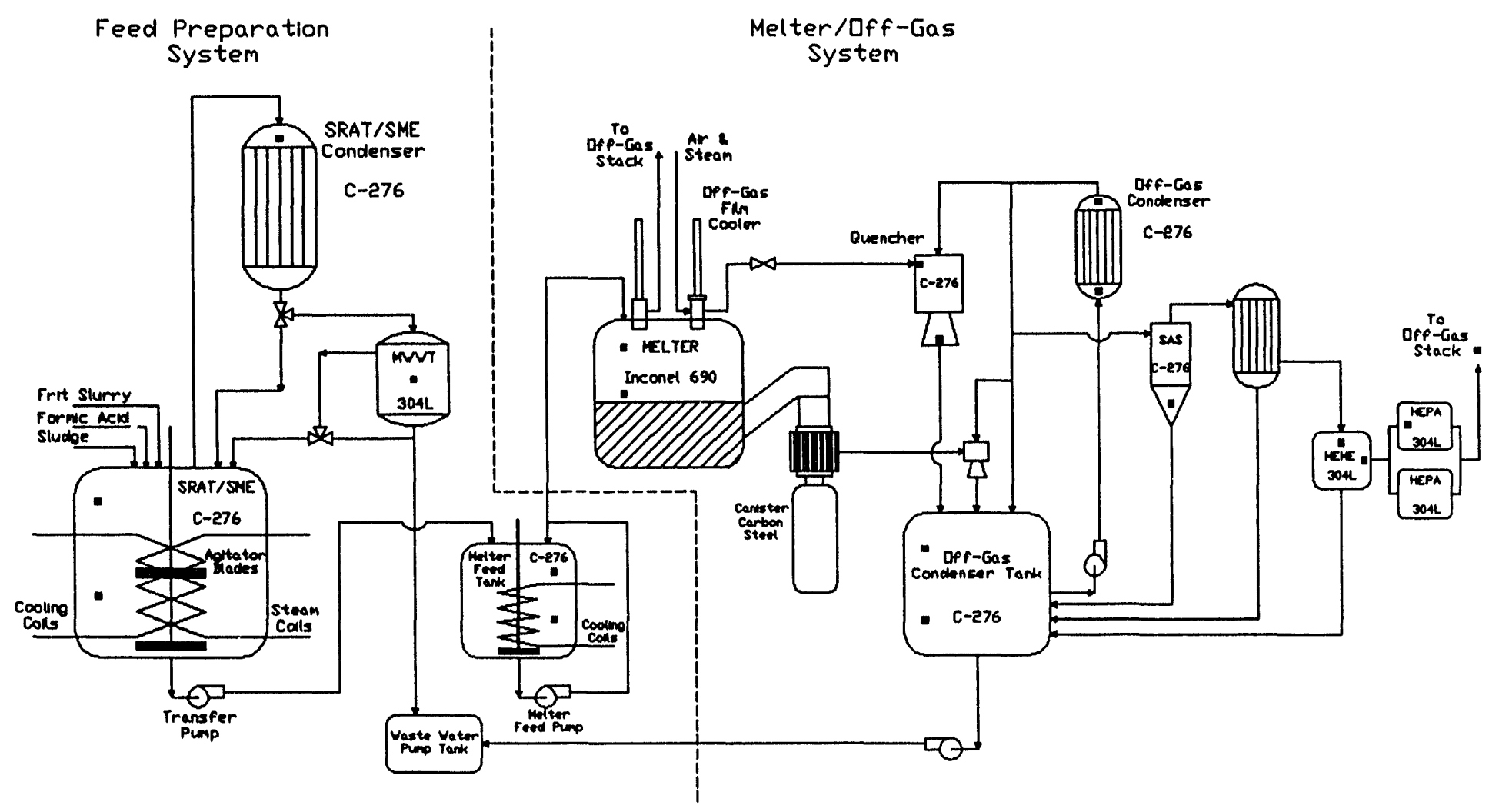

- Corrosion Racik Location 
J. R. Zame cnik, 704-T

September 16, 1993

Page 27 of 65

WSRC-TR-93-461

\section{FIGURE 2}

BRAT/SME Vapor space Corrosion Coupon Rack

Photograph Prior To Cleaning (Negative No. EE52534-A) and schematic showing Location of Coupons on Rack

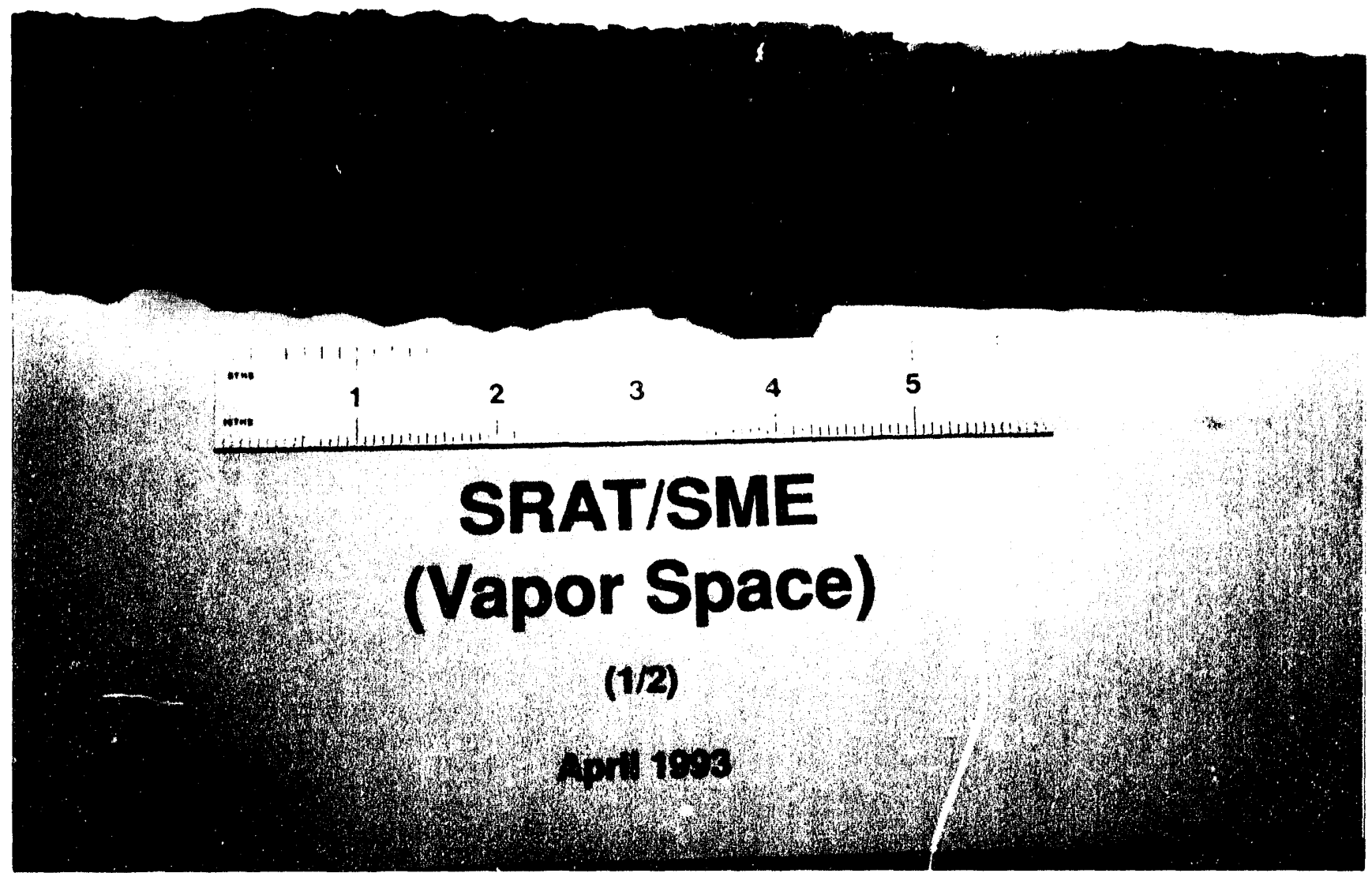

VAPQR

(TDP)
LIQUID/VAPOR (BDTTDM)

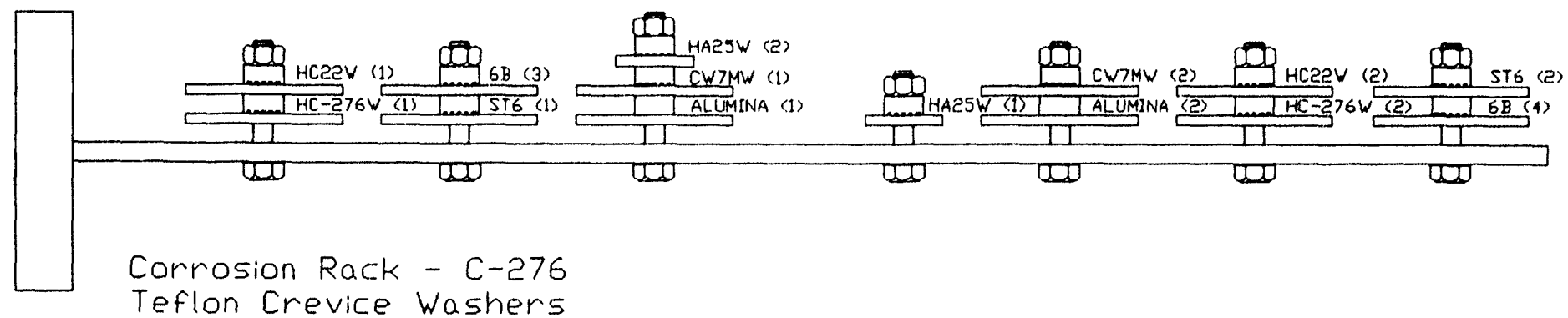


J. R. Zamecnik, 704-T

September 16,1993

Page 28 of 65

WSRC-TR-93-461

FIGURE 3

SRAT/8ME Liquid/Vapor zone Corrosion Coupon Rack

Photograph Prior To Cleaning (Negative No. EE52534-A) and schematic showing Location of Coupons on Rack

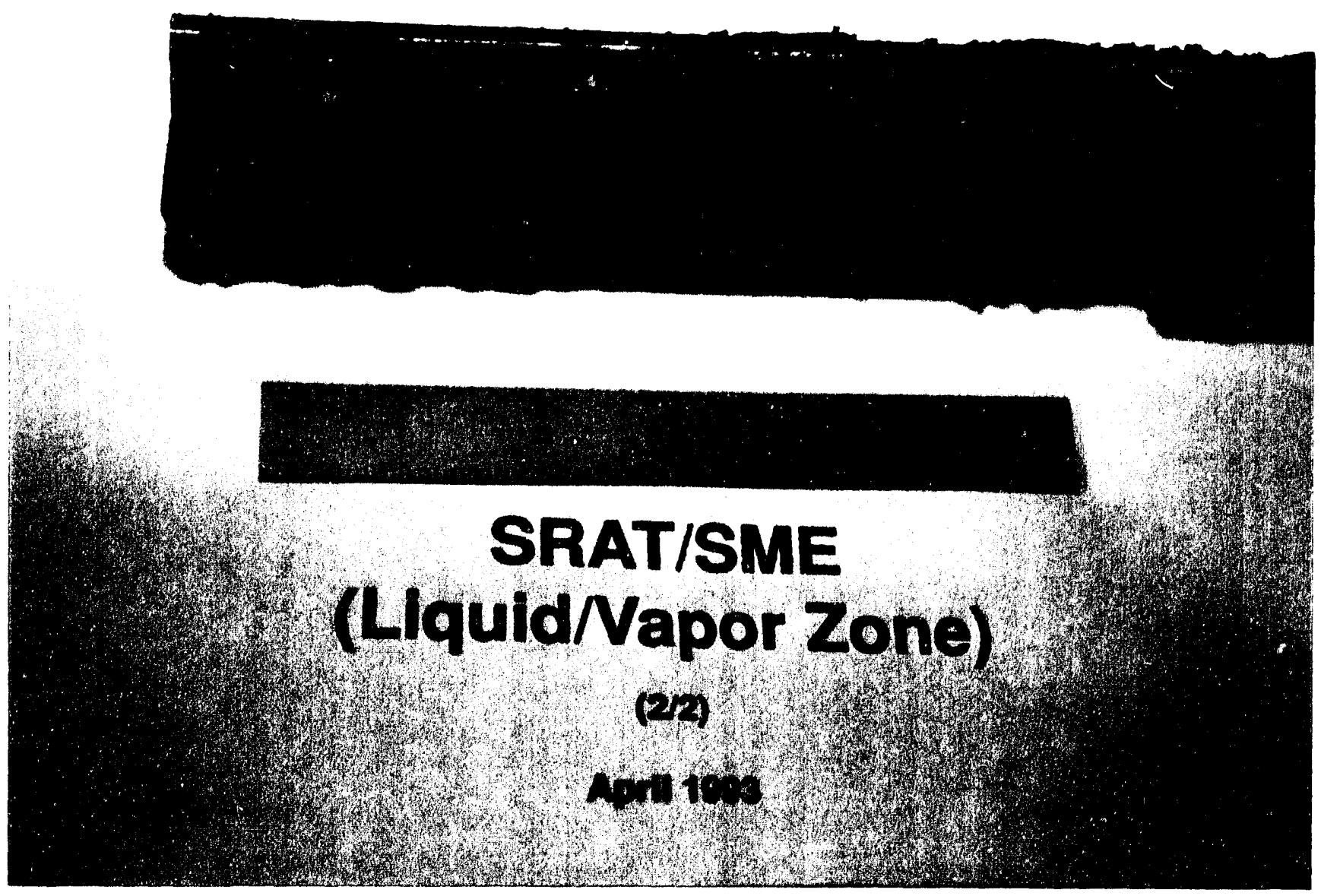

VAPQR

LIQUID/VAPDR

(TDP)

(BDT TOM)

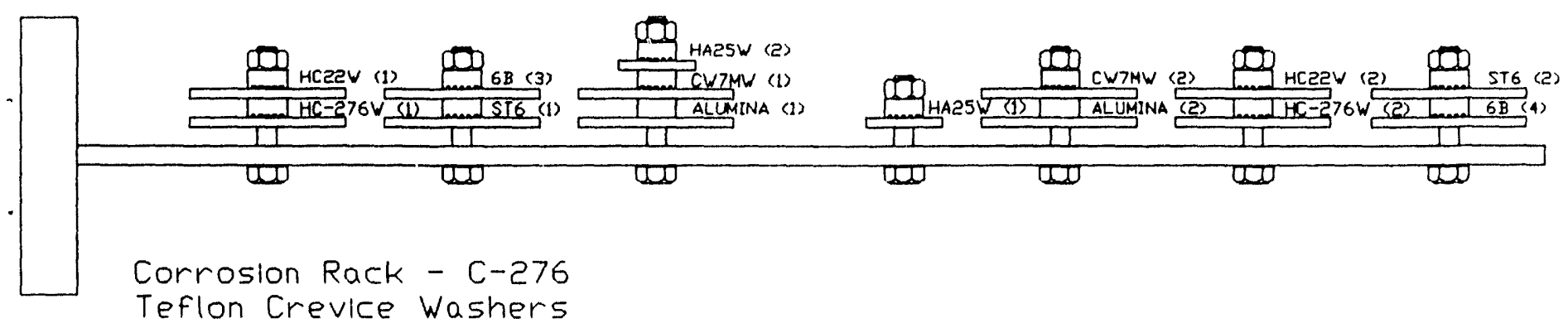


J. R. Zamecnik, 704-T

September 16, 1993

Page 29 of 65

WSRC-TR-93-461

\section{FIGURE 4}

SRAT/SME Vapor And Liquid/Vapor zone Corrosion Coupons Photograph Following cleaning with soap And water (Negative No. EE52535-A)

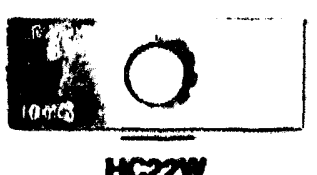

(1)

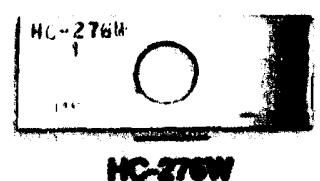

(i)

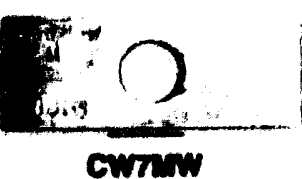

(1)

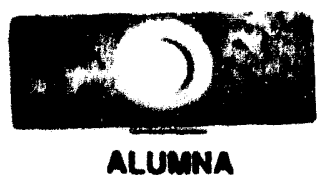

(1)

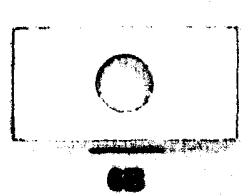

(a)

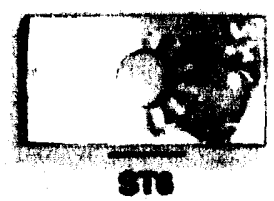

(1)

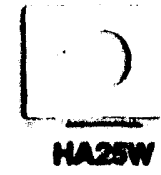

(2)

\section{SRAT/SME \\ (Vapor Space)}
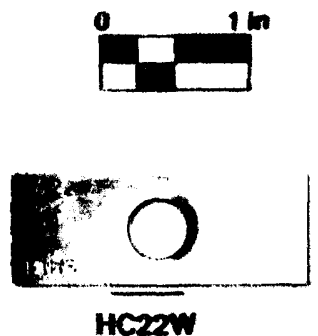

(2)

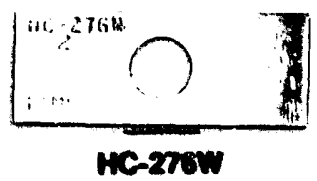

(a)

(1/2)

Aprill 1983

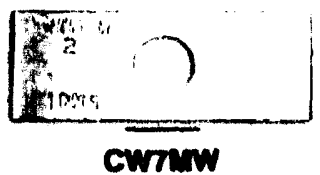

(2)
Materne trawoloar section

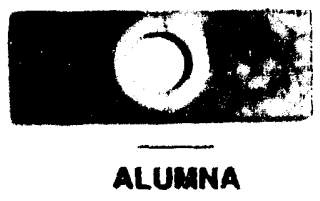

(2)

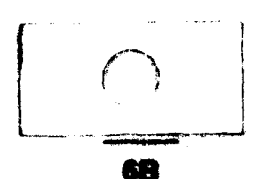

(A)

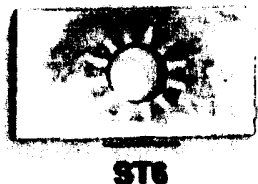

4

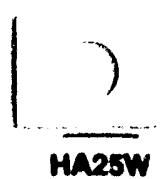

(1)

\section{SRAT/SME \\ (Liquid/Vapor Zone)}

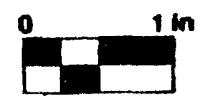

(2/2) 
J. R. Zamecnik, 704-T

September 16,1993

Page 30 of 65

WSRC-TR-93-461

\author{
FIGURE 5
}

8RAT/8ME Condenser Vapor Inlet corrosion Coupon Rack

Photograph Prior To Cleaning (Negative No. EE52534-A) and schematic showing Location of Coupons on Rack
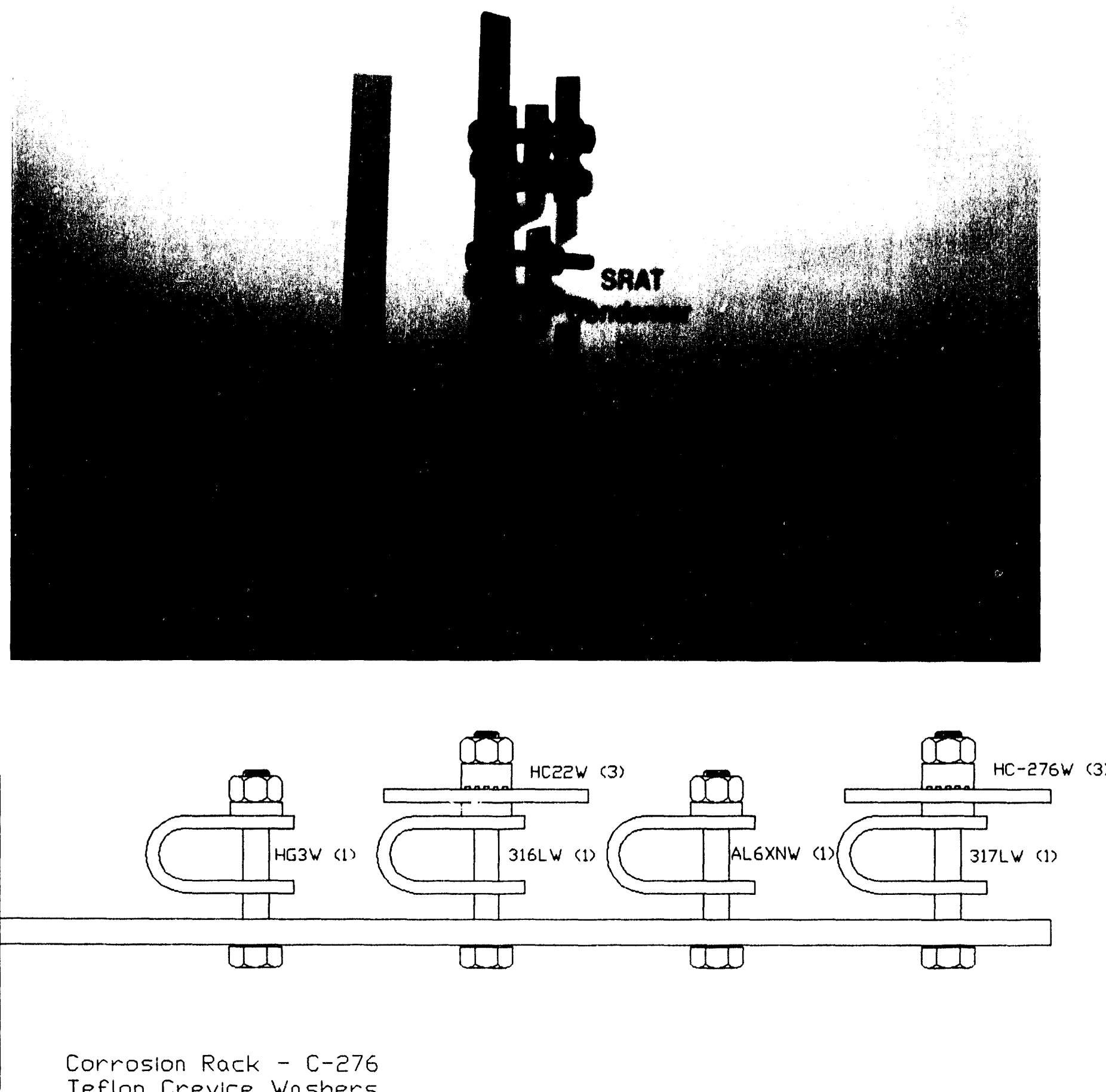

Teflon Crevice Washers 
J. R. Zamecnik, 704-T

September 16, 1993

Page 31 of 65

WSRC-TR-93-461

\section{FIGURE 6}

SRAT/BME Condenser Vapor Inlet Corrosion Coupons

Photograph Following cleaning with soap And water

(Negative No. EE52535-A)

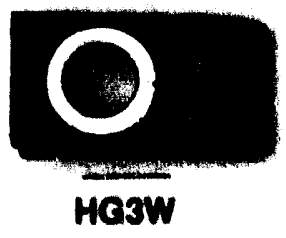

(1)

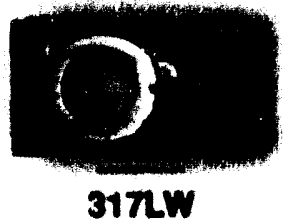

(1)

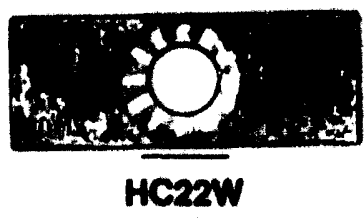

(3)

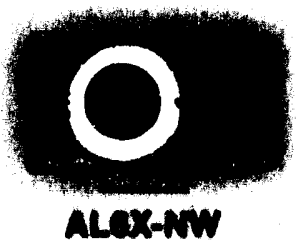

(1)

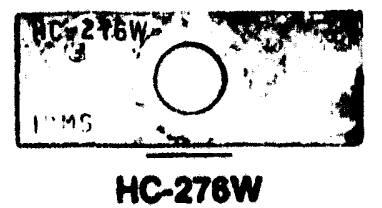

(3)

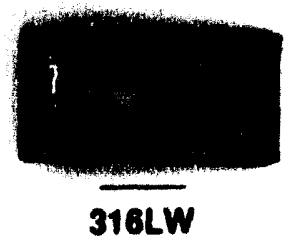

(1)

\section{SRAT \\ Condenser}

(1/1)

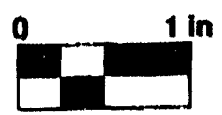

April 1993

MATERIALS TECHNOLOGY SEC1 
J. R. Zamecnik, 704-T

September 16,1993

Page 32 of 65

WSRC-TR-93-461

FIGURE 7

Mercury Water Wash Tank Corrosion Coupon Rack

Photograph Prior To Cleaning (Negative No. EE52534-A) and schematic showing Location of Coupons on Rack

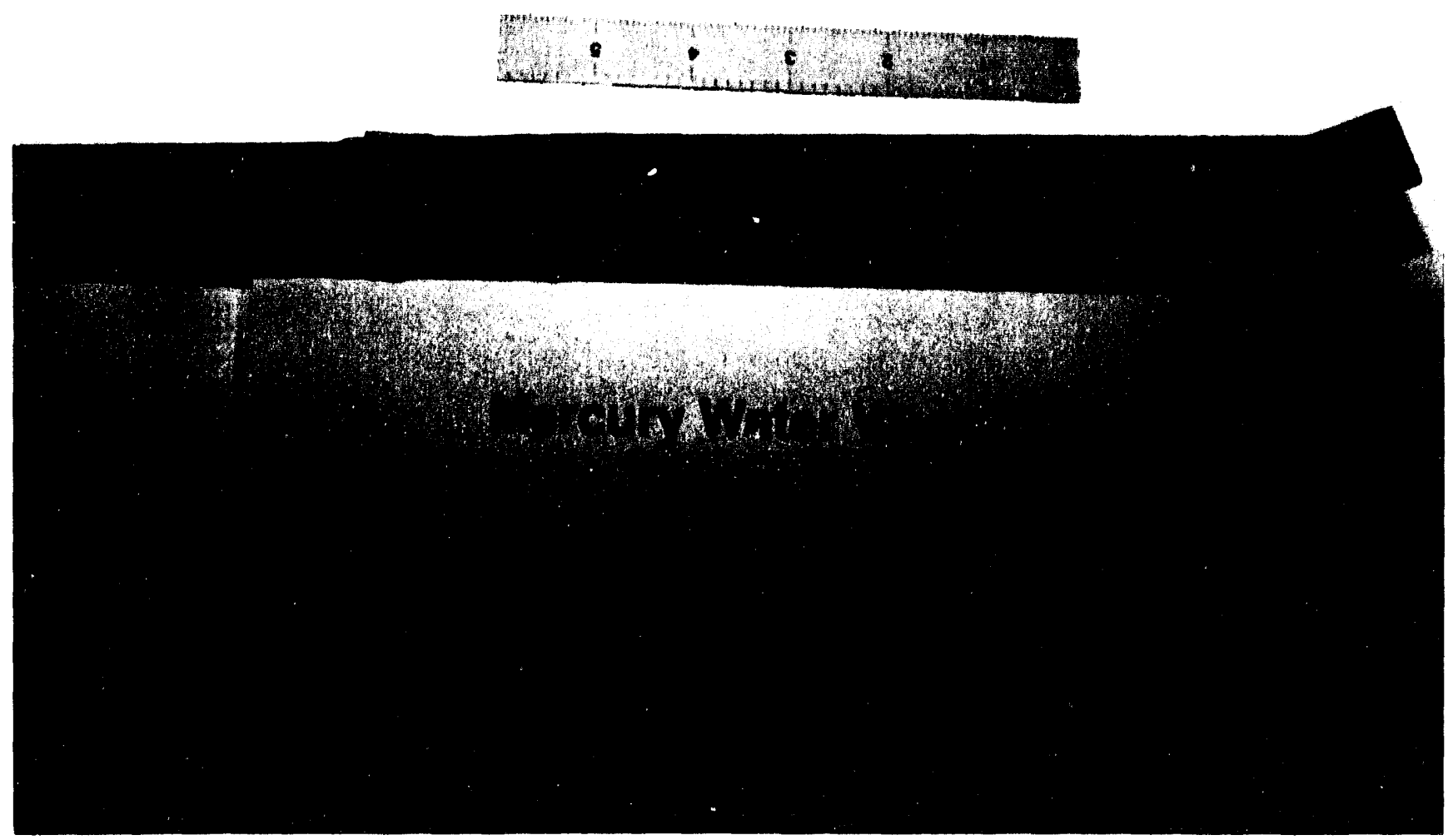

$\square$

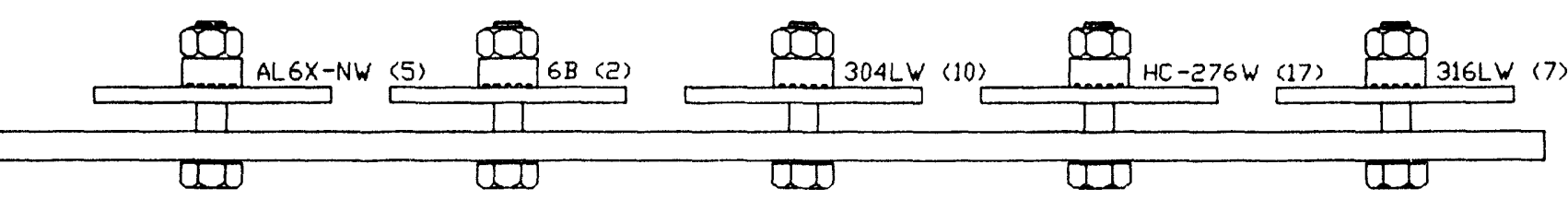

Corrosion Rack - 304L

Teflon Crevice washers 
J. R. Zamecnik, 704-T

September 16,1993

Page 33 of 65

WSRC-TR-93-461

FIGURE 8

Mercury Water Wash Tank Corrosion Coupons

Photograph Following cleaning with soap And water
(Negative No. EE52535-A)

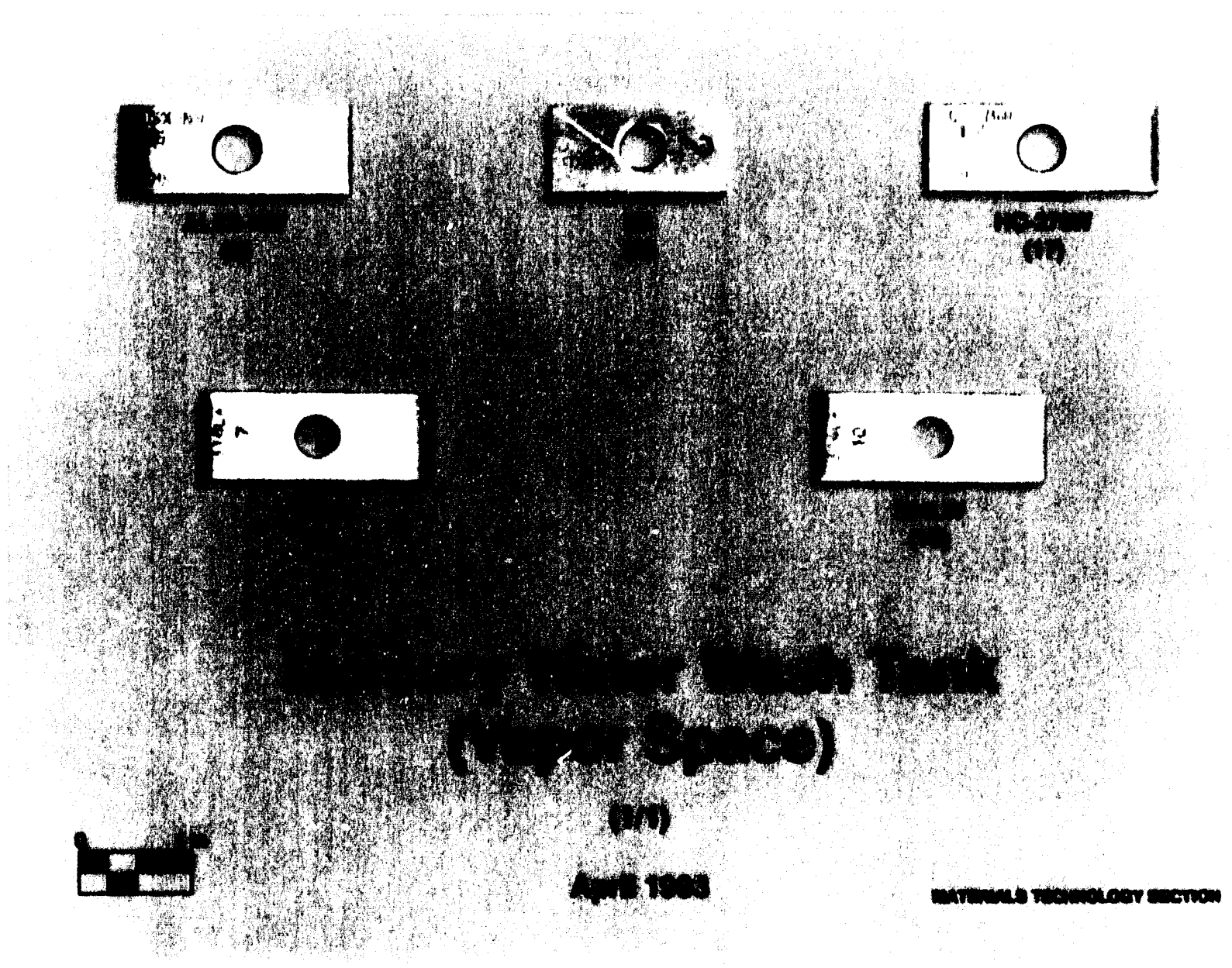


J. R. Zamecnik, 704-T

September 16,1993

Page 34 of 65

WSRC-TR $-93-461$

\section{FIGURE 9}

Melter Feed Tank Vapor space Corrosion Coupon Rack

Photograph Prior To Cleaning (Negative No. EE52534-A) and schematic showing Location of Coupons on Rack
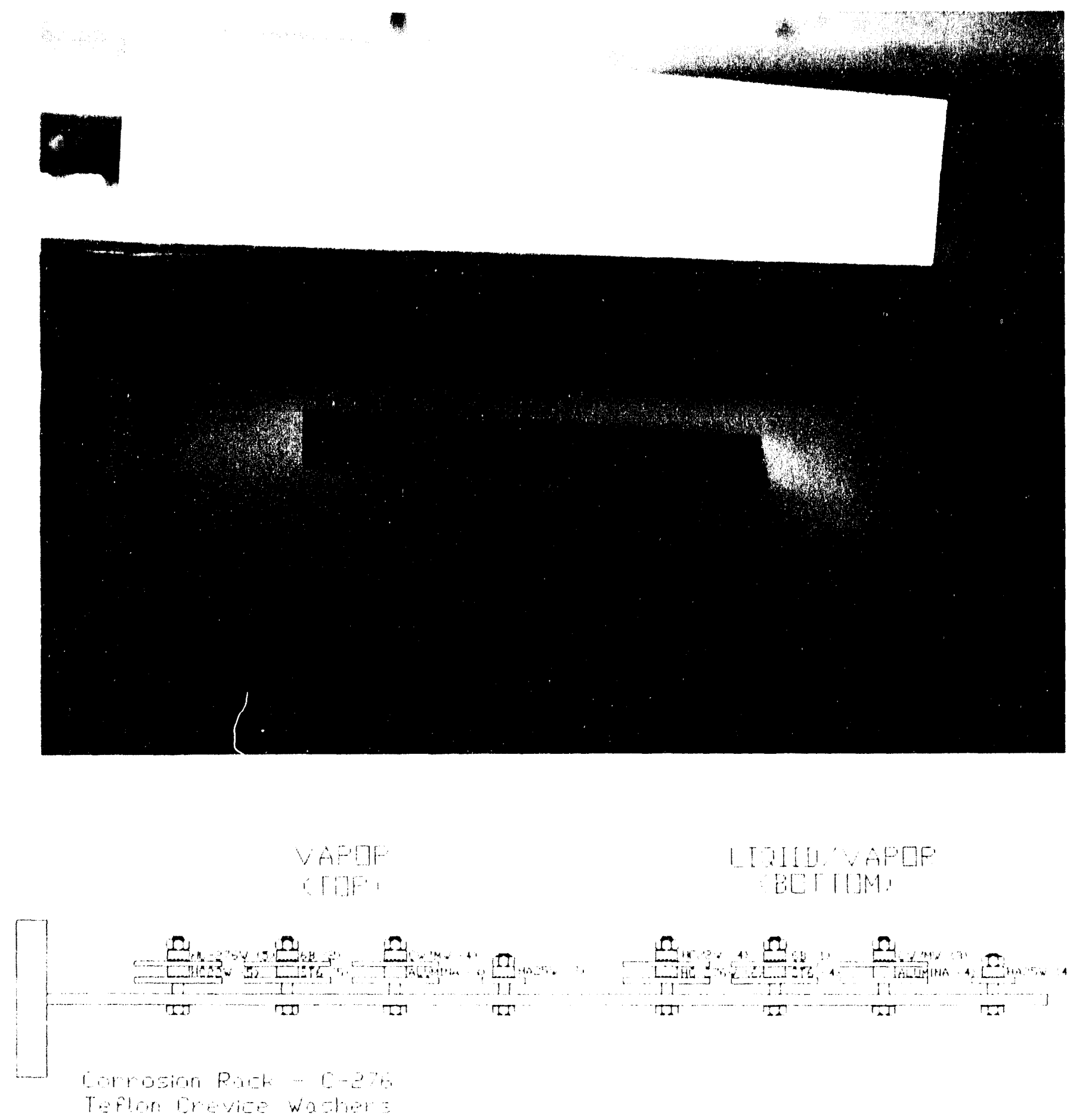
J. R. Zamecnik, 704-T

September 16,1993

page 35 of 65

WSRC-TR-93-461

FIGURE 10

Melter Feed Tank Liquid/Vapor zone corrosion Coupon Rack

Photograph Prior To Cleaning (Negative No. EE52534-A) and

schematic showing I,ocation of Coupons on Rack

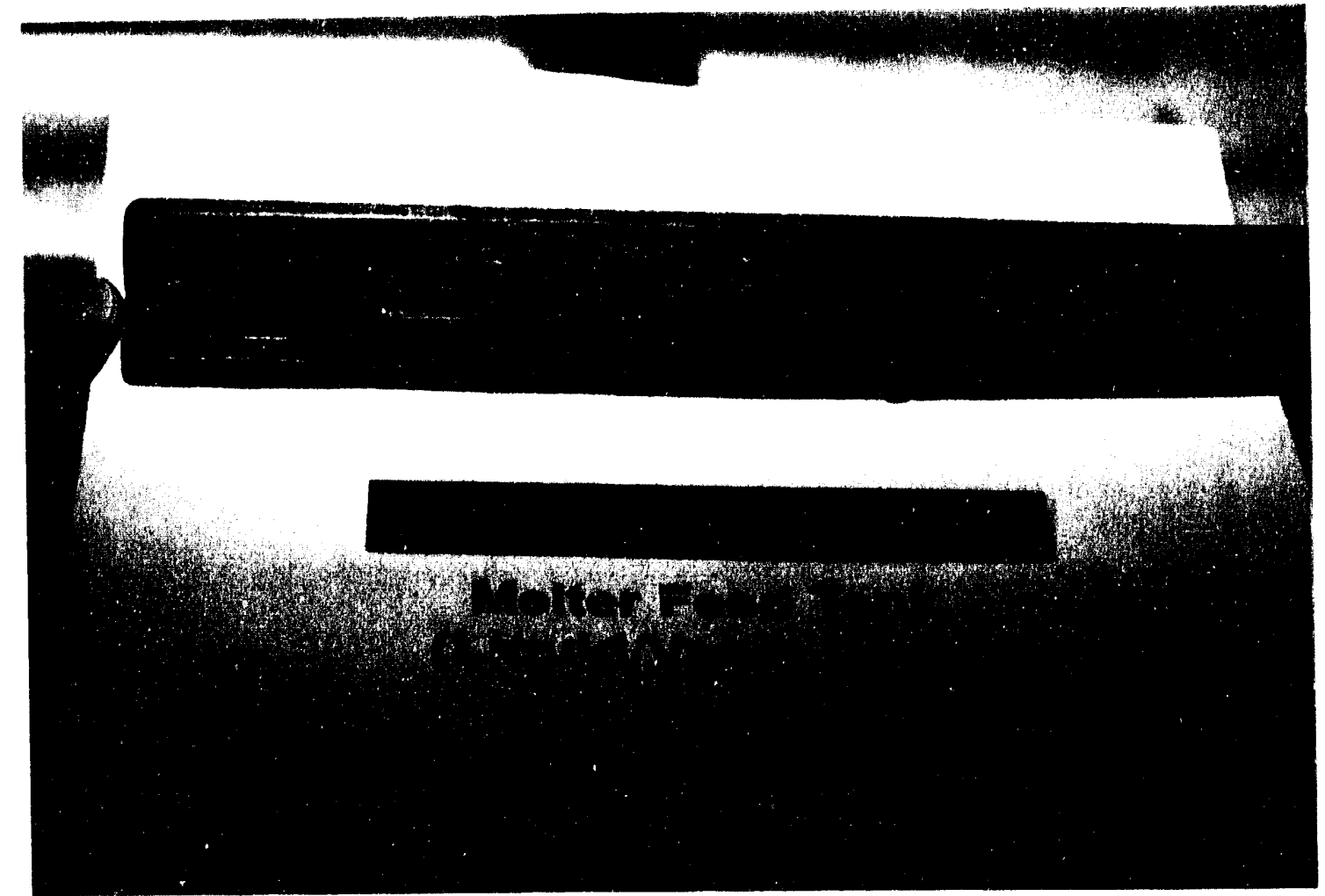

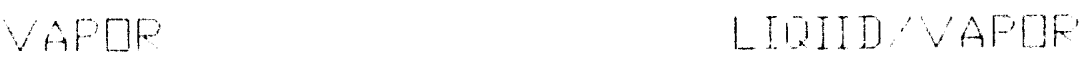

TDP

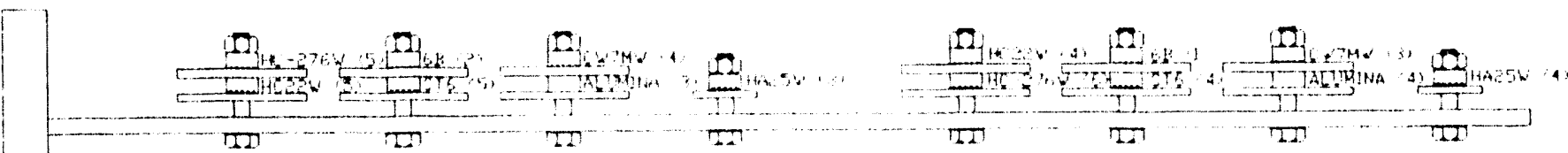

Eorrosion Fix -

Teflom Crevice wastor. 
J. R. Zamecnik, 704-T

September 16, 1993

Page 36 of 65

WSRC-TR-93-461

FIGURE 11

Melter Feed Tank Vapor space And Liquid/Vapor Zone Corrosion Coupons Photograph Following cleaning with soap and water (Negative No. EE52535-A)

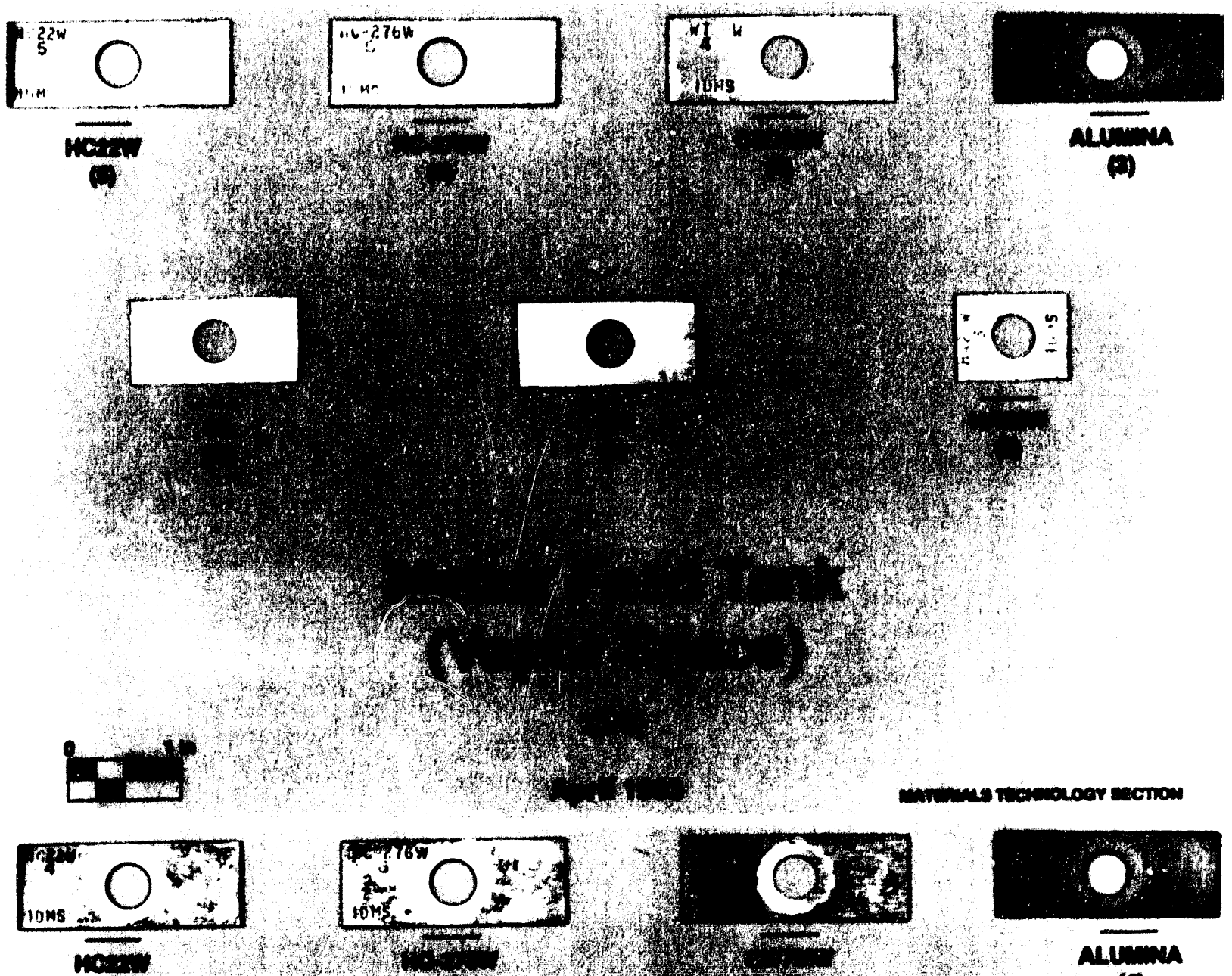

(a)

()

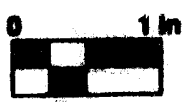


J. R. Zamecnik, 704-T

September 16, 1993

Page 37 of 65

WSRC-TR-93-461

FIGURE 12

Quencher Inlet corrosion Coupon Rack

Photograph Prior To cleaning (Negative No. EE52534-A) and schematic showing Location of Coupons on Rack
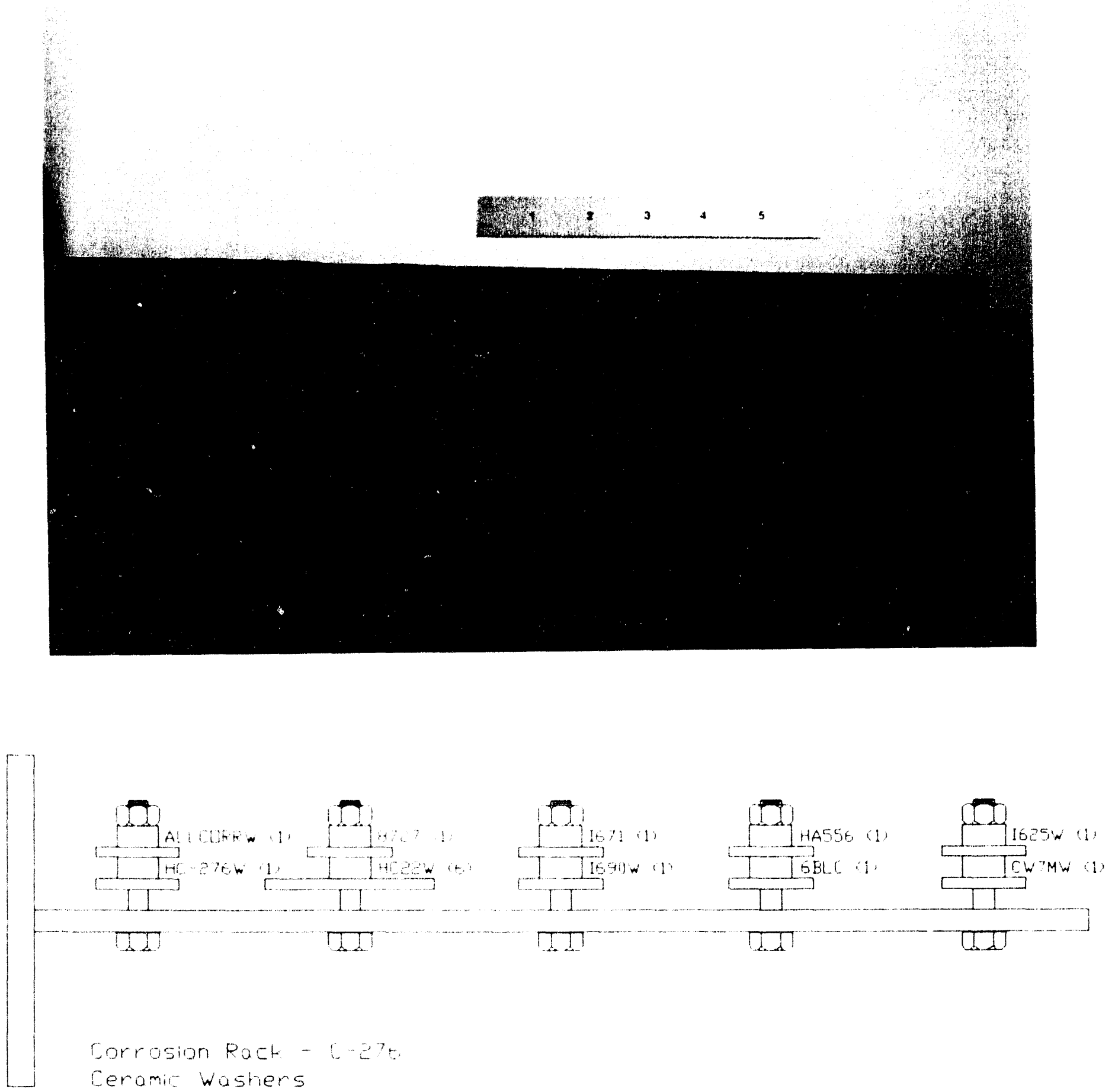
J. R. Zamecnik, 704-T

September 16,1993

Page 38 of 65

WSRC-TR-93-461

FIGURE 13

Quencher Inlet corrosion coupons

Photograph Following cleaning with soap And Water

(Negative No. EE52535-A)

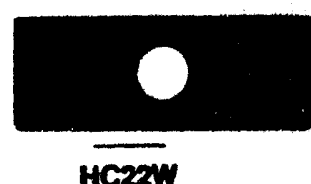

(0)

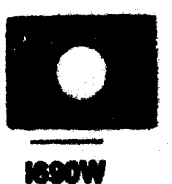

(1)

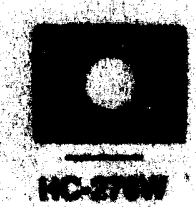

(i)

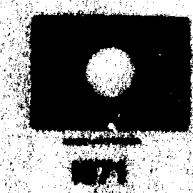

(1)

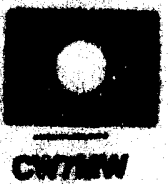

(i)

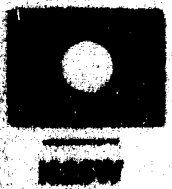

(a)

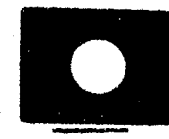

unoriw

(1)

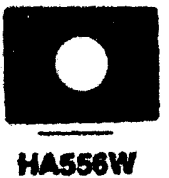

(1)

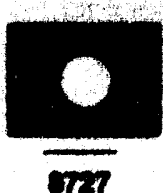

(1)

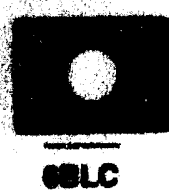

(1)

\section{Quencher \\ (Inlet)}

(1/1)

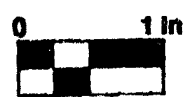

April 1993

MATERIALS TECHNOLOGY SECTION 
J. R. Zamecnik, 704-T

September 16, 1993

Page 39 of 65

WSRC-TR-93-461

FIGURE 14

Quencher Inlet Corrosion coupons

Photograph showing End-Grain Attack (Mag. 4X)

(Negative No. EE22529-A)

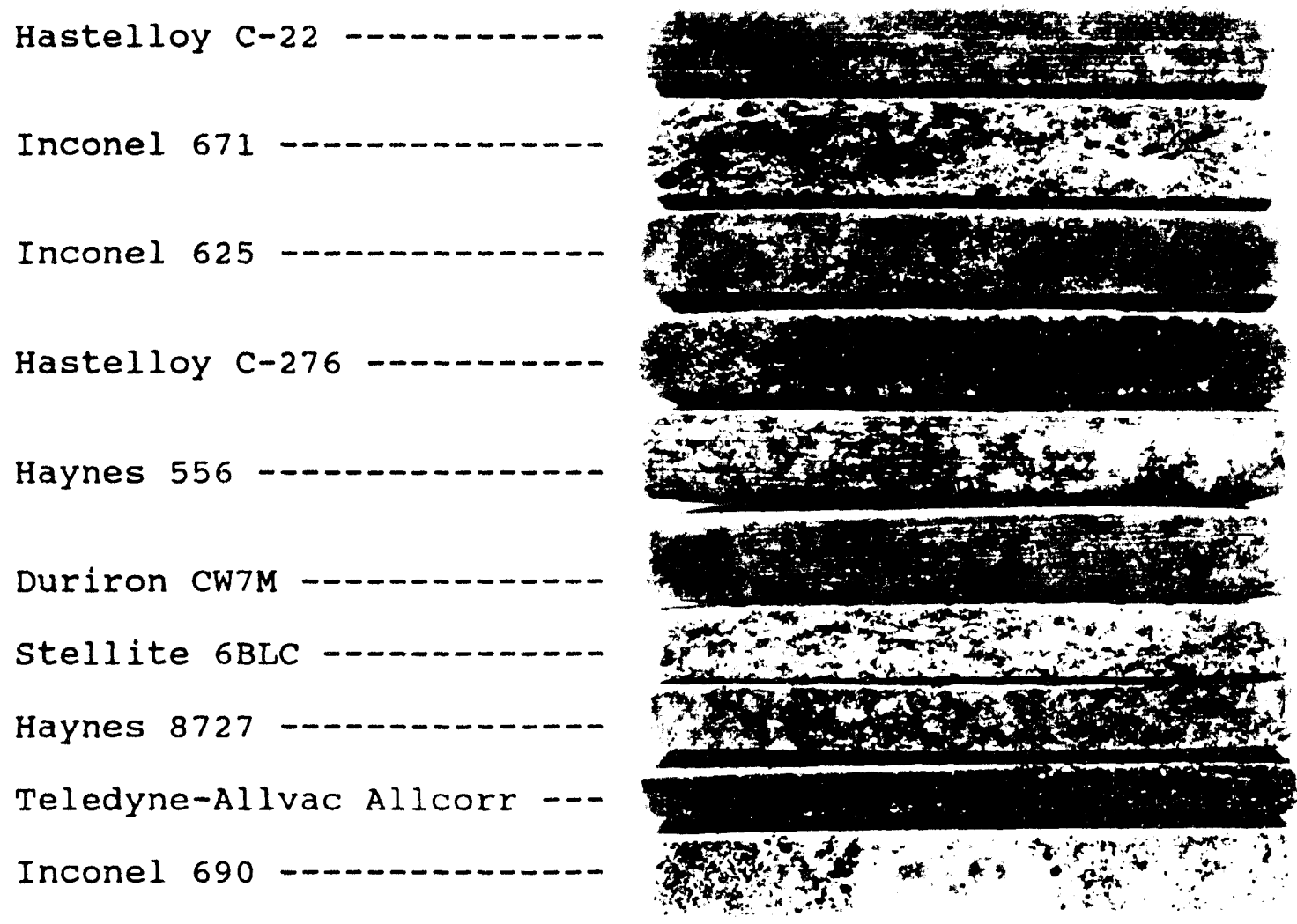


J. R. Zamecnik, 704-T

September 16, 1993

Page 40 of 65

WSRC-TR-93-461

FIGURES $15 \mathrm{a} \& \mathrm{~b}$

Quencher Inlet Corrosion Coupons

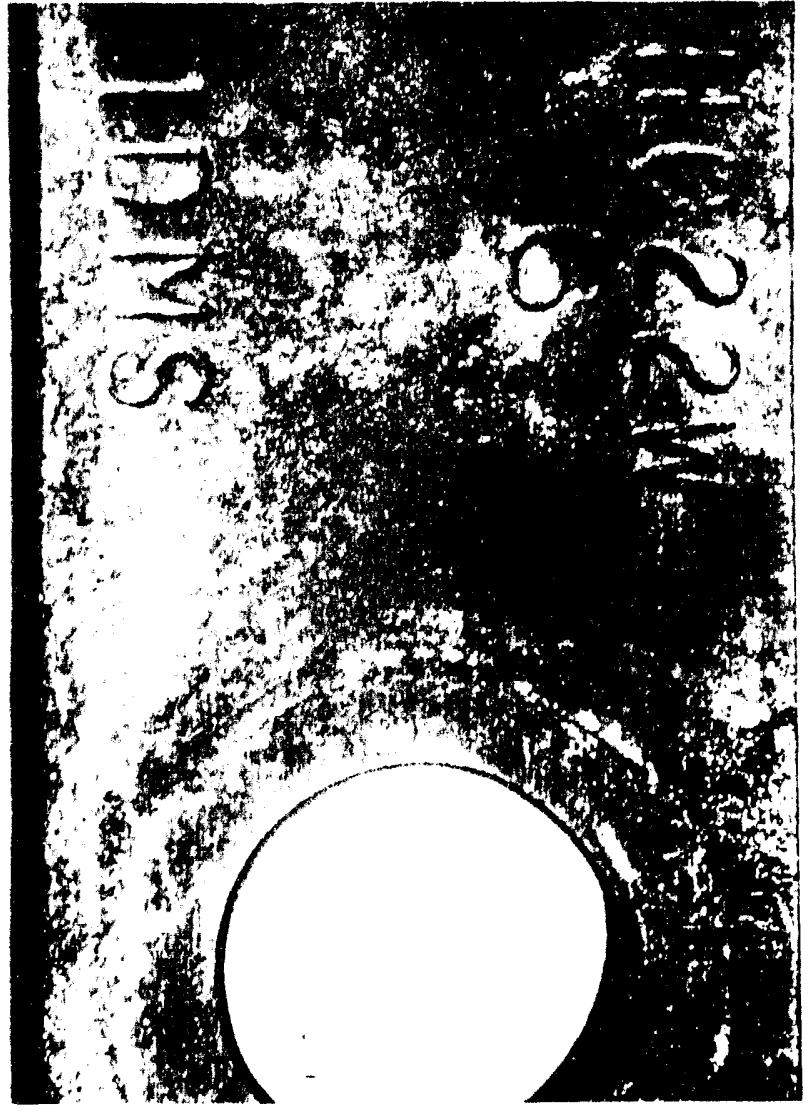

(Mag. 4X)

Figure 15a. Photograph Hastelloy C-22 coupon. Slight crevice attack is evident. (Negative No. EE22529-A).

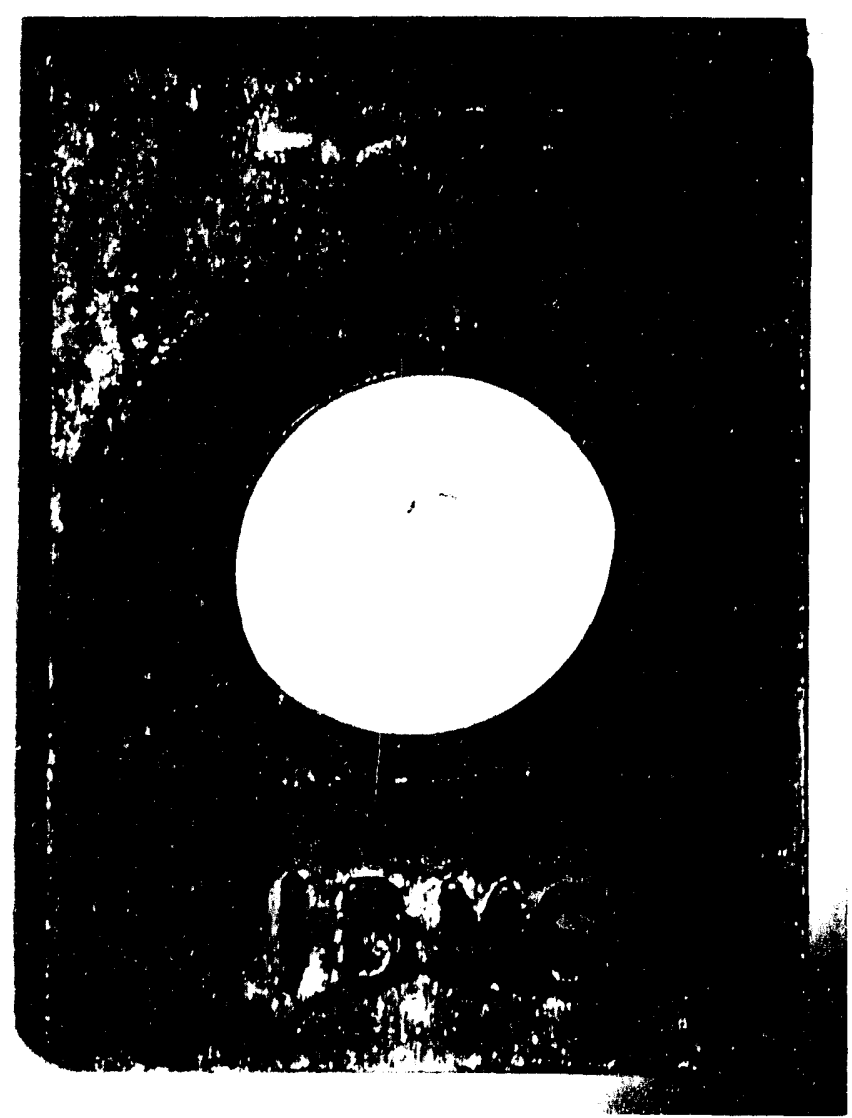

(Mag. 4X)

Figure 15b. Photograph of Inconel 625 coupon showing slight pitting attack. (Negative No. EE22529-A). 

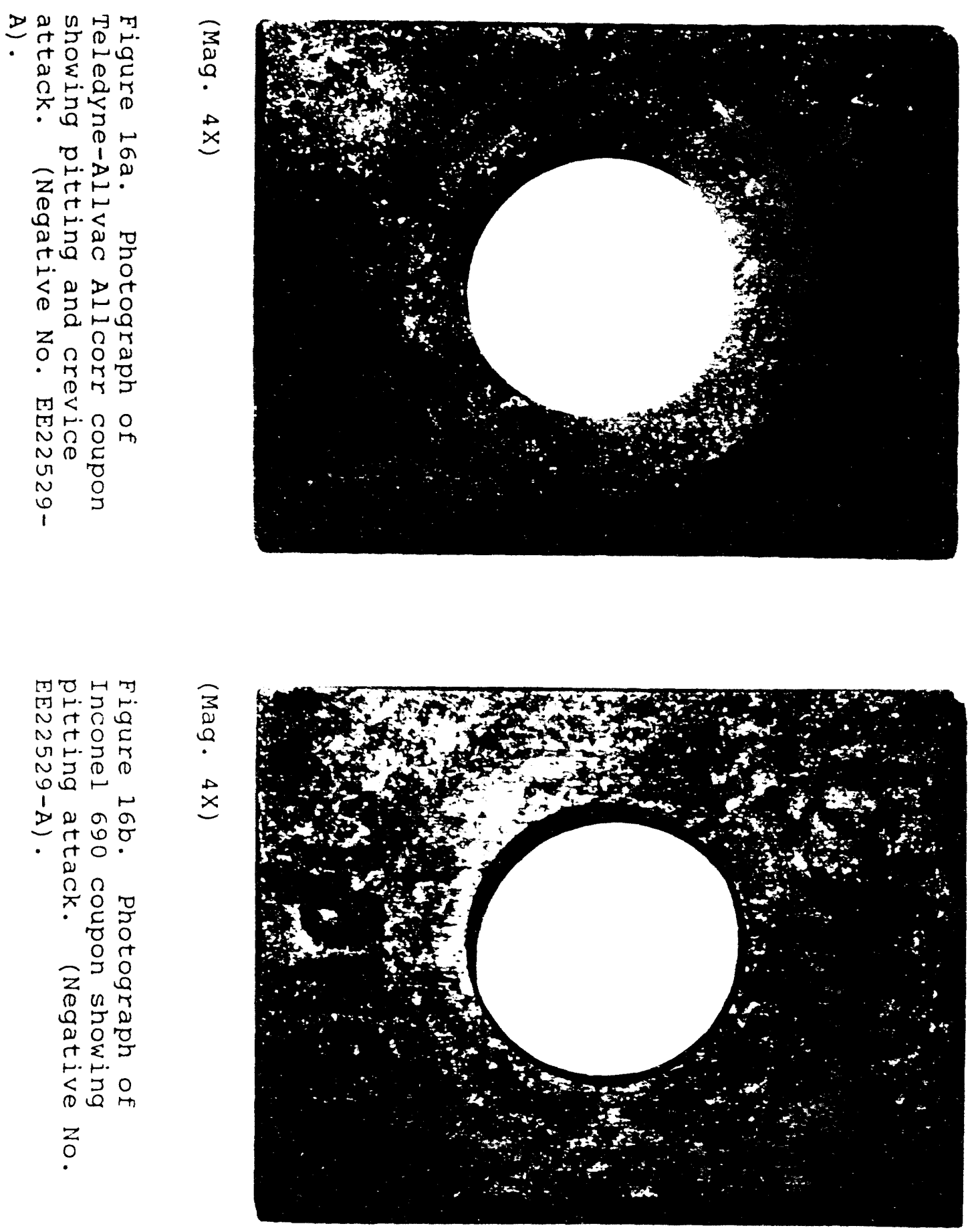
J. R. Zamecnik, 704-T

September 16,1993

Page 42 of 65

WSRC-TR-93-461

FIGURES $17 a \& b$

Quencher Inlet corrosion Coupons

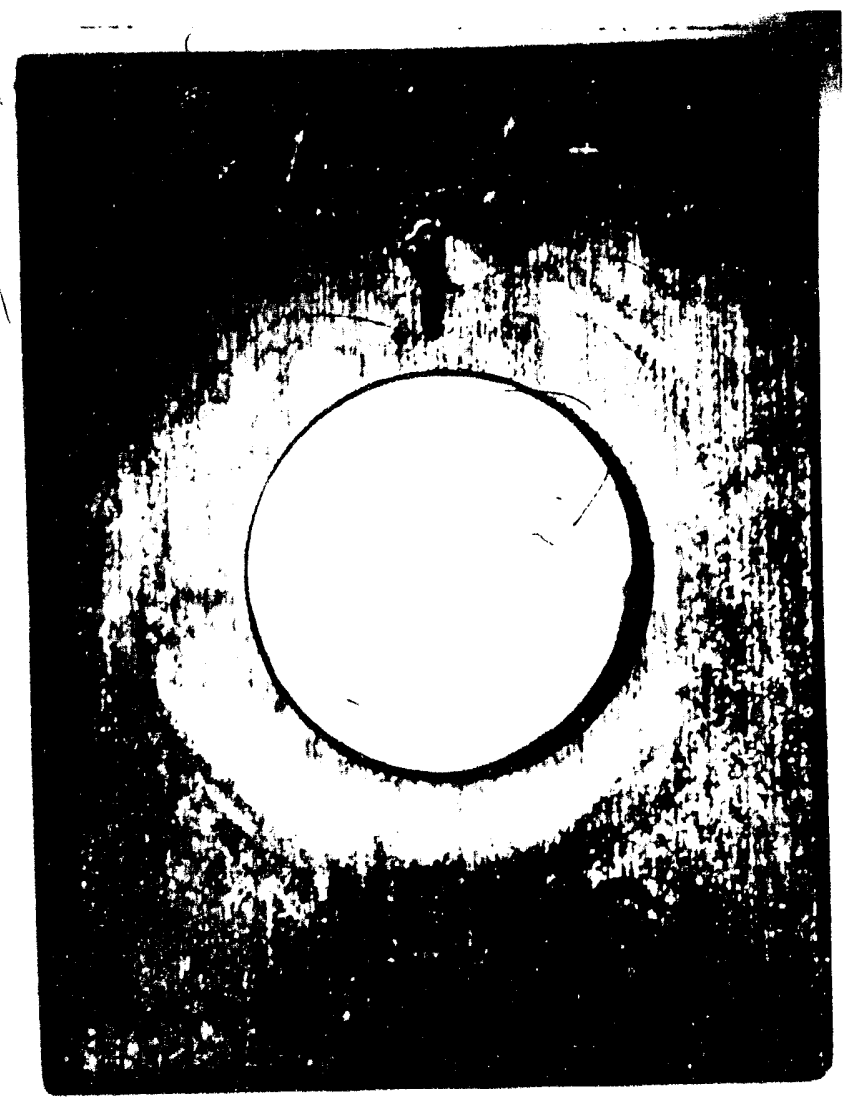

(Mag. 4X)

Figure 17a. Photograph Duriron CW7M coupon showing some pitting outside ceramic washer. (Negative No. EE22529-A).

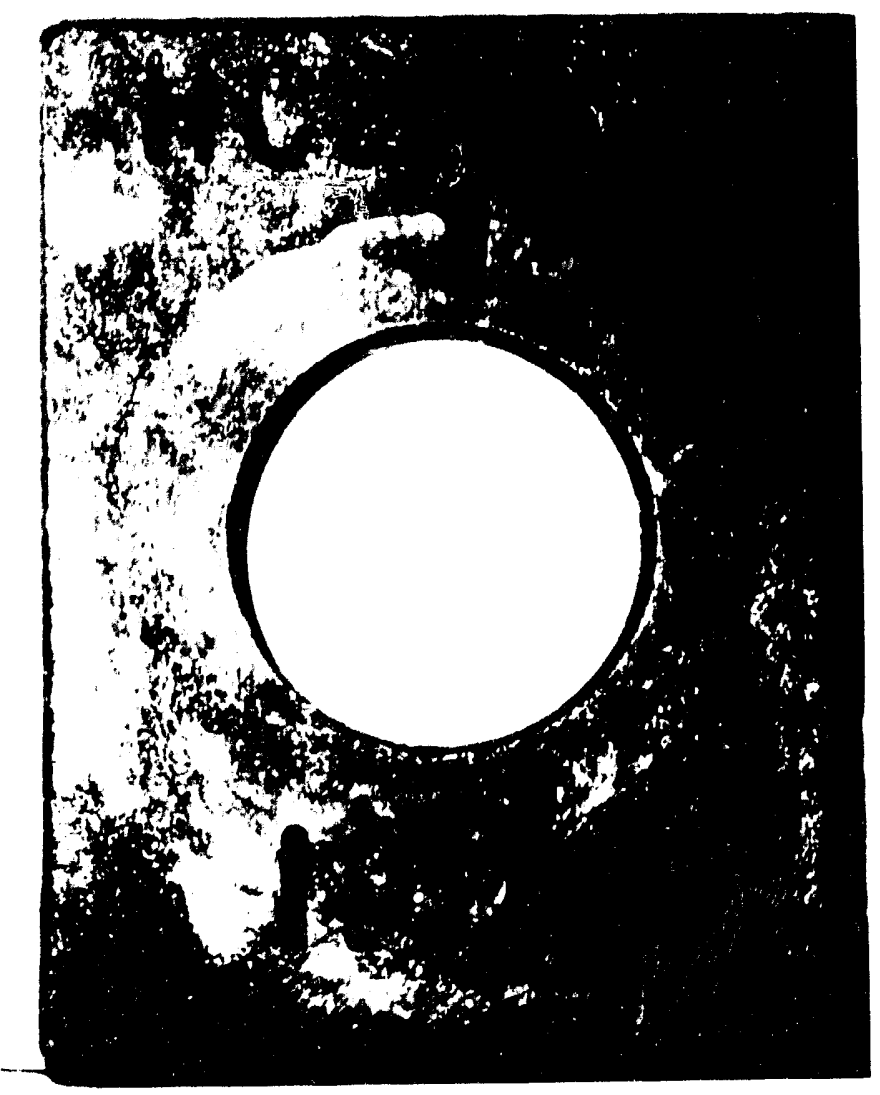

(Mag. 4X)

Figure 17b. Photograph of Hastelloy C-276 coupon showing mainly general corrosive attack. (Negative No. EE22529A). 
J. R. Zamecnik, 704-T

September 16, 1993

Page 43 of 65

WSRC-TR-93-461

FIGURES $18 \mathrm{a} \& \mathrm{~b}$

Quencher Inlet corrosion Coupons

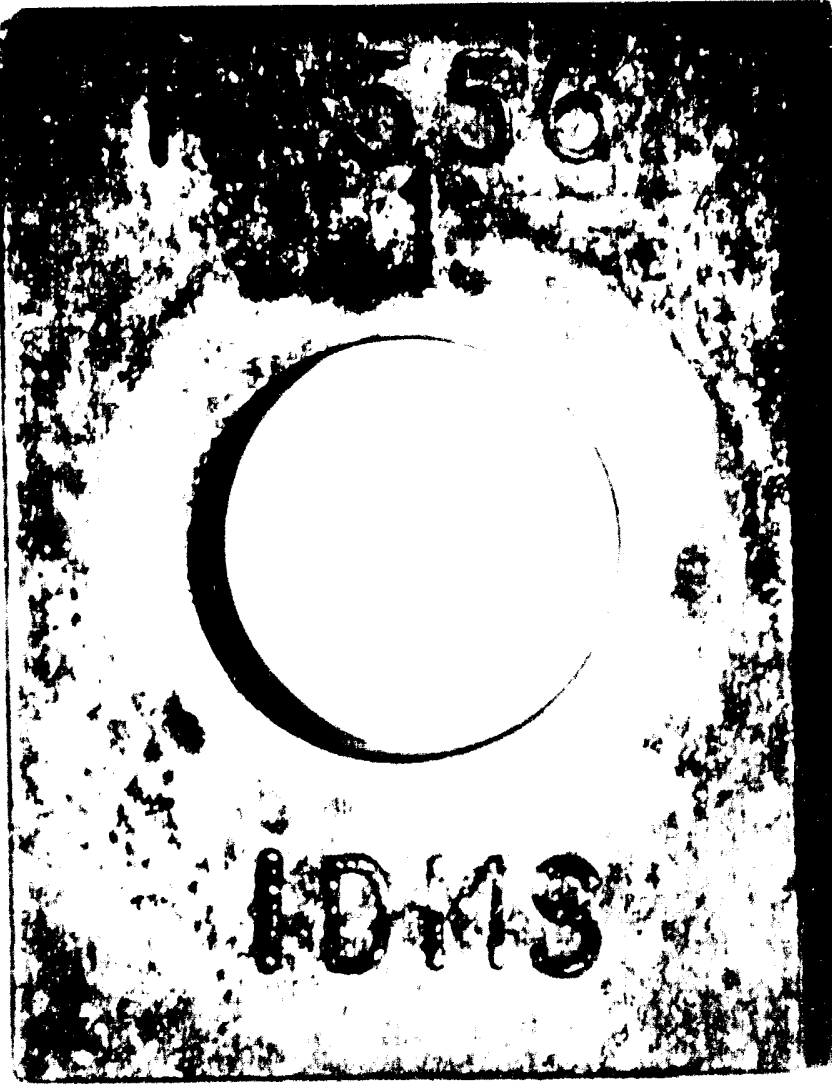

(Mag. 4X)

Figure 18a. Photograph of Haynes 556 coupon showing pitting and crevice attack. (Negative No. EE22529-A).

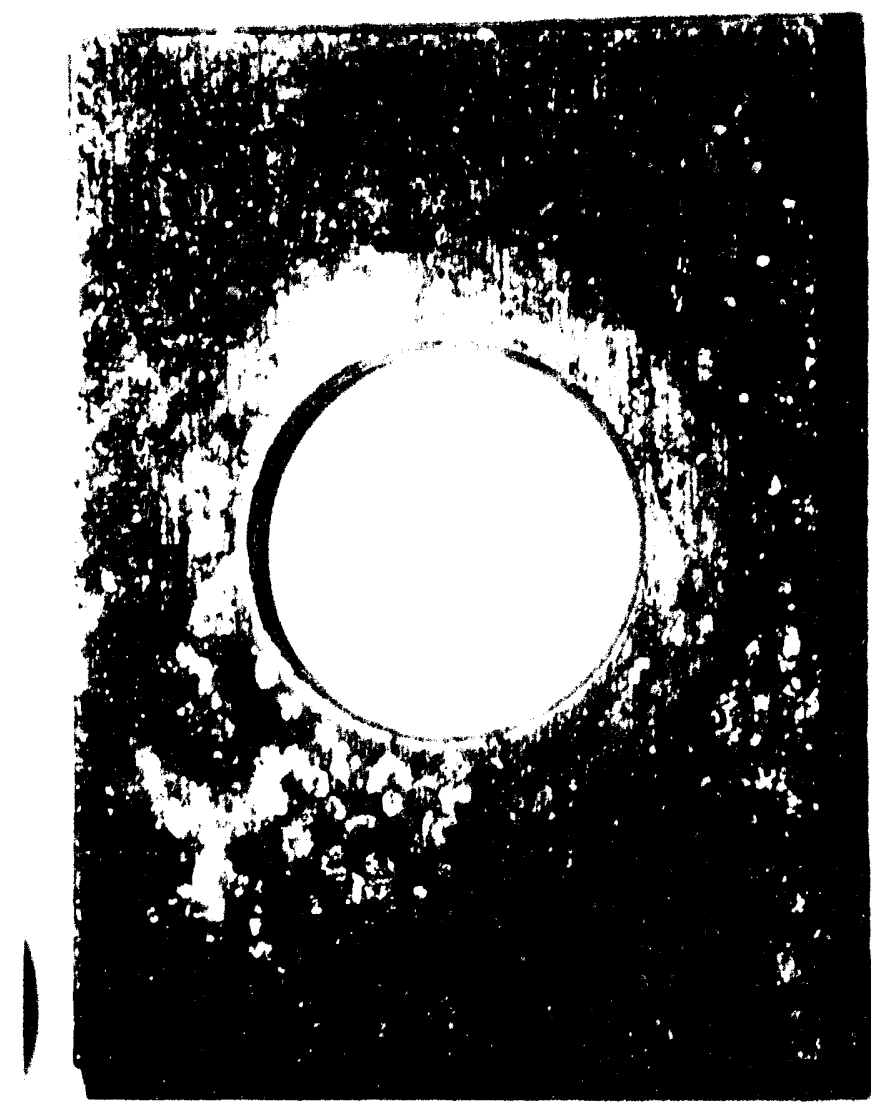

(Mag. 4X)

Figure 18b. Photograph of Inconel 671 showing pitting generally outside washer

region. (Negative No. EE22529A) . 
J. R. Zamecnik, 704-T

September 16, 1993

Page 44 of 65

WSRC-TR-93-461

FIGURES $19 a \& b$

Quencher Inlet corrosion Coupons

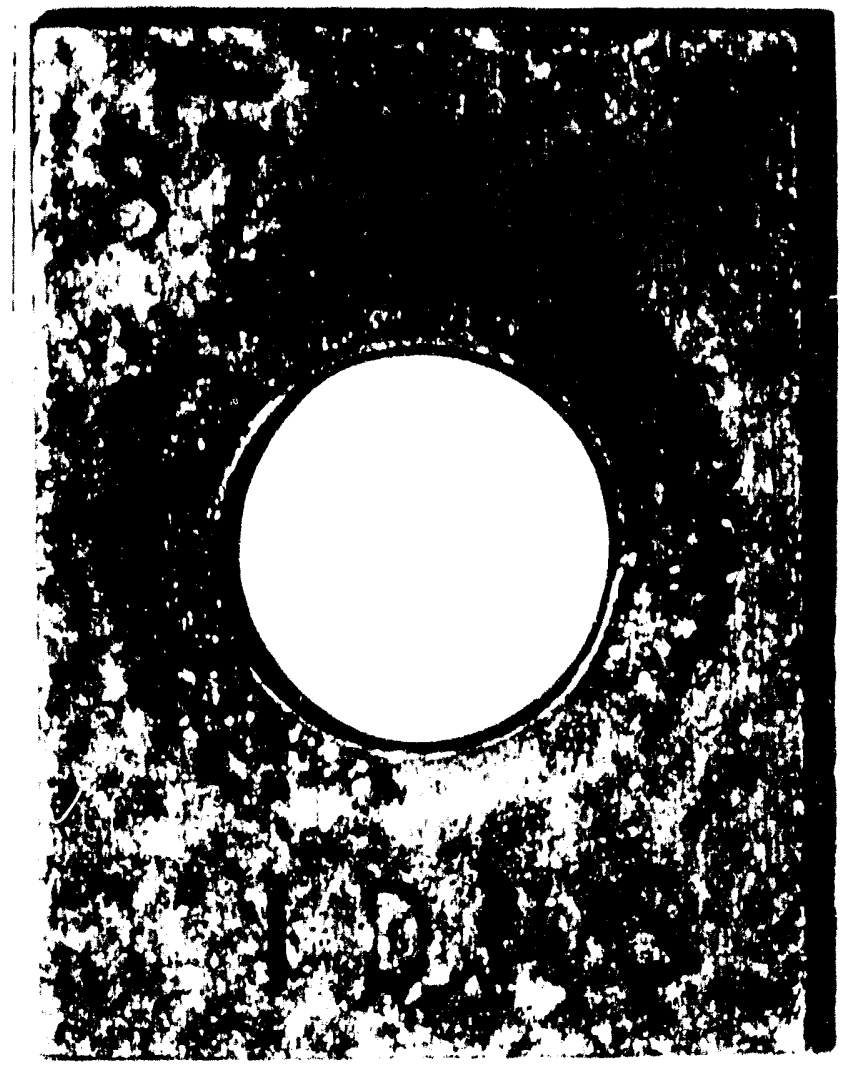

(Mag. 4X)

Figure 19a. Photograph of Haynes 8727 coupon showing some pitting and general non-uniform corrosion. (Negative No. EE22529-A).

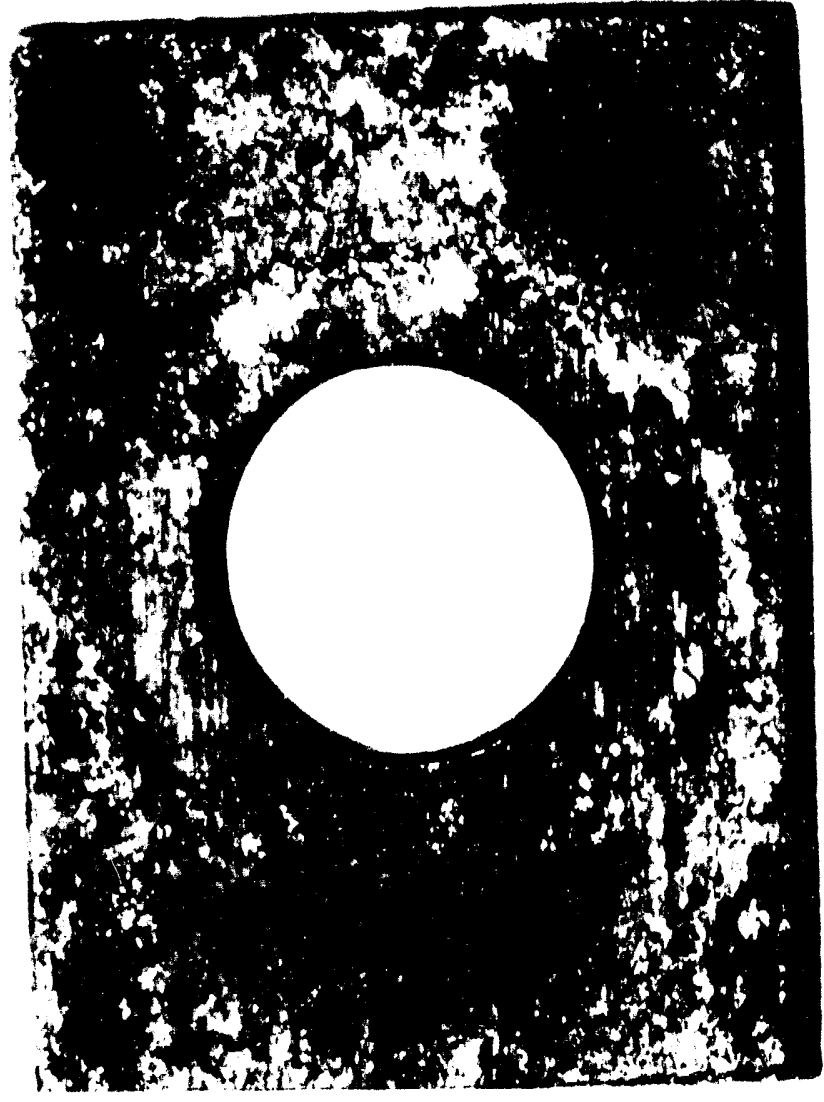

(Mag. 4X)

Figure 19b. Photograph of stellite 6BLC coupon showing severe pitting outside and underneath washer. (Negative No. EE22529-A). 
J. R. Zamecnik, 704-T

September 16, 1993

Page 45 of 65

WSRC-TR-93-461

FIGURES $20 a \& b$

Quencher Inlet Inconel 690 Corrosion Coupon

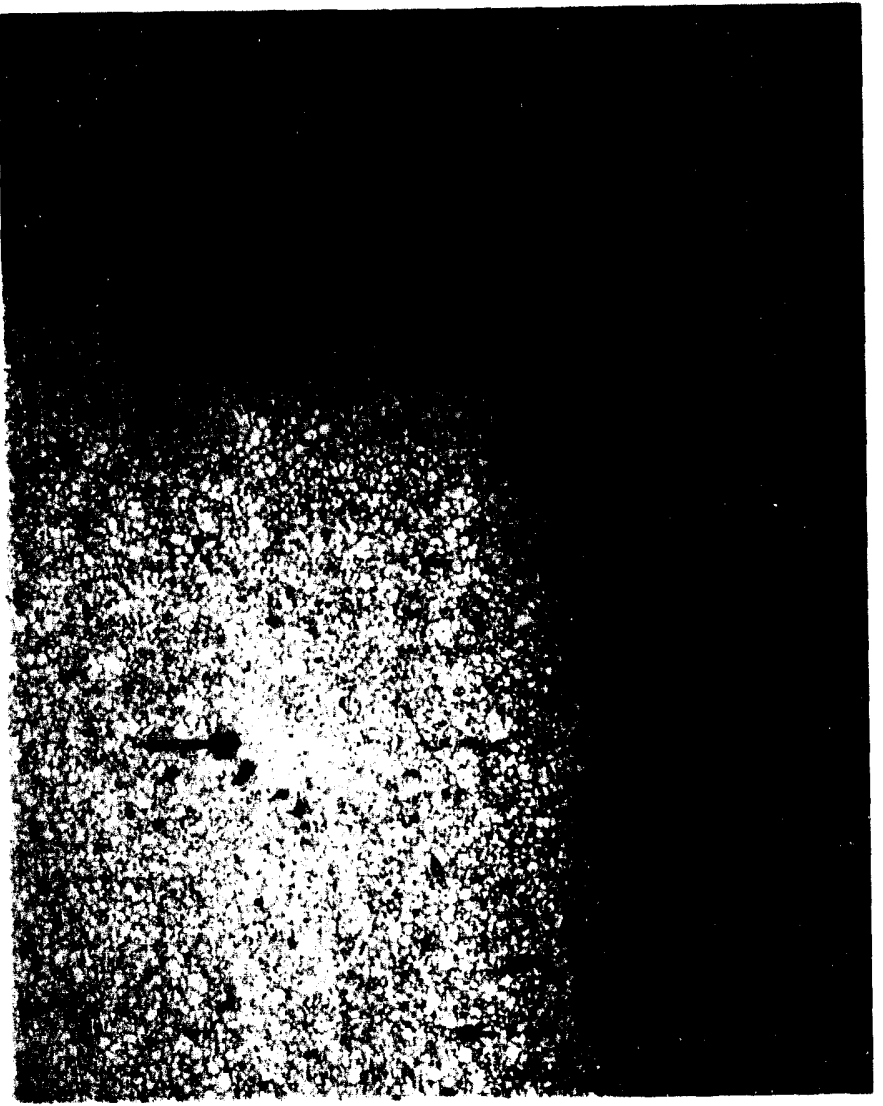

(Mag. 40X)

Figure 20a. Photomicrograph exhibiting localized corrosion of Inconel 690 coupon. Endgrain attack is shown on left edge (Etch 5\% Nital, 6 Volts). (Negative No. EE52599-A).

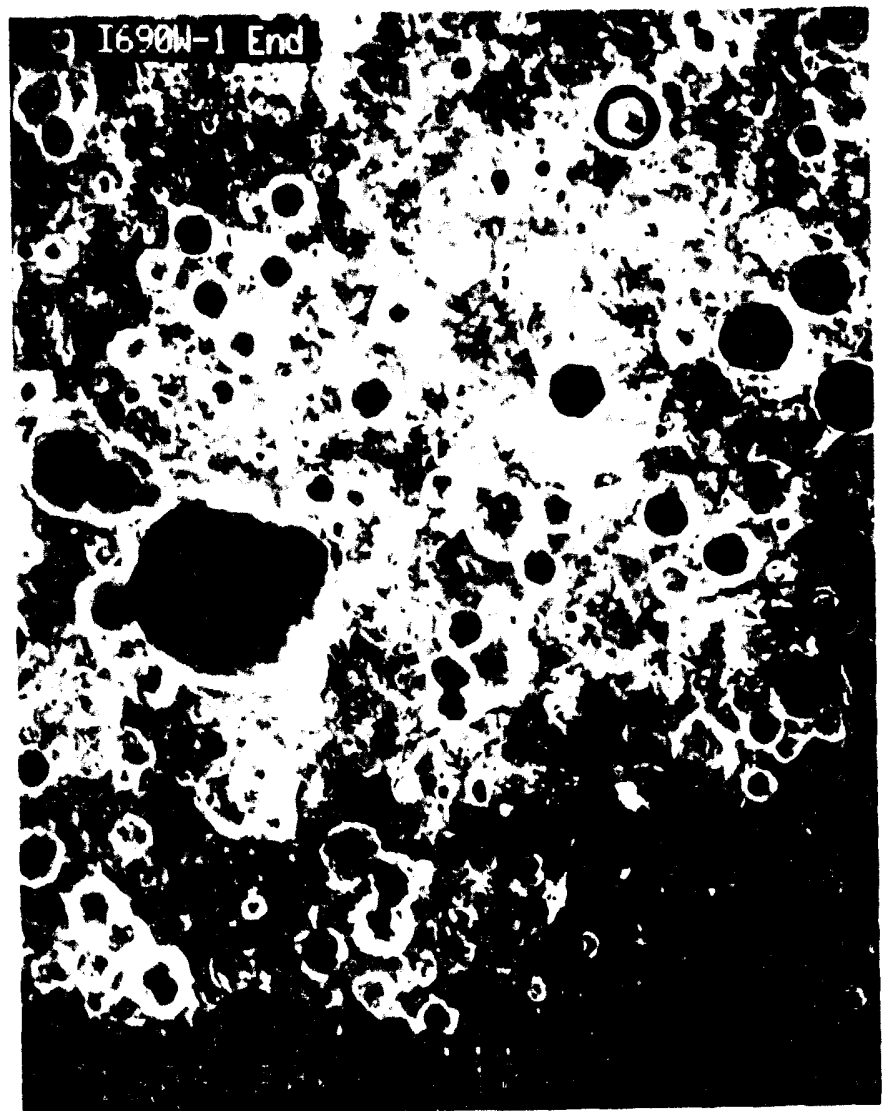

(Mag. 100X)

Figure 20a. SEM image showing severe end-grain attack of Inconel 690 coupon. (Negative No. EE22544-A). 
J. R. Zamecnik, 704-T

September 16, 1993

Page 46 of 65

WSRC-TR-93-461

FIGURES $21 a \& b$

Quencher Inlet Teledyne-Allvac Allcorr Corrosion Coupon

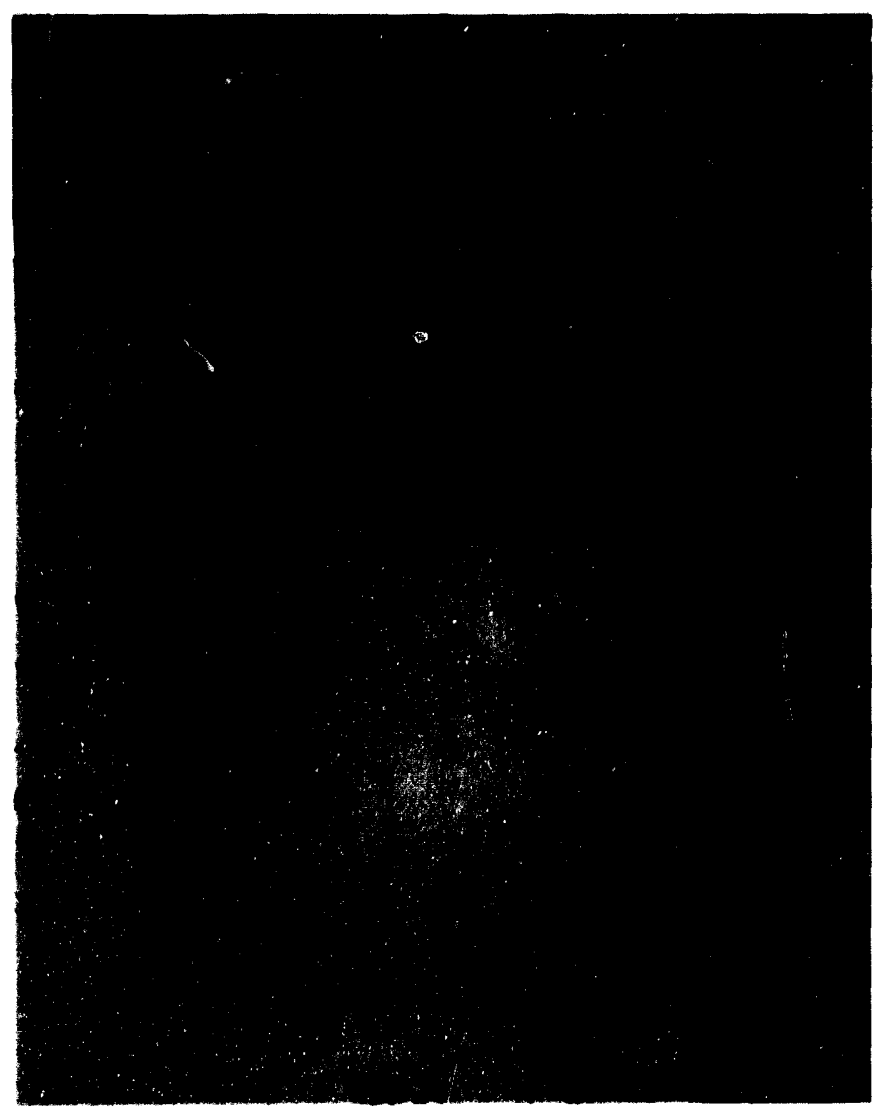

(Mag. 40X)

Figure 21a. Photomicrograph showing pitting corrosion of Allcorr coupon (Etch 5\% Nital, 6 volts). (Negative No. EE52598-A).

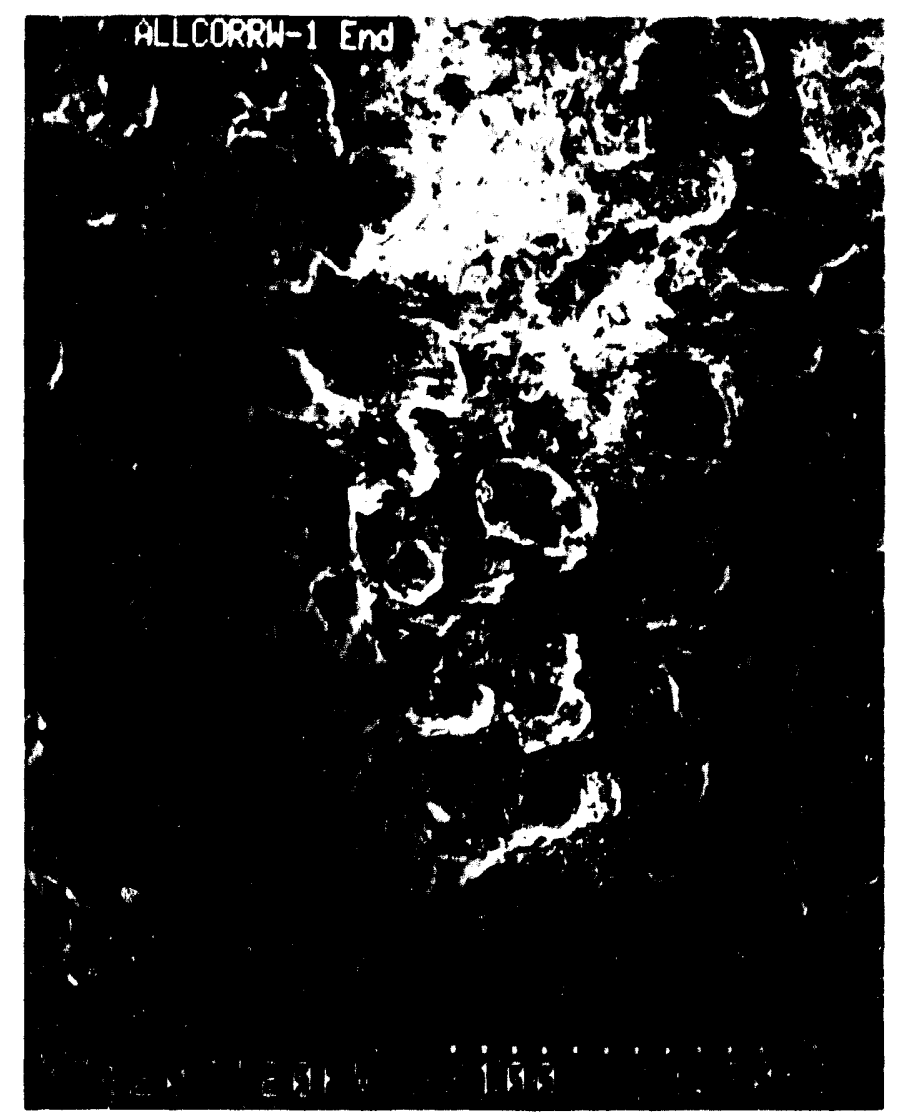

(Mag. 100X)

Figure 21b. SEM image showing end of Allcorr coupon.

(Negative No. EE22544-A). 
J. R. Zamecnik, 704-T

September 16, 1993

Page 47 of 65

WSRC-TR-93-461

FIGURE 22

Quencher outlet Corrosion Coupon Rack

Photograph Prior To Cleaning (Negative No. EE52534-A) and

schematic showing Location of Coupons on Rack

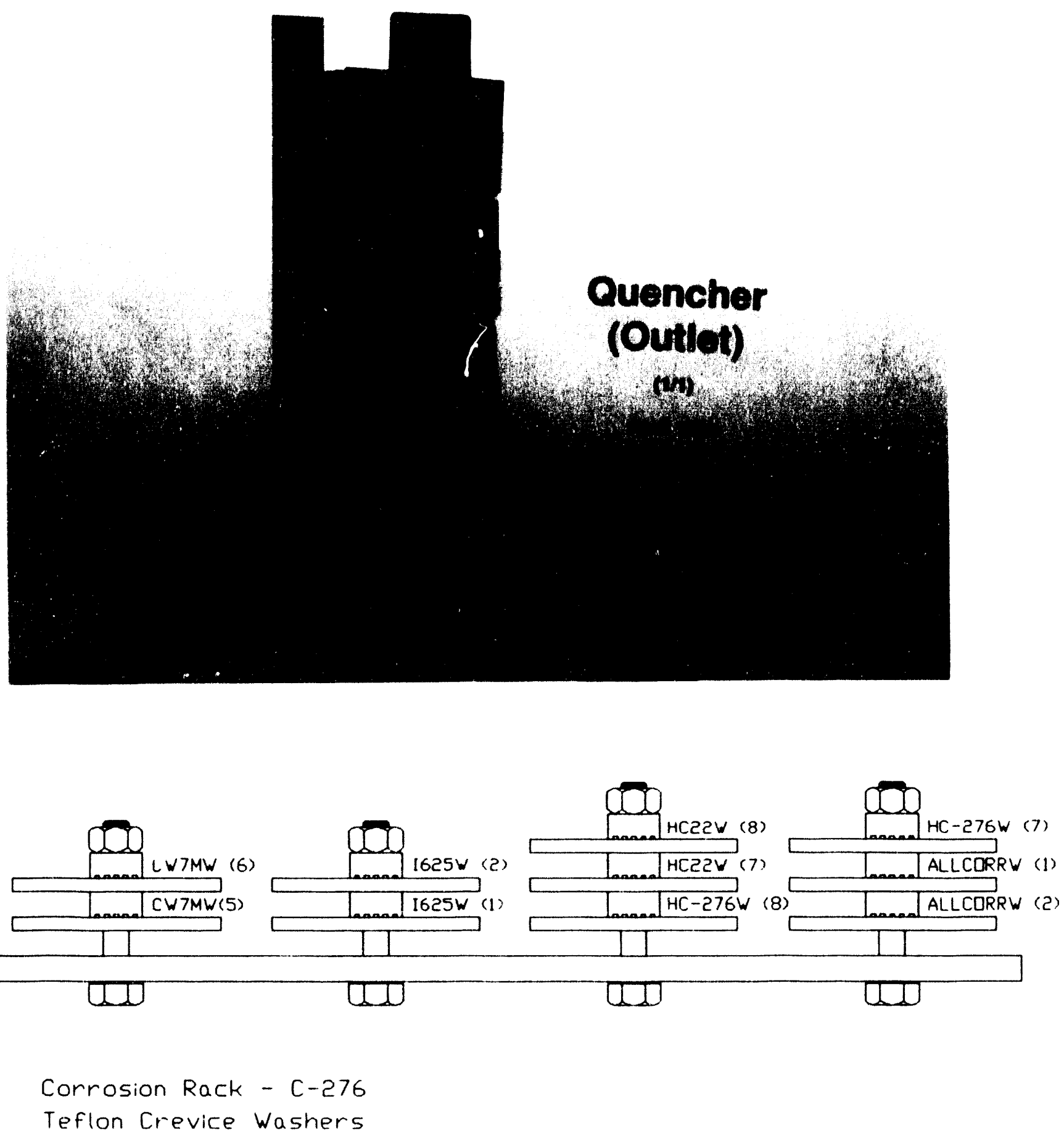


J. R. Zamecnik, 704-T

September 16,1993

Page 48 of 65

WSRC-TR-93-461

\section{FIGURE 23}

Quencher outlet corrosion Coupons

\section{Photograph Following cleaning with soap And water \\ (Negative No. EE52535-A)}

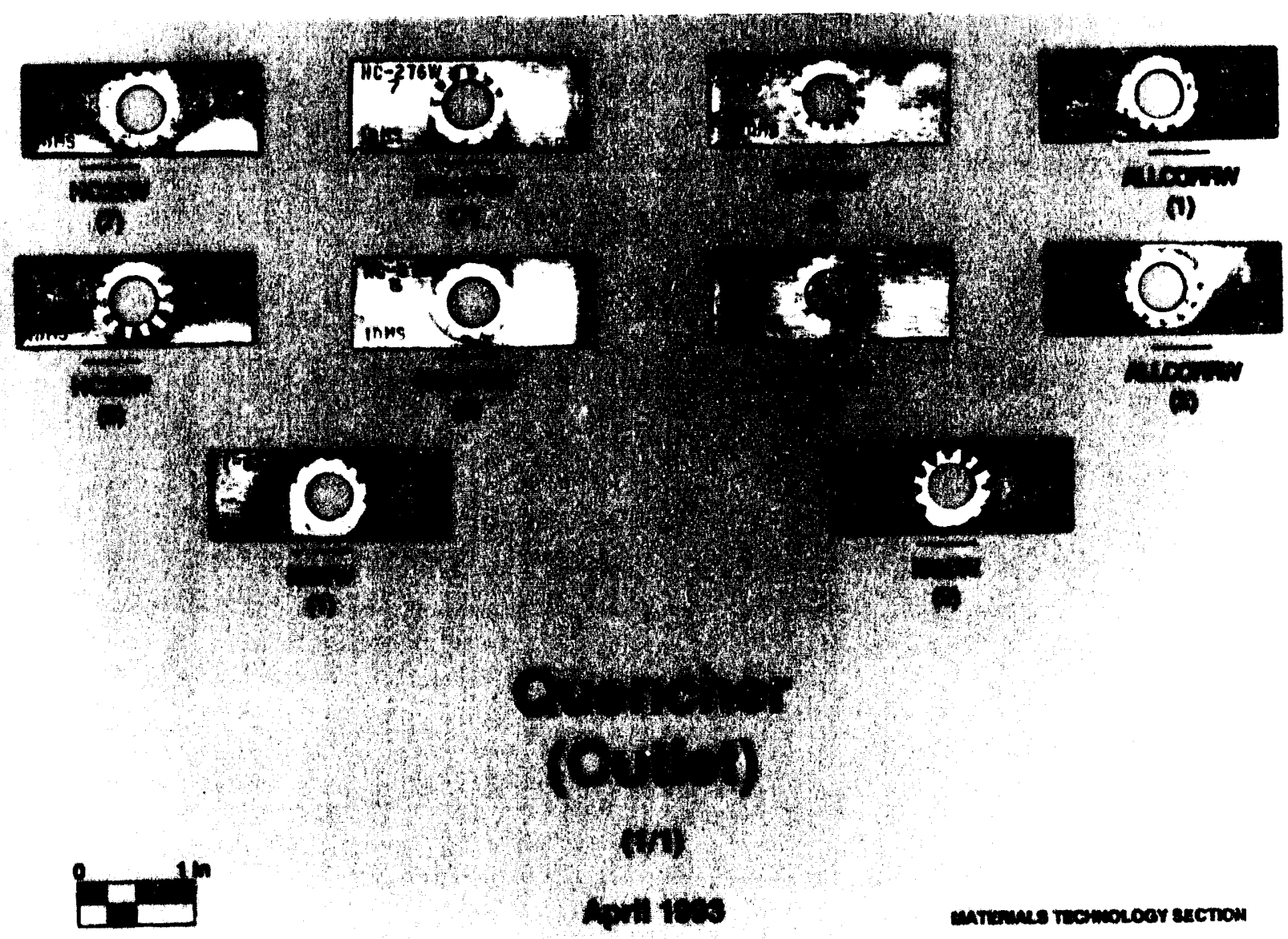


J. R. Zamecnik, 704-T

September 16, 1993

Page 49 of 65

WSRC-TR-93-461

\section{FIGURE 24}

Off-Gas Condensate Tank Vapor space Corrosion Coupons

Photograph Prior To Cleaning* (Negative No. EE52534-A) and schematic showing Location of Coupons on Rack

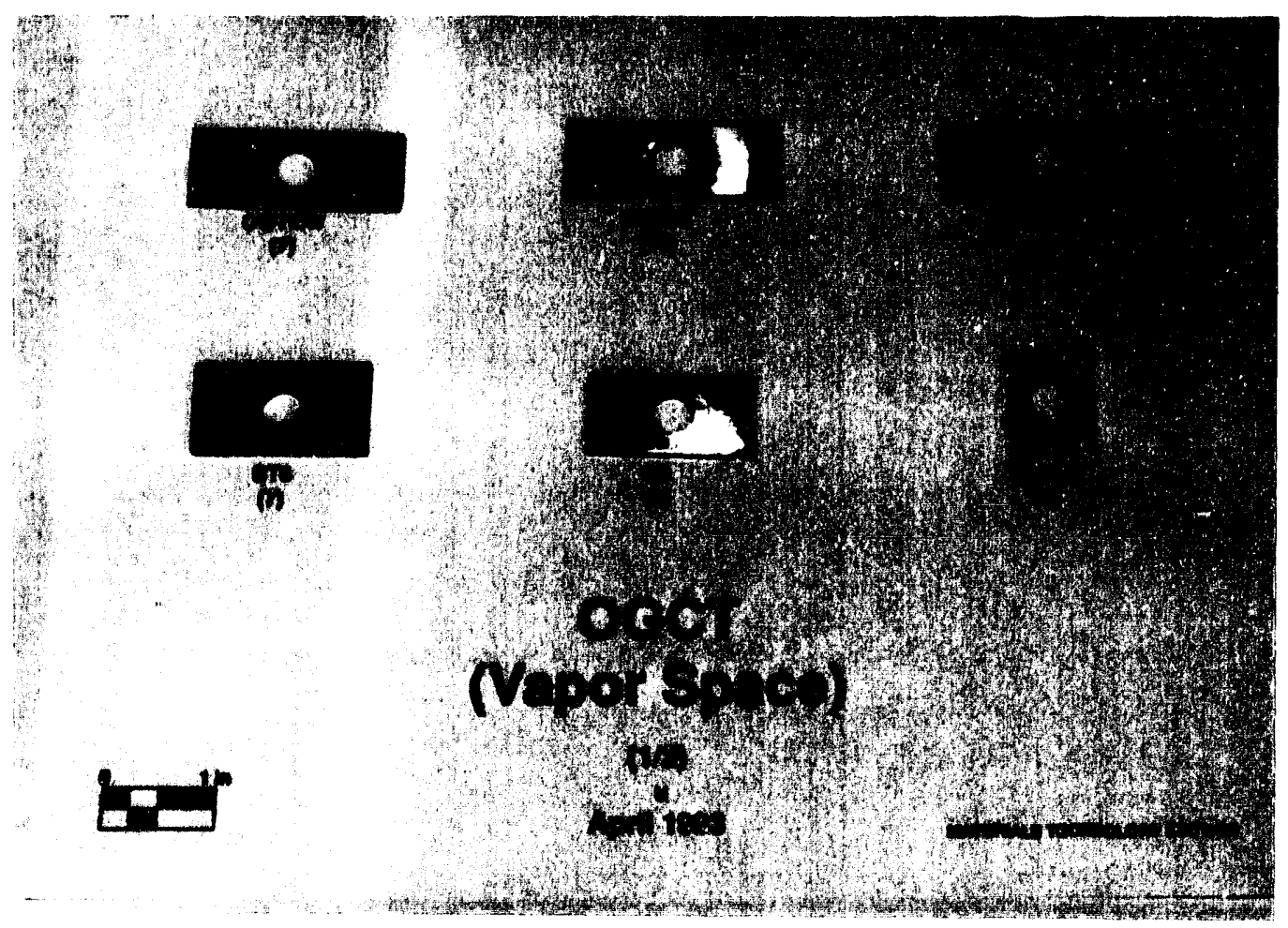

* Rack had to be reinstalled immediately after coupons were removed so photographs of the coupons on the rack were not taken.

VAPDR

(TOP)
LIQUID

(BDTTOM)

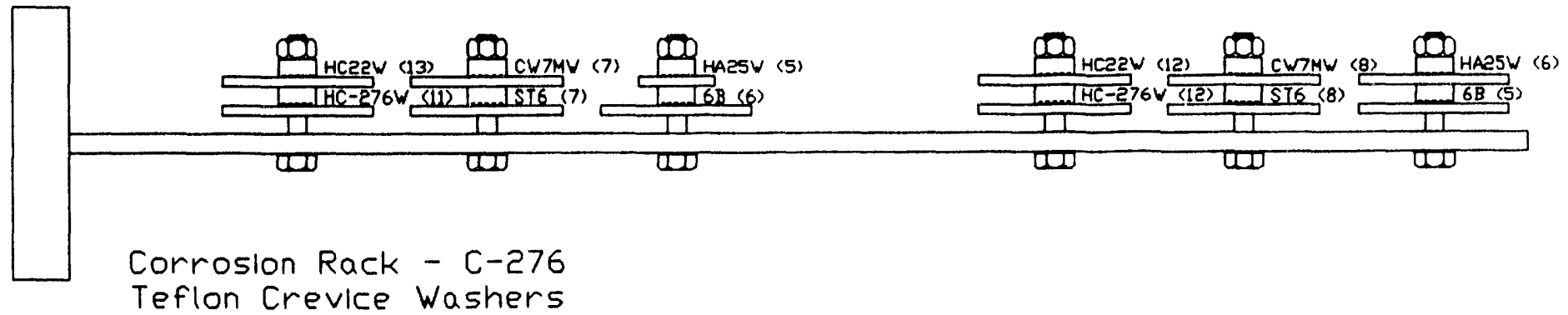


J. R. Zamecnik, 704-T

September 16,1993

Page 50 of 65

WSRC-TR-93-461

FIGURE 25

off-Gas Condensate Tank Iiquid zone Corrosion Coupons

Photograph Prior To Cleaning* (Negative No. EE52534-A) and schematic showing Location of Coupons on Rack
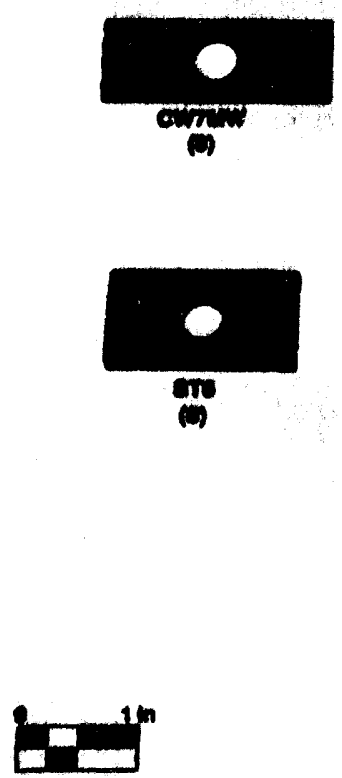
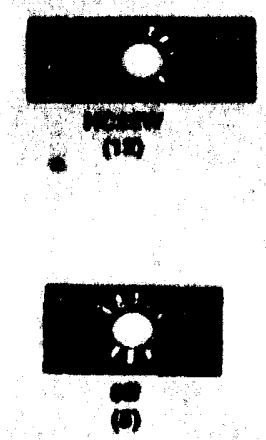

OCCT

(Liquild Zone)

(er)
un
April 1908
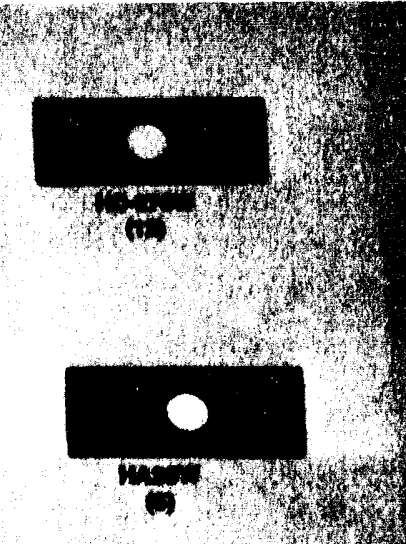

in

* Rack had to be reinstalled immediately after coupons were removed so photographs of the coupons on the rack were not taken.

VAPDR

$(T \square P)$
LIQUID

(BDTTOM)

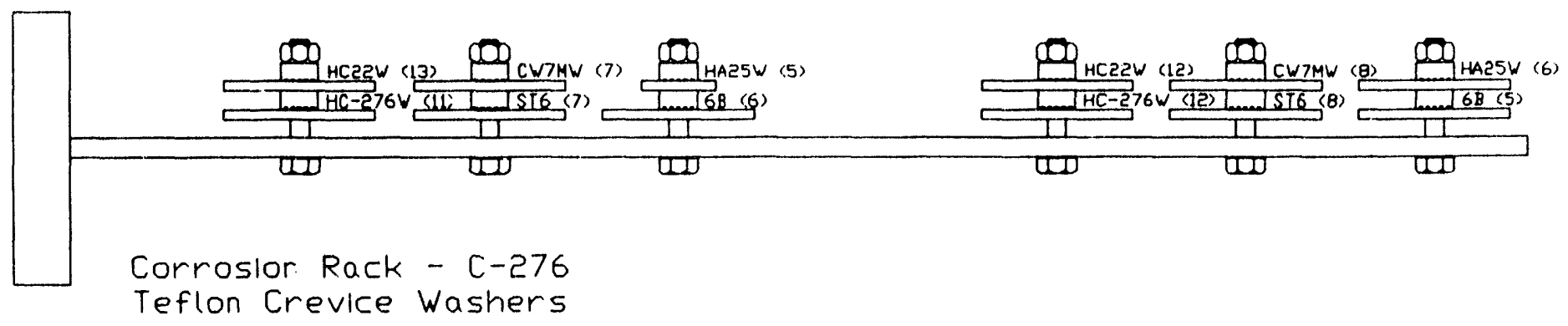


J. R. Zamecnik, 704-T

September 16, 1993

Page 51 of 65

WSRC-TR-93-461

FIGURE 26

off-Gas condensate Tank corrosion Coupons Vapor space And Liquid zone

Photograph Following cleaning with soap And water (Negative No. EE52535-A)

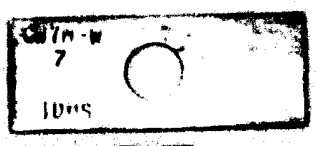

conive

(1)

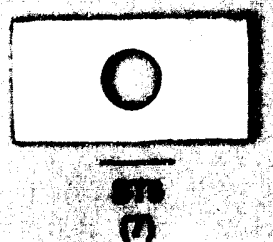

(n)

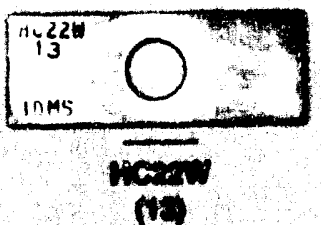

(ia.

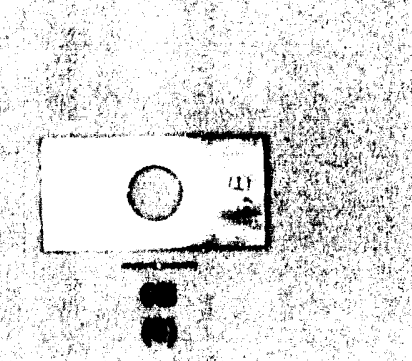

OCCT

(Vapor Space)

(1/2)

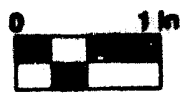

Aprll 1903

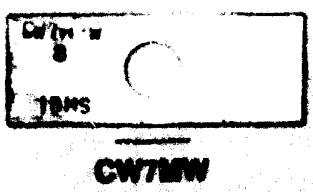

ivi

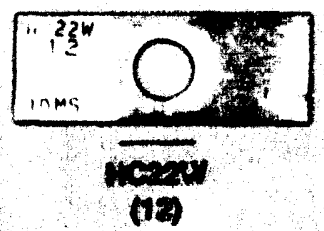

(12)

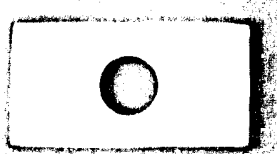

SII.

(i)

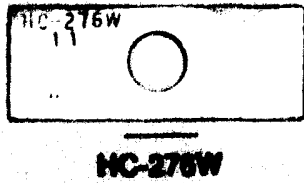

(ii)

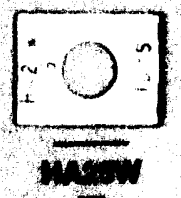

a

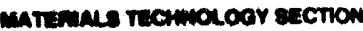

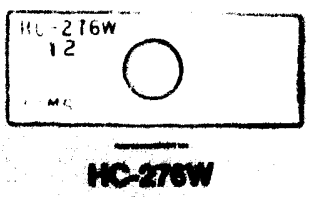

(17)

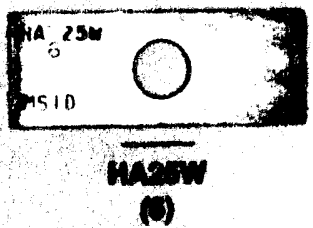

\section{OGCT \\ (Liquid Zone)}

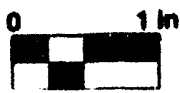

(2/2) 
J. R. Zamecnik, 704-T

September 16, 1993

Page 52 of 65

WSRC-TR-93-461

FIGURE 27

Off-Gas Condenser vapor Inlet Corrosion coupon Rack*

Photograph Prior To Cleaning (Negative No. EE52534-A) and schematic showing Location of Coupons on Rack

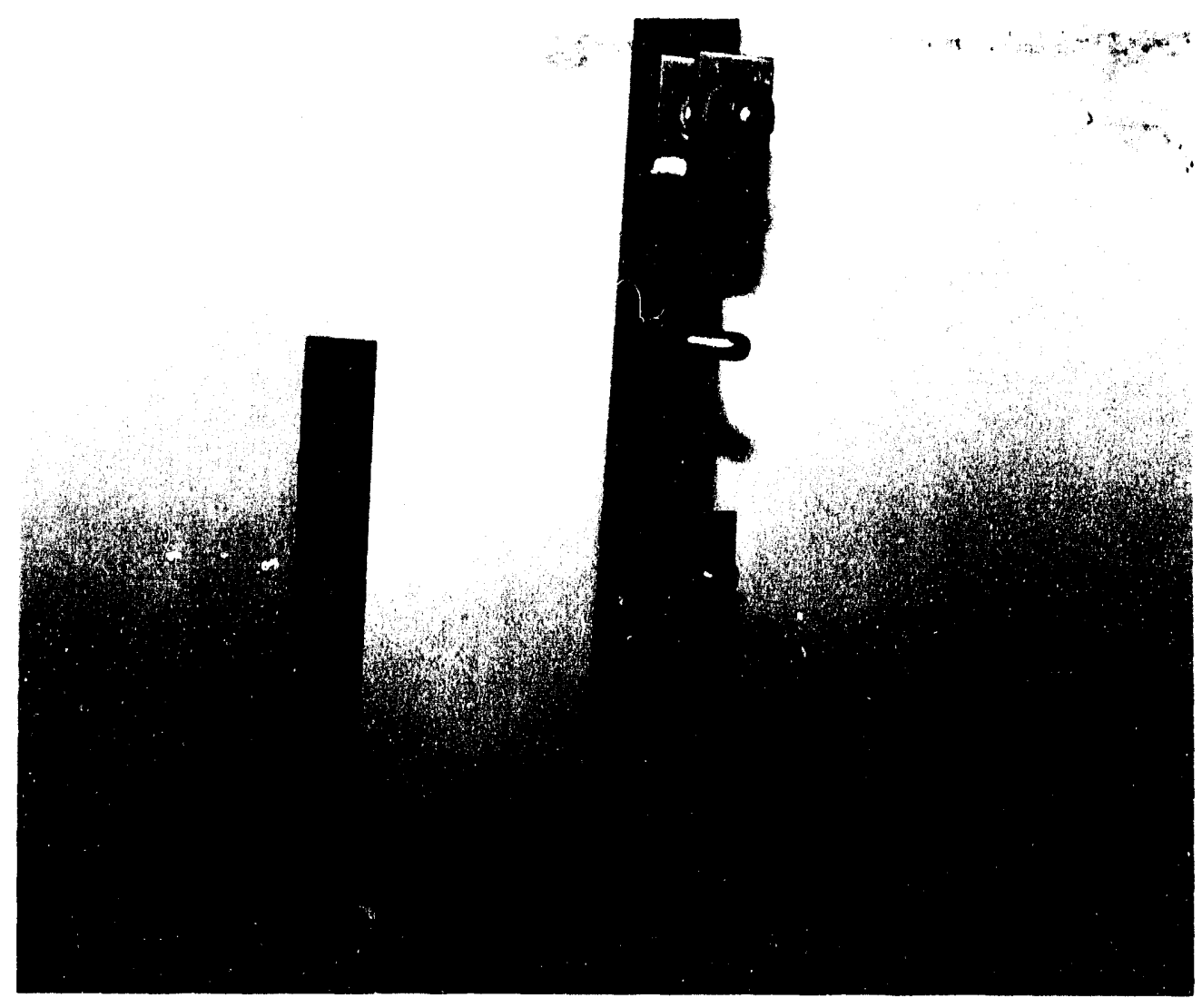

* Photograph is mislabeled should be off-Gas condenser Vapor Inlet

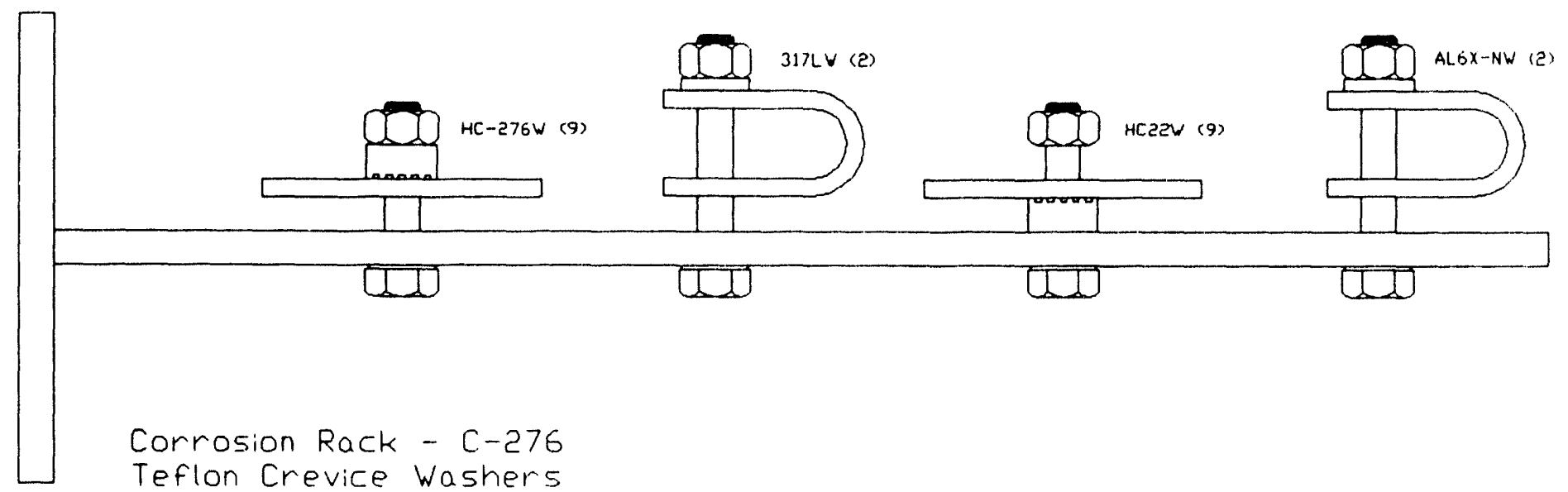


J. R. Zamecnik, 704-T

September 16, 1993

Page 53 of 65

WSRC-TR-93-461

FIGURE 28

off-Gas Condenser vapor Inlet corrosion ce spons

Photograph Following cleaning with soap and water

(Negative No. EE52535-A)

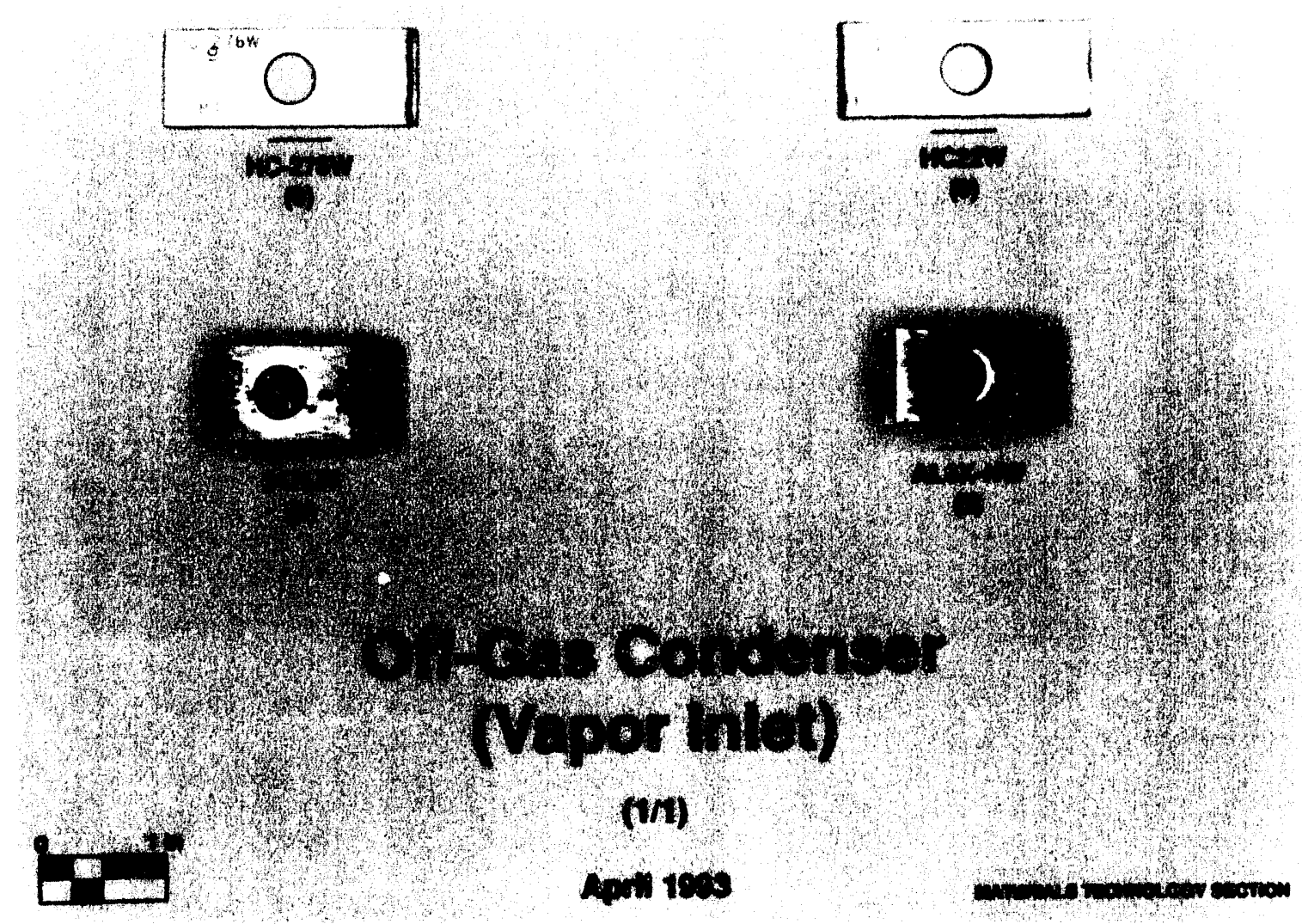


J. R. Zamecnik, $70 \hat{4}-\mathrm{T}$

September 16, 1993

Page 54 of 65

WSRC-TR-93-461

FIGURE 29 a And b

off-Gas condenser Vapor Inlet

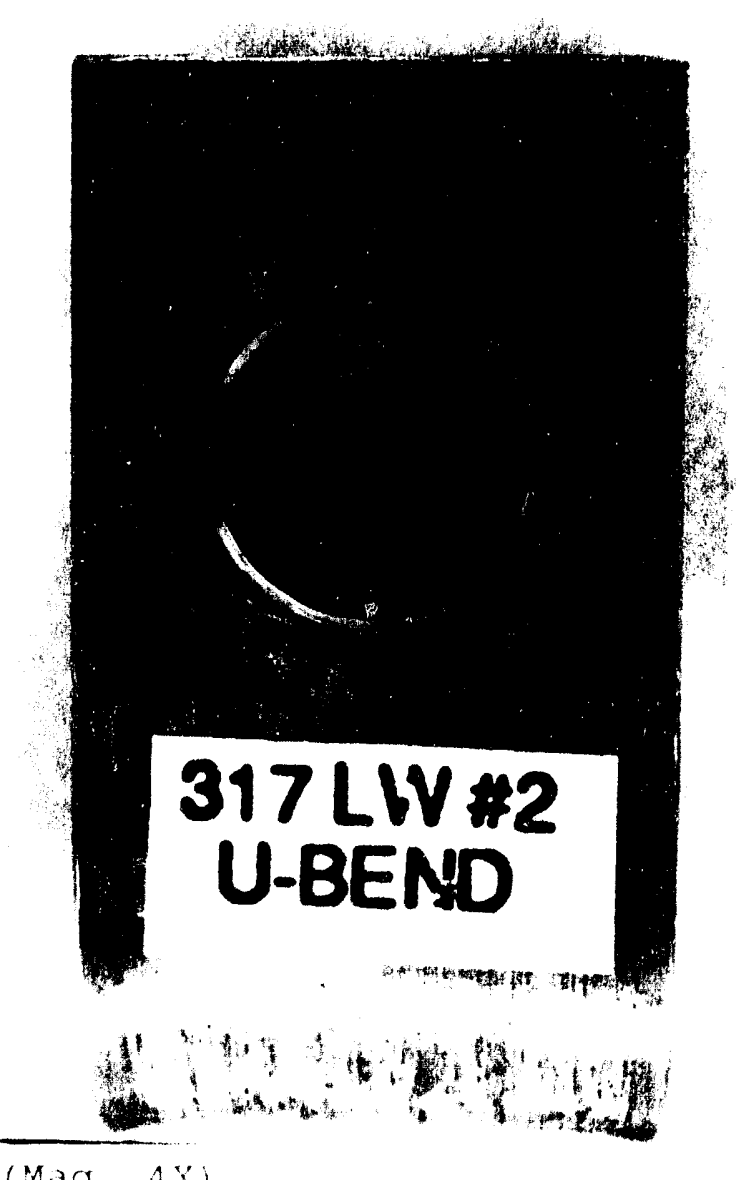

$(\mathrm{Mag} \cdot 4 \%)$

Figure 29a. Photograph of l:bend corrosion coupon 317 Liv (1) showing pitting attact under Teflon washer. Pits were not observed in any other reyion. (Nogative No. EE52531-A).

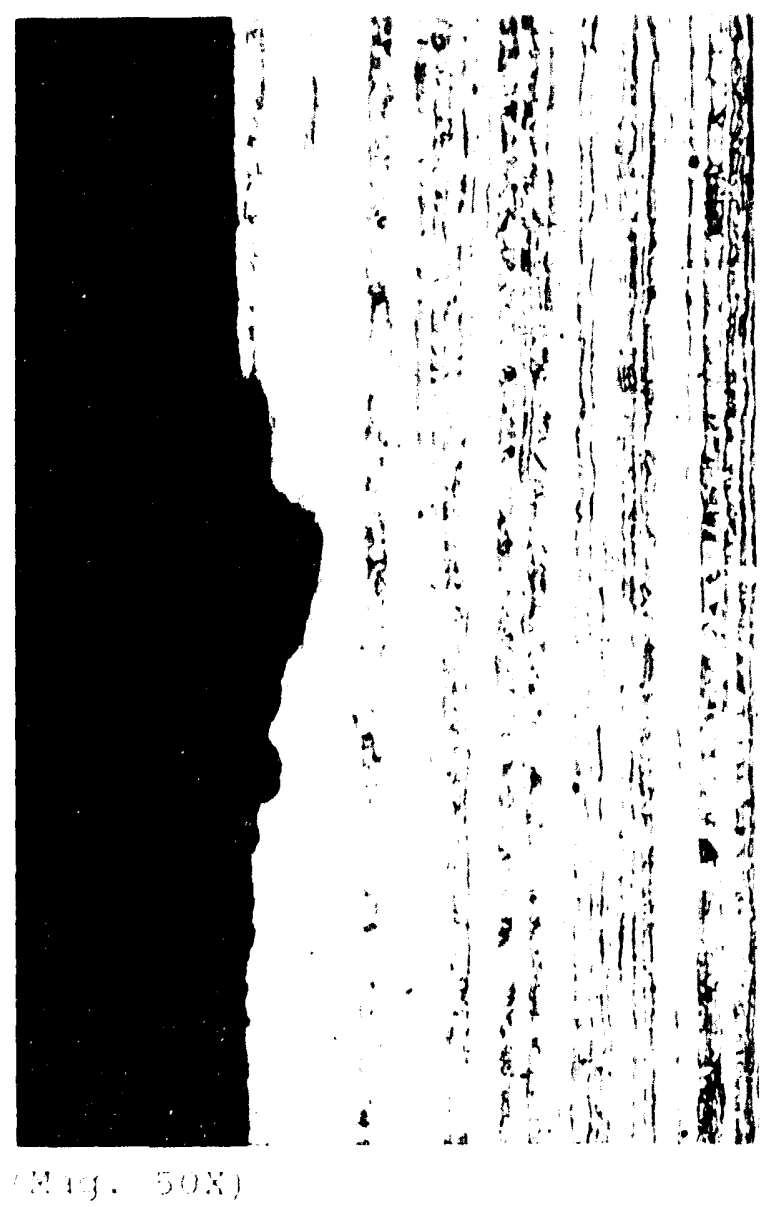

Figure ayb photomicrograph oi it trom l-bend corrosion

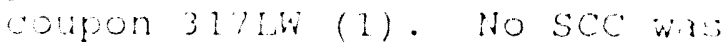
cherrod. (Regative no. (E) $(2,3 ?-A)$. 
J. R. Zamecnik, 704-T

September 16,1993

Page 55 of 65

WSRC-TR-93-461

FIGURE 30

Off-Gas Condenser Drain Corrosion Coupon Rack

Photograph Prior To Cleaning (Negative No. EE52534-A) and schematic showing Location of Coupons on Rack
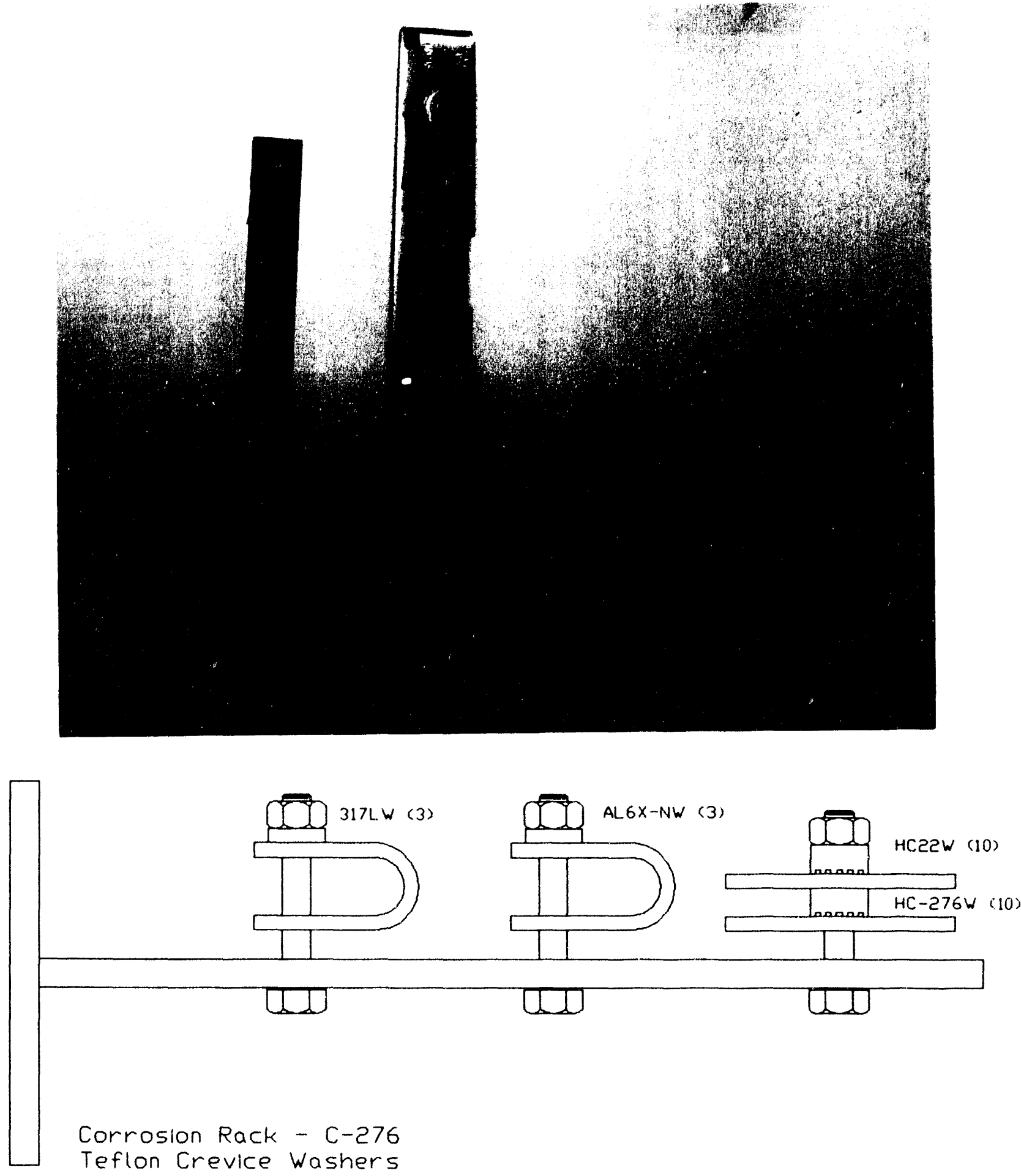
J. R. Zamecnik, 704-T

September 16, 1993

Page 56 of 65

WSRC-TR-93-461

FIGURE 31

off-Gas Condenser Drain Corrosion Coupons

Photograph Following cleaning with soap and water (Negative No. EE52535-A)

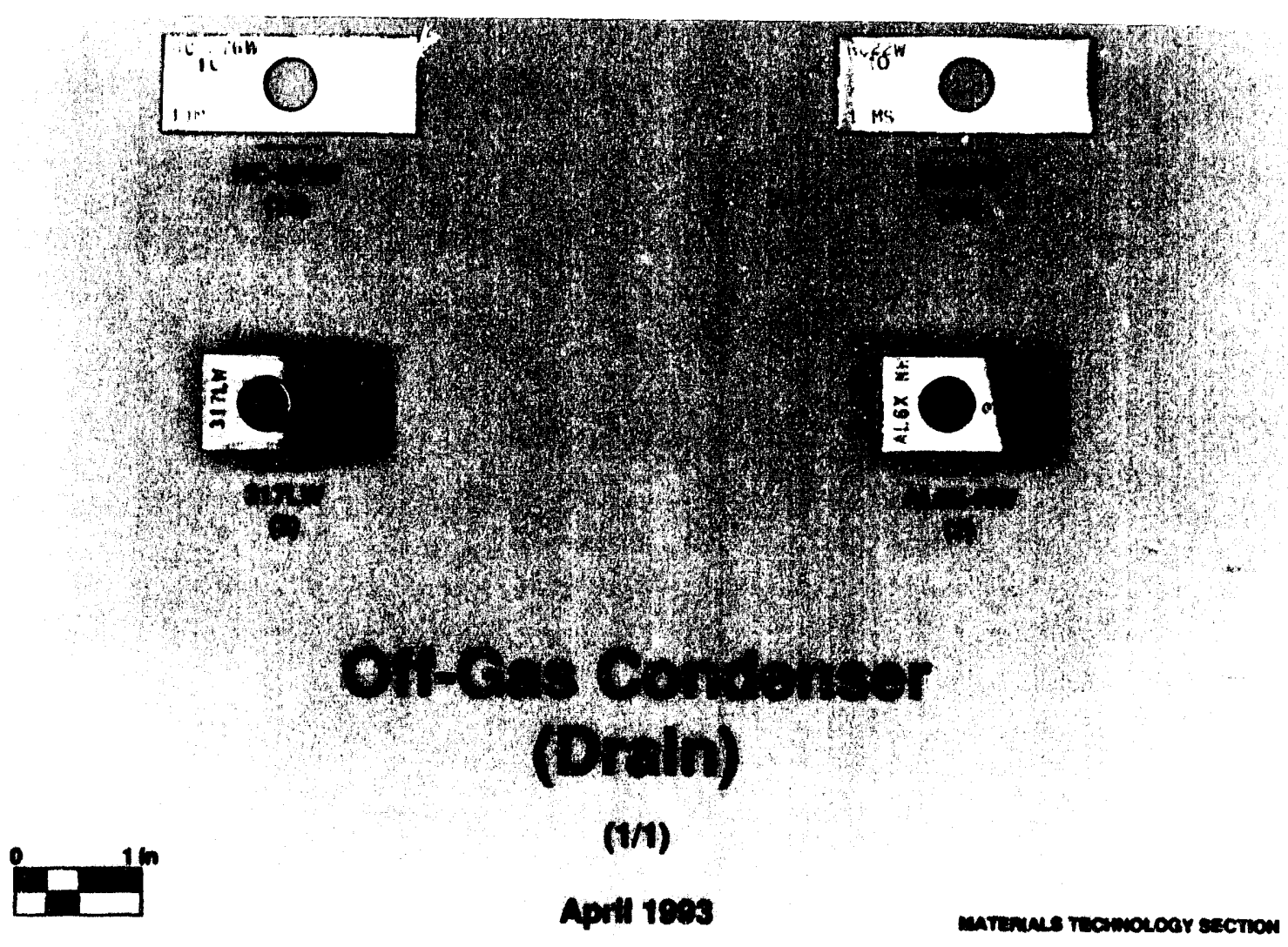


J. R. Zamecnik, 704-T

September 16,1993

Page 57 of 65

WSRC-TR-93-461

\section{FIGURE 32}

8team Atomized 8crubber Drain Line Corrosion Coupon Rack

Photograph Prior To Cleaning (Negative No. EE52534-A) and schematic showing Location of Coupons on Rack
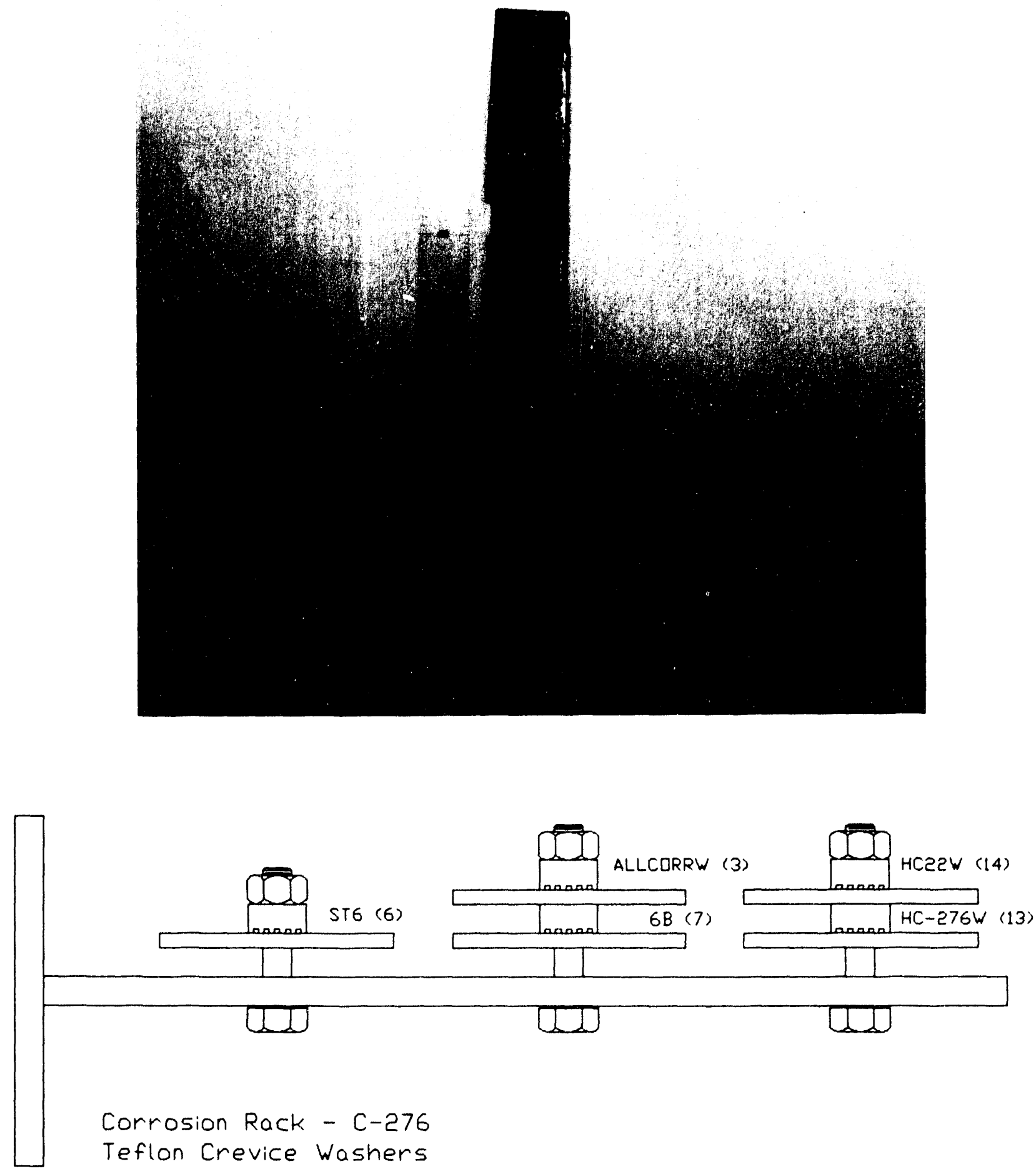
J. R. Zamecnik, 704-T

September 16,1993

Page 58 of 65

WSRC-TR-93-461

FIGURE 33

steam Atomized scrubber Drain Line Corrosion Coupons Photograph Following cleaning with soap and water (Negative No. EE52535-A)

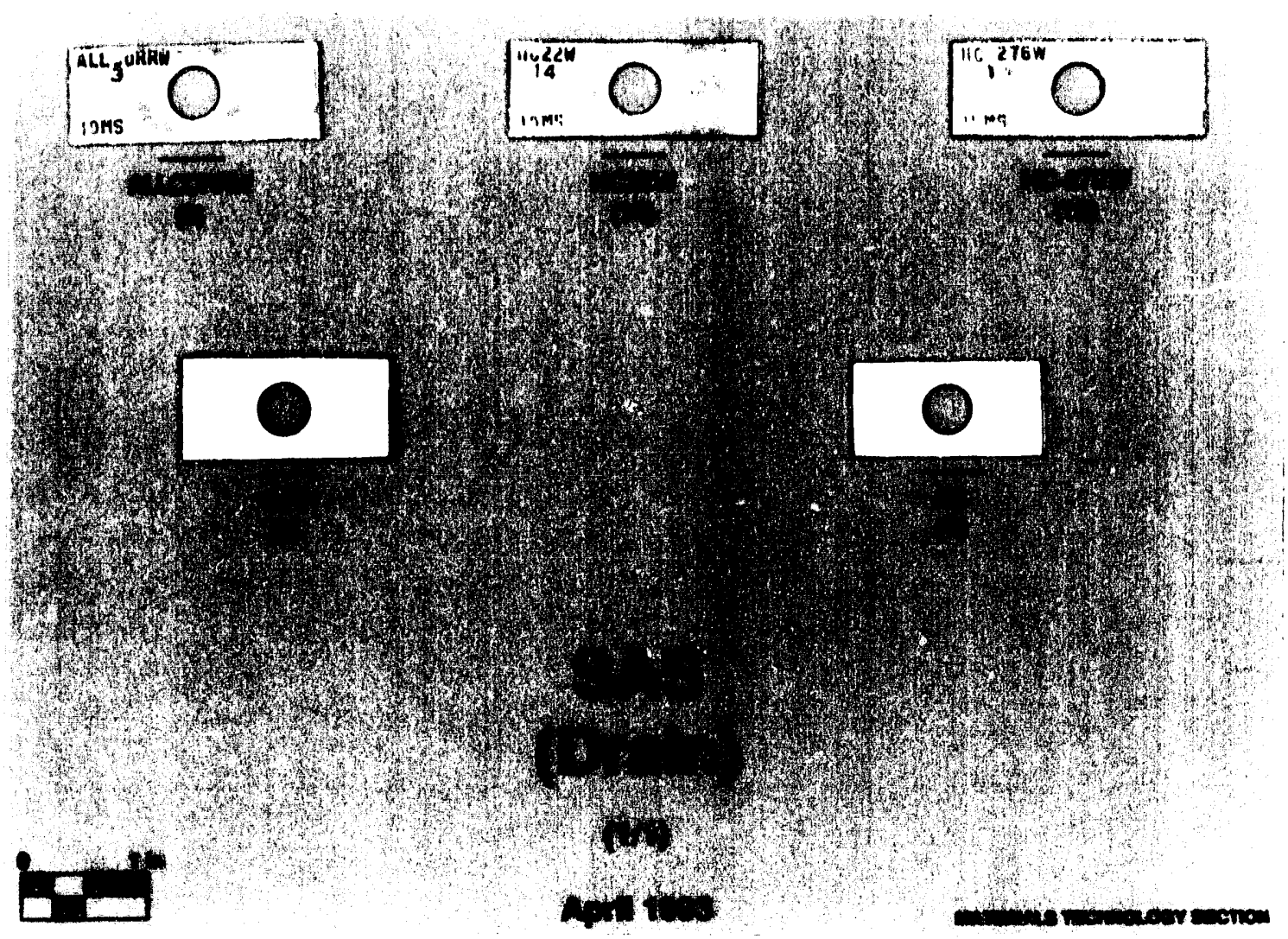


J. R. Zamecnik, 704-T

September 16,1993

Page 59 of 65

WSRC-TR-93-461

FIGURE 34

HEME Inlet corrosion Coupon Rack

Photograph Prior To Cleaning (Negative No. EE52534-A) and schematic showing Location of Coupons on Rack
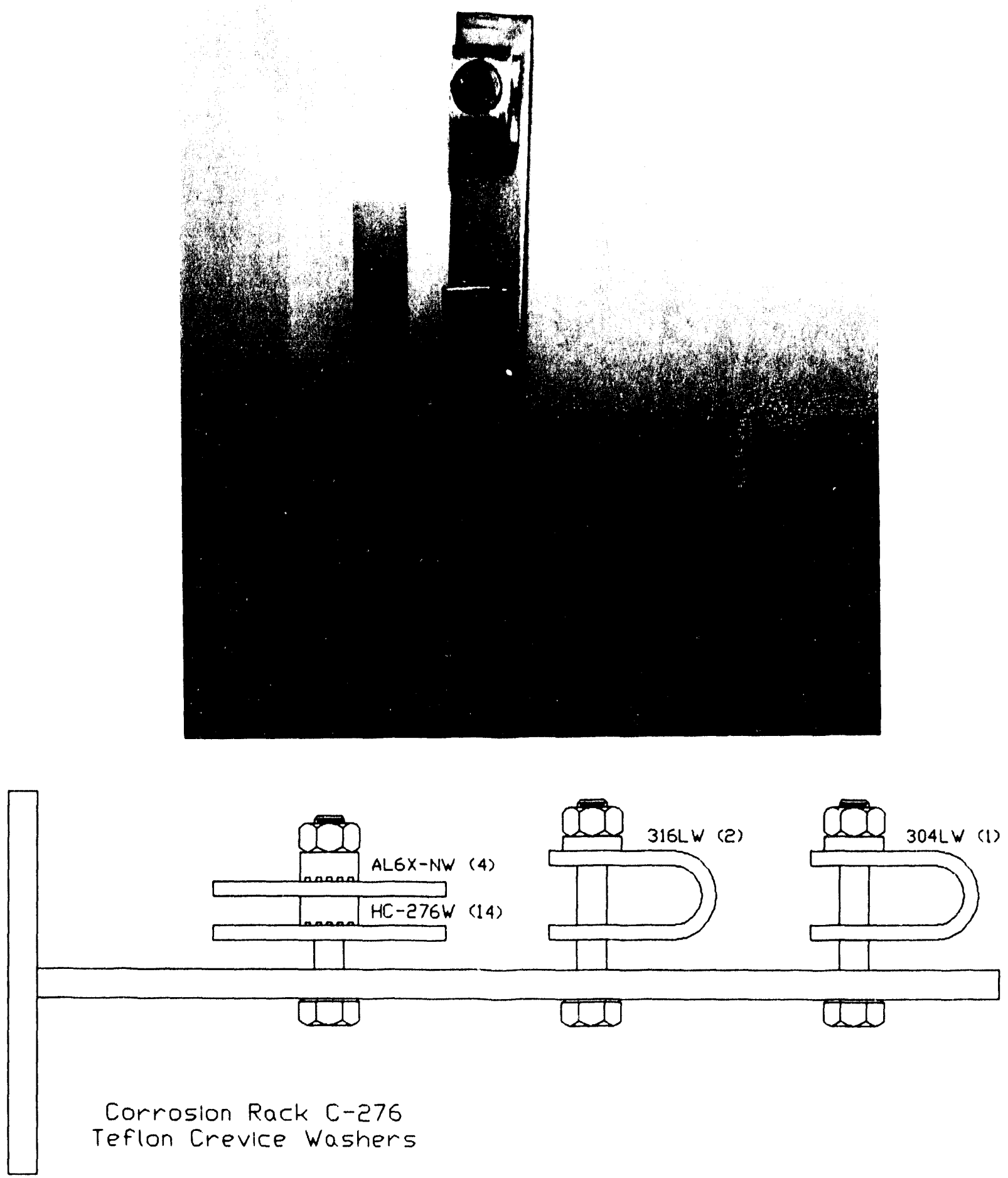
J. R. Zamecnik, 704-T

September 16, 1993

Page 60 of 65

WSRC-TR-93-461

\section{FIGURE 35}

\section{HEME Inlet corrosion coupons}

\section{Photograph Following cleaning with soap And watex (Negative No. EE52535-A)}

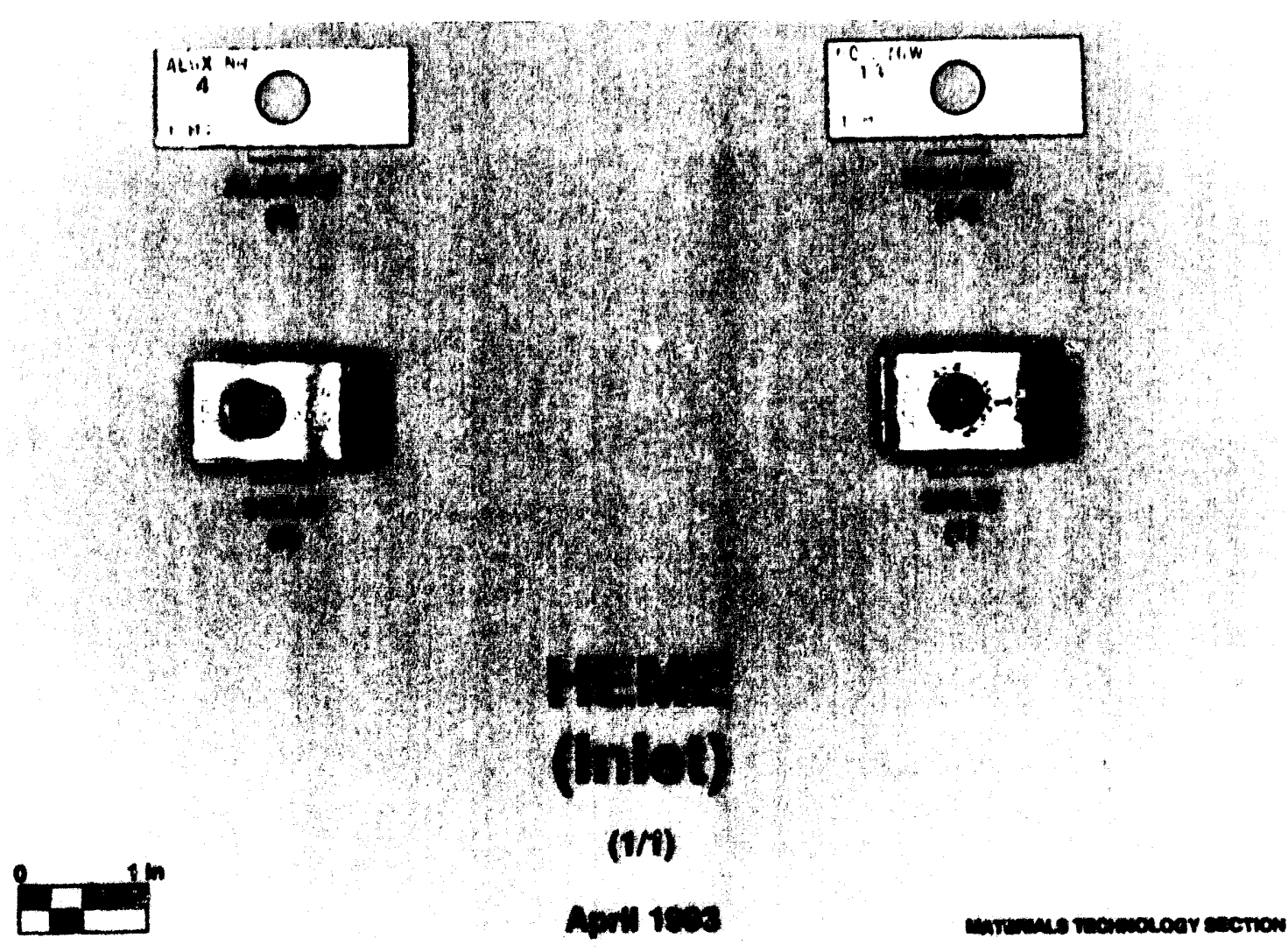


J. R. Zamecnik, 704-T

September 16, 1993

Page 61 of 65

WSRC-TR-93-461

FIGURES $36 a \& b$

HEME Inlet

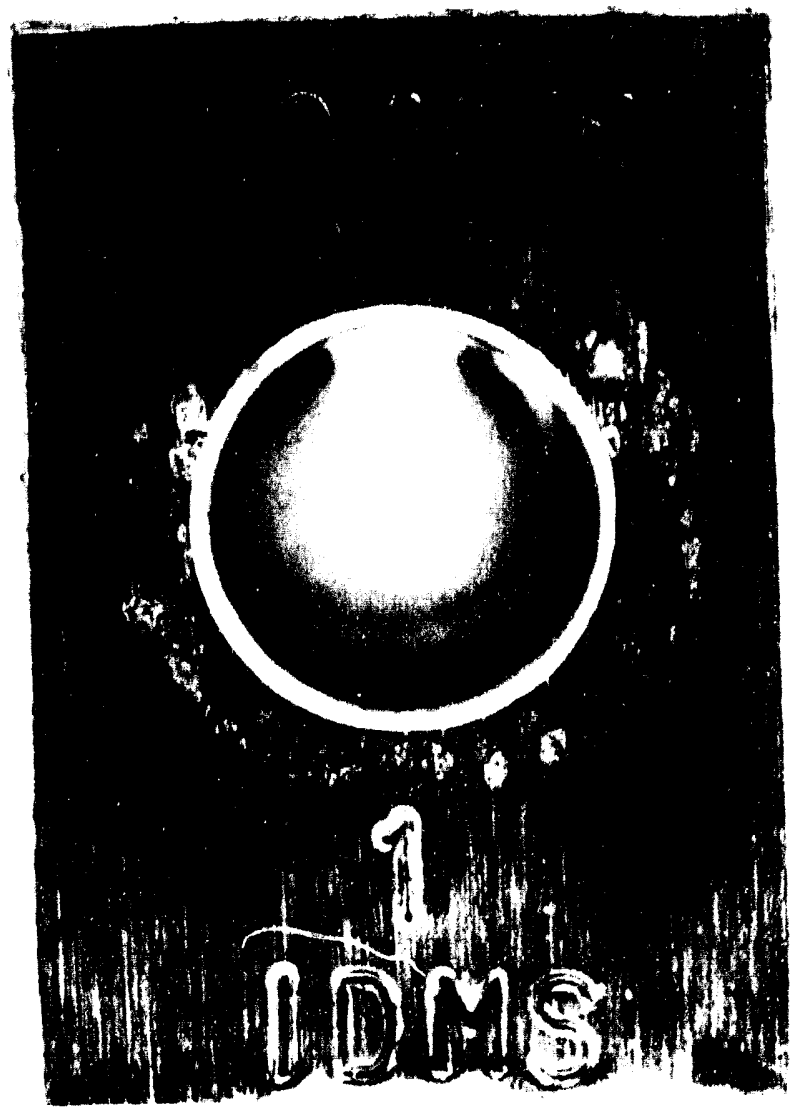

(Mag. 4X)

Figure 36a. Photograph of Ubend corrosion coupon $304 \mathrm{LW}$ (1) from HEME Inlet showing pitting attack under Teflon washer. Pits were not observed in any other region. (Negative No. EE52531-A).

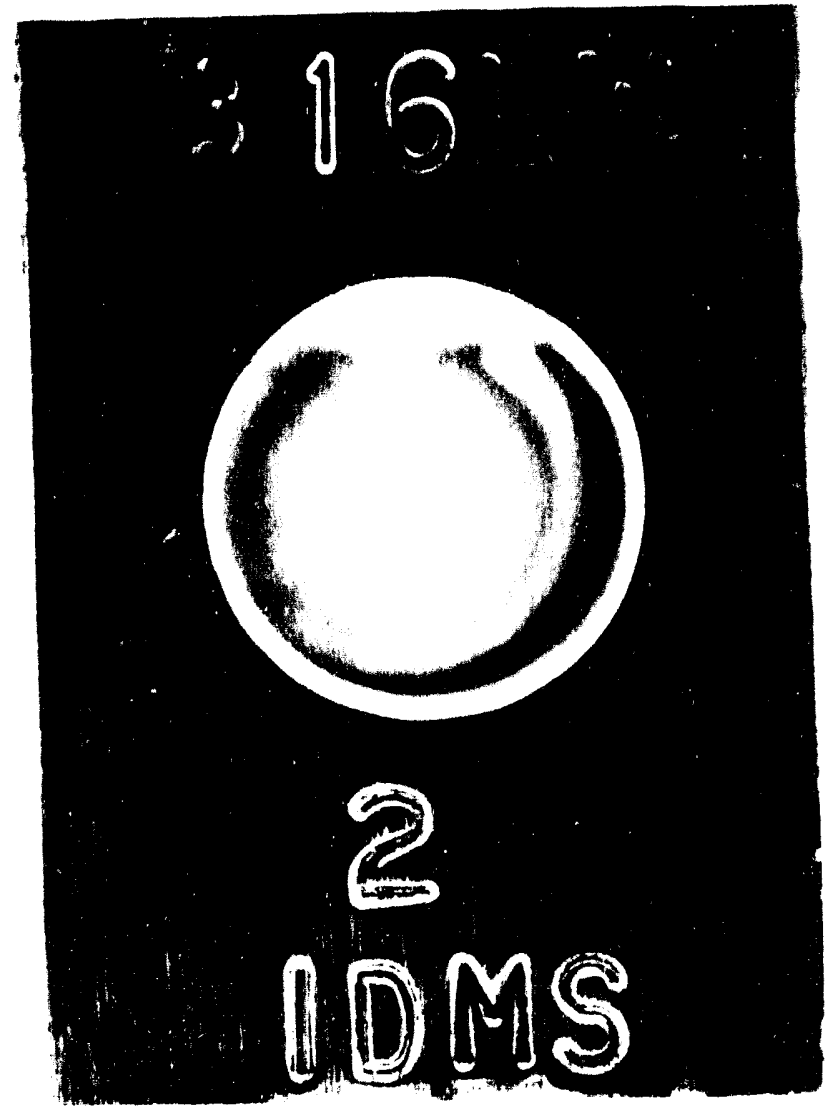

(Mag. 4X)

Figure $36 \mathrm{~b}$. Photograph of Ubend corrosion coupon $316 \mathrm{LW}$ (1) from HEME Inlet showing pitting attack under Teflon washer. Pits were not observed in any other region. (Negative No. EE52530-A). 
J. R. Zamecnik, 704-T

September 16, 1993

Page 62 of 65

WSRC-TR-93-461

FIGURE 37

HEME outlet corrosion Coupon Rack

Photograph Prior To cleaning (Negative No. EE52534-A) and schematic showing Location of Coupons on Rack

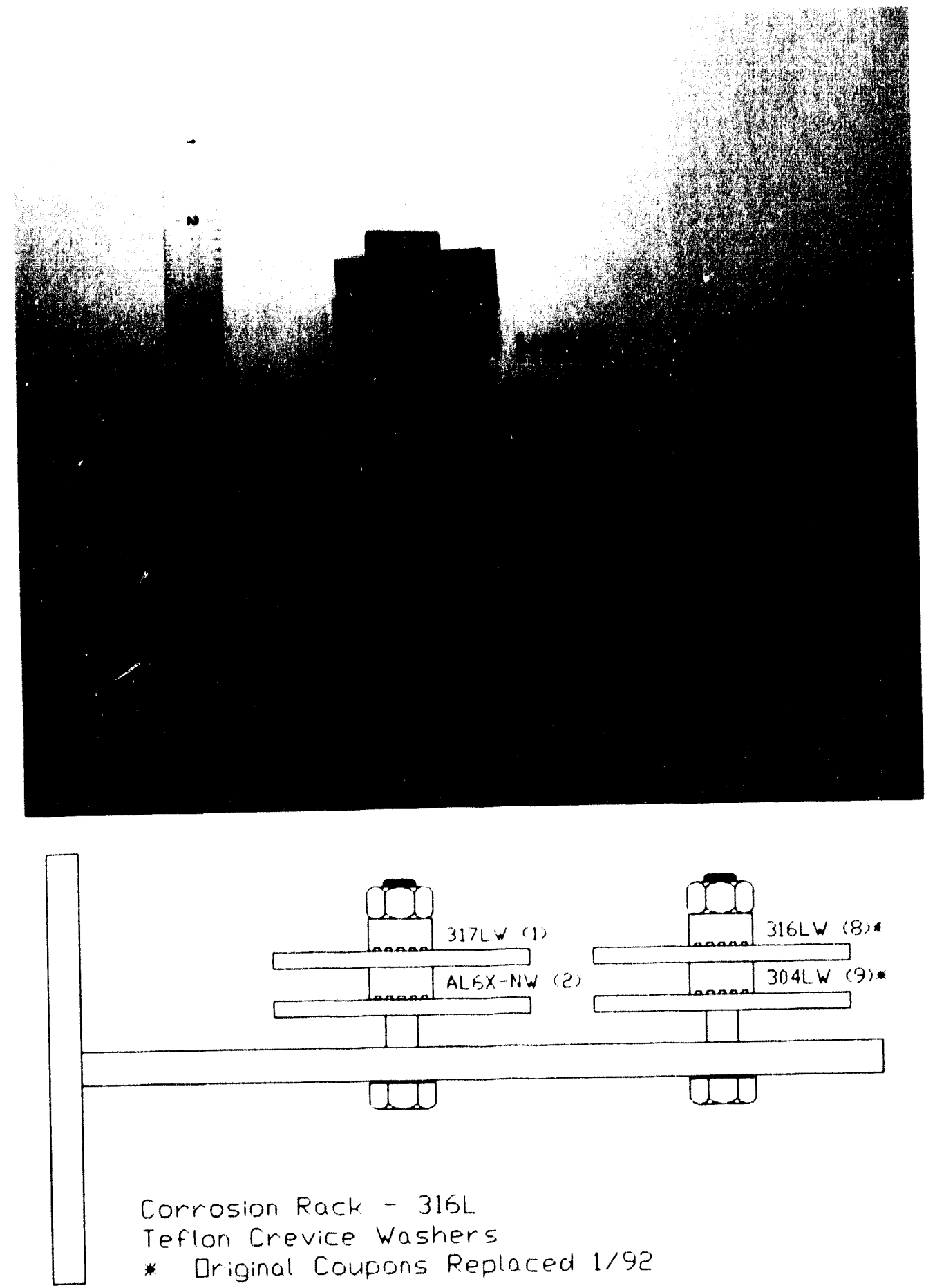


J. R. Zamecnik, 704-T

September 16,1993

Page 63 of 65

WSRC-TR-93-461

FIGURE 38

HEME outlet Corrosion coupons

\section{Photograph Following cleaning with soap and water (Negative No. EE52535-A)}

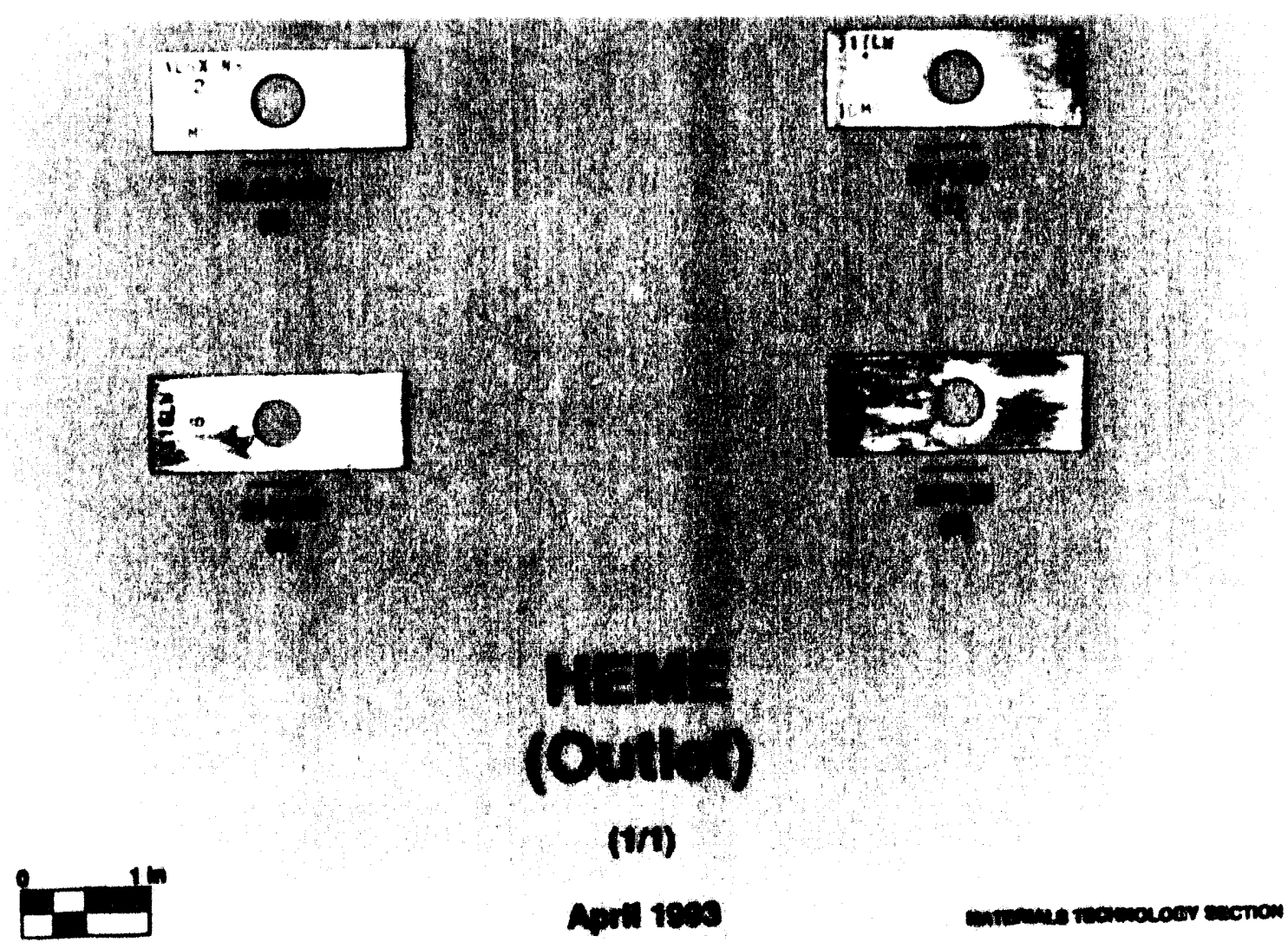


J. R. Zamecnik, 704-T

September 16, 1993

Page 64 of 65

WSRC-TR-93-461

FIGURE 39

HEPA Inlet Corrosion Coupon Rack

Photograph Prior To Cleaning (Negative No. ER52534-A) and schematic showing Location of Coupons on Rack
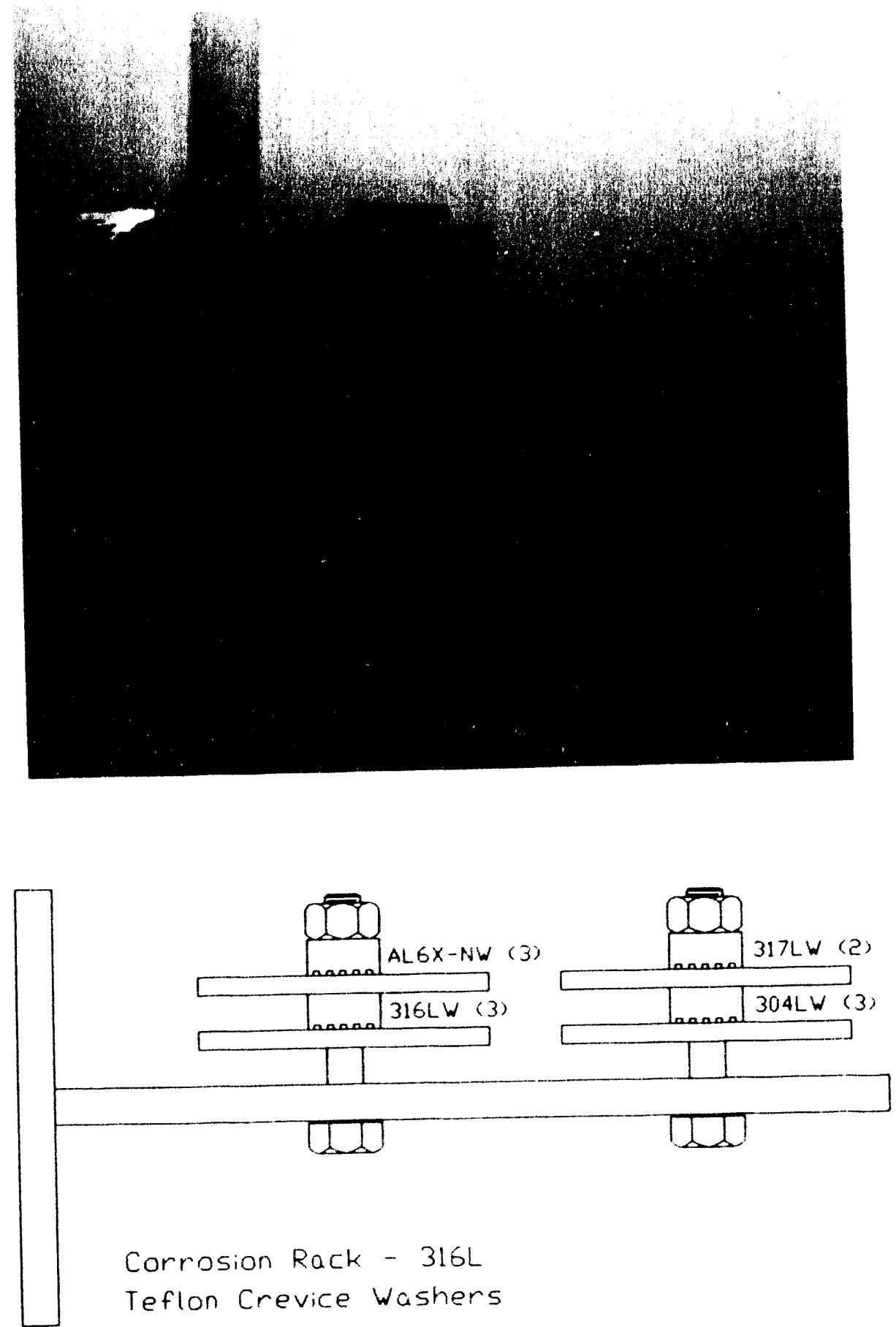
J. R. Zamecnik, 704-T

September 16, 1993

Page 65 of 65

WSRC-TR-93-461

FIGURE 40

HEPA Inlet corrosion coupons

Photograph Following Cleaning with soap And water (Negative No. EE52535-A)

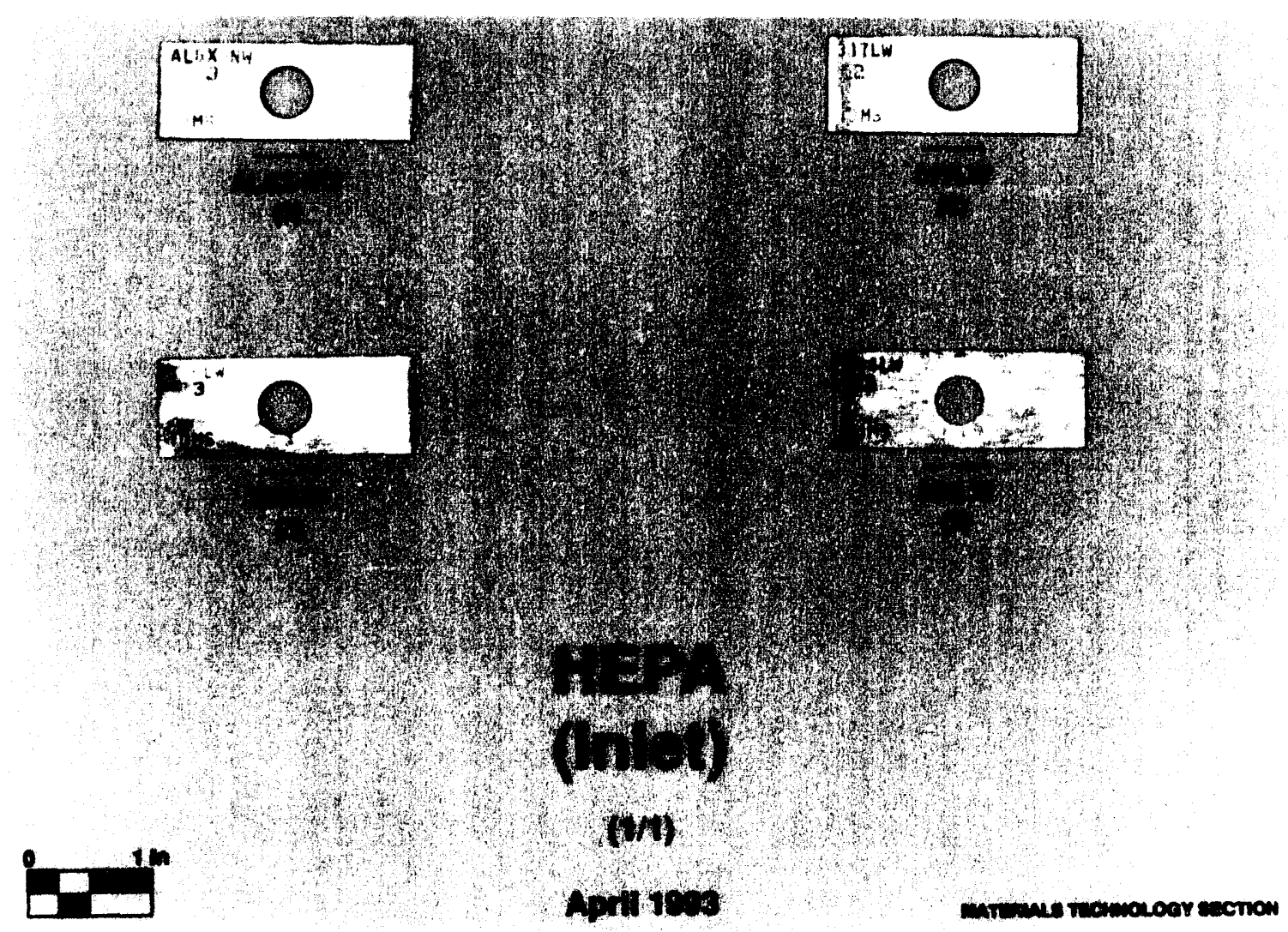



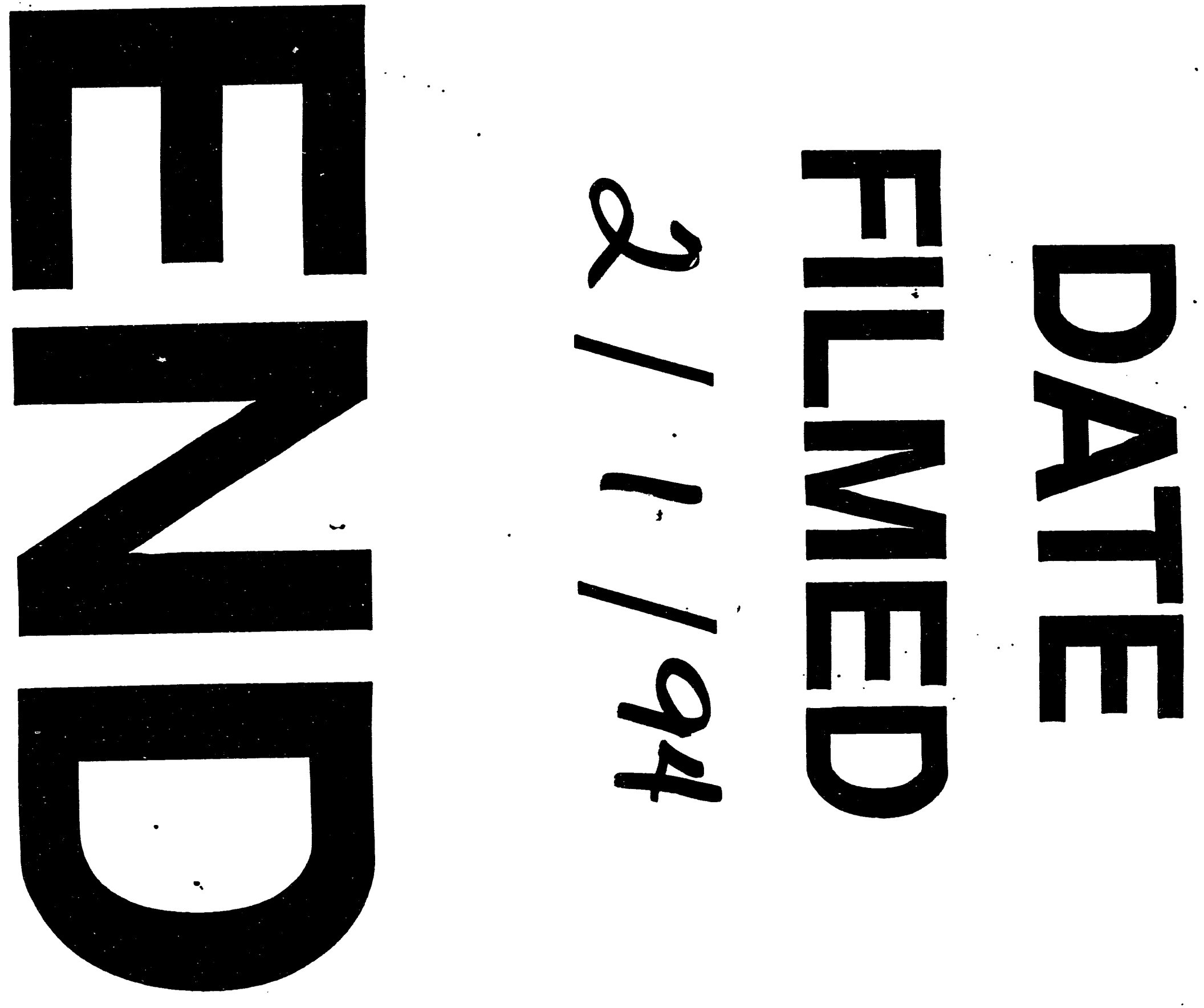
